\title{
Nutraceutical, Dietary, and Lifestyle Options for Prevention and Treatment of Ventricular Hypertrophy and Heart Failure
}

\author{
Mark F. McCarty
}

check for updates

Citation: McCarty, M.F.

Nutraceutical, Dietary, and Lifestyle Options for Prevention and Treatment of Ventricular Hypertrophy and Heart Failure. Int. J. Mol. Sci. 2021, 22, 3321. https://doi.org/10.3390/ ijms22073321

Academic Editor: Mathias Mericskay

Received: 1 March 2021

Accepted: 22 March 2021

Published: 24 March 2021

Publisher's Note: MDPI stays neutral with regard to jurisdictional claims in published maps and institutional affiliations.

Copyright: (C) 2021 by the author. Licensee MDPI, Basel, Switzerland. This article is an open access article distributed under the terms and conditions of the Creative Commons Attribution (CC BY) license (https:// creativecommons.org/licenses/by/ $4.0 /)$.
Catalytic Longevity Foundation, 811 B Nahant Ct., San Diego, CA 92109, USA; markfmccarty@gmail.com
Abstract: Although well documented drug therapies are available for the management of ventricular hypertrophy $(\mathrm{VH})$ and heart failure (HF), most patients nonetheless experience a downhill course, and further therapeutic measures are needed. Nutraceutical, dietary, and lifestyle measures may have particular merit in this regard, as they are currently available, relatively safe and inexpensive, and can lend themselves to primary prevention as well. A consideration of the pathogenic mechanisms underlying the $\mathrm{VH} / \mathrm{HF}$ syndrome suggests that measures which control oxidative and endoplasmic reticulum (ER) stress, that support effective nitric oxide and hydrogen sulfide bioactivity, that prevent a reduction in cardiomyocyte $\mathrm{pH}$, and that boost the production of protective hormones, such as fibroblast growth factor 21 (FGF21), while suppressing fibroblast growth factor 23 (FGF23) and marinobufagenin, may have utility for preventing and controlling this syndrome. Agents considered in this essay include phycocyanobilin, N-acetylcysteine, lipoic acid, ferulic acid, zinc, selenium, ubiquinol, astaxanthin, melatonin, tauroursodeoxycholic acid, berberine, citrulline, high-dose folate, cocoa flavanols, hawthorn extract, dietary nitrate, high-dose biotin, soy isoflavones, taurine, carnitine, magnesium orotate, EPA-rich fish oil, glycine, and copper. The potential advantages of wholefood plant-based diets, moderation in salt intake, avoidance of phosphate additives, and regular exercise training and sauna sessions are also discussed. There should be considerable scope for the development of functional foods and supplements which make it more convenient and affordable for patients to consume complementary combinations of the agents discussed here. Research Strategy: Key word searching of PubMed was employed to locate the research papers whose findings are cited in this essay.

Keywords: ventricular hypertrophy; congestive heart failure; nutraceuticals; nitric oxide; hydrogen sulfide; ER stress; FGF21; FGF23; marinobufagenin; plant-based diets

\section{Sketch of the Pathogenesis of Ventricular Hypertrophy and Heart Failure}

Ventricular hypertrophy $(\mathrm{VH})$ progressing to heart failure $(\mathrm{HF})$ is considered the leading cause of death in the U.S. today. This reflects the fact that such common cardiovascular disorders as coronary atherosclerosis, myocardial infarction, hypertension, chronic renal failure, diabetes, and obesity play a role in its induction. In this disorder, cardiomyocytes are subjected to chronically elevated oxidative stress, as well as a dysregulation of calcium control in which: calcium influx is inappropriately upregulated in some microenvironments. This intracellular calcium dysregulation leads to chronic activation of the key mediators calcineurin, nuclear factor of activated T cells (NFAT) and calcium/calmodulin-dependent protein kinase II (CaMKII), drivers of cardiomyocyte hypertrophy. It also compromises the swift systolic rise and rapid diastolic rise of intracellular free calcium, leading to decreased efficiency of contraction and relaxation, as well as an increased risk for arrhythmias. Additionally, this is associated with a depletion of calcium in the sarcoplasmic reticulum, giving rise to endoplasmic reticulum (ER) stress, a mediator of the cardiomyocyte apoptosis that contributes to progressive heart failure.

This pathological stew, which is self-reinforcing in many ways, is typically triggered by chronic mechanical strain-induced by uncontrolled hypertension, volume overload, 
valvular stenosis or failure, or loss of viable myocardium following myocardial infarctions or infections-and neurohormonal stimuli associated with the systemic stress reaction and/or kidney failure, such as adrenergic activity, angiotensin II, endothelin, and fibroblast growth factor 23 (FGF23). Other triggering stimuli include obesity/diabetes (associated with excessive exposure of cardiomyocytes to saturated free fatty acids), parathyroid hormone, and the hormone marinobufagenin (produced when salt-sensitive people eat salty diets).

Most of these triggers either activate phospholipase C- $\beta$ (PLC- $\beta$ ) via G $\alpha q$ or boost cAMP production; FGF23 acts via FGFR4 to stimulate PLC- $\gamma$ [1-9]. Mechanical stretch of cardiomyocytes opens pannexin-1 channels, allowing ATP to leak to the extracellular space, where it can activate P2Y purinoreceptors coupled to G $\alpha \mathrm{q}[10,11]$. The centrality of G $\alpha \mathrm{q} / \mathrm{PLC}-\beta$ to the VH/HF syndrome is revealed by the fact that transgenic mice bioengineered to overexpress $\mathrm{G} \alpha \mathrm{q}$ in cardiomyocytes experience $\mathrm{VH}$ [12]. The diacylglycerol generated by activation of either PLC- $\beta$ or PLC $-\gamma$ plays a key mediating role in this syndrome; transgenic mice with cardio-specific overexpression of diacylglycerol kinase are resistant to hypertrophy when challenged with isoproterenol infusions or surgically induced pressure overload (transverse aortic constriction-TAC) [13]. The diacylglycerol generated by PLC activity increases the open probability of TRPC3/TRPC6 channels in caveolar microdomains; this influx somehow has a priming effect on calcium influx through neighboring L-type calcium channels [14-18]. (Generation of inositol-1,4,5-triphosphate via PLC activity has comparatively little impact on calcium release from sarcoplasmic reticulum in cardiomyocytes [2]) This local calcium increase activates the phosphatase calcineurin, likewise localized in caveolae, which can then dephosphorylate the transcription factor NFAT, enabling its migration to the nucleus, where it promotes transcription of genes coding for hypertrophic proteins and cardiac natriuretic peptides $[16,19,20]$. One of the effects of NFAT-driven transcription is an increase in TRPC6 expression, which in turn helps to maintain NFAT activation [21]. The increase in adrenergic activity usually associated with this syndrome exerts its effects via cAMP, which acts via the G-protein exchange factor EPAC to promote chronic activation of CaMKII; other factors promoting this activation include increased calcium influx within microenvironments, as well as oxidative stress, which induces calcium-independent activation of CaMKII via oxidation of methionine groups [22-26]. CaMKII promotes hypertrophy by phosphorylating and thereby inducing the nuclear export of class II histone deacetylases, which impede transcription of key hypertrophic genes [27-29]. CaMKII also promotes diastolic calcium leak from the sarcoplasmic reticulum by phosphorylating ryanodine receptors (RyR2) [30,31]. Additionally, CaMKII activity exerts transcriptional effects which perturb mitochondrial function, increasing mitochondrial inner membrane potential and boosting superoxide production at complex I [32]. Hence, chronic activation of CaMKII is a mediator of the oxidative stress typical of $\mathrm{VH} / \mathrm{HF}$, which in turn maintains the chronic activation of CaMKII in a vicious cycle. CaMKII may also amplify the ability of increased cytoplasmic calcium to induce oxidative stress and apoptosis by boosting activity of the uniporter which enables mitochondrial calcium influx-although this finding has been disputed [33,34].

cAMP also acts via protein kinase A (PKA) to modulate calcium dynamics-increasing the open probabilities of RyR2 and L-type calcium channels (thereby accounting for its positive inotropic effects), while up-regulating activity of the sarcoplasmic reticulum's calcium pump SERCA2 via phosphorylation of the inhibitory protein phospholambam [35-40].

Cardiac mechanical strain also triggers the conversion of cardiac fibroblasts to myofibroblasts, which proliferate and secrete excessive amounts of collagen and other ground substance proteins, giving rise to the cardiac fibrosis and structural stiffness that contributes importantly to inefficient diastolic relaxation. This phenomenon is of key importance to the genesis of heart failure with preserved ejection fraction (HFpEJ), although it is usually also a feature of heart failure with reduced ejection fraction. When cardiomyocytes are subjected to mechanical strain, they synthesize and secrete increased amounts of transforming growth factor- $\beta$ (TGF $\beta$ ) and connective tissue growth factor (CTGF), which provide the 
paracrine stimulus to cardiac fibroblasts, converting them to myofibroblasts. The mechanism whereby mechanical strain induces increased secretion of TGF $\beta / C T G F$ has been partially defined: Strain in cardiomyocytes opens pannexin- 1 channels that release ATP to the extracellular space, where it stimulates P2Y6 receptors to activate $\mathrm{G} \alpha 12 / 13 \mathrm{G}$ proteins; these in turn trigger activation of the $\mathrm{G}$ protein RhoA and its target kinase ROCK, which induce increased synthesis and secretion of TGF $\beta /$ CTGF [10,41-43]. Angiotensin II signaling in cardiomyocytes likewise can activate G $\alpha 12 / 13$ [44]. TGF $\beta$ signaling within cardiac fibroblasts requires hydrogen peroxide production by Nox4, and is suppressed by nitric oxide/cGMP/protein kinase G (PKG) activity [45-48]. PKG-mediated phosphorylation of Smads opposes TGF $\beta$-induced activation of Smad signaling; PKG also acts upstream in the fibrotic process by inhibiting RhoA activation [48-50]. Additionally, activation of ER stress plays a role in driving conversion of TGF $\beta$-stimulated fibroblasts to myofibroblasts [51-54].

Cardiac fibrosis and hypertrophy of cardiomyocytes is commonly associated with capillary rarefication, which promotes regional hypoxia and increases arrhythmic risk; this reflects a failure of angiogenic mechanisms to respond appropriately to the increase in cardiac mass. Although cardiac vascular endothelial growth factor (VEGF) expression is enhanced initially after a chronic increase in cardiac afterload, VEGF levels eventually fall if this overload is maintained, leading to capillary rarefication, cardiac dilatation, and heart failure [55,56].

Loss of nitric oxide synthase (NOS) activity, often reflecting oxidant-mediated uncoupling, is another key feature of the VH/HF syndrome; this loss makes an especially key contribution to the pathogenesis of HFpEF, in which inefficient diastolic relaxation is the key problem [57,58]. Cardiomyocytes express NOS1 and NOS3 constitutively, whereas coronary vascular endothelium expresses NOS3; NOS2 can be induced in the heart via certain pro-inflammatory hormones and bacterial products [59,60]. Most of the protective effects of NO in the heart appear to be mediated by PKG. PKG promotes optimal activity of the SERCA2A calcium pump by phosphorylating its inhibitor phospholamban (as PKA does) [39]. This boost in SERCA2A activity improves diastolic relaxation by inducing a rapid diastolic decline in intracellular free calcium; this also helps prevent ER stress [61]. PKG-mediated phosphorylation of titin and tubulin in the contractile apparatus improve the efficiency of diastolic relaxation (a "lusitropic" effect); this is a key reason why loss of NO bioactivity promotes HFpEF [62-64]. PKG also helps prevent microenvironmental increases in free calcium by conferring an inhibitory phosphorylation on TRPC3/TRPC6 and L-type calcium channels [65-67]. PKG also suppresses the activity of the myocardial $\mathrm{Na}+/ \mathrm{H}+$ exchanger (NHE-1); this exchanger promotes influx of extracellular calcium indirectly by boosting $\mathrm{Na}$ influx, which in turn drives calcium influx via the $\mathrm{Na}+\mathrm{Ca}+2$ exchanger [68]. PKG, via phosphorylation of the G protein RhoA, blunts the ability of mechanical strain to promote cardiomyocyte synthesis and release of TGF $\beta$ and connective tissue growth factor (CTGF), which act in a paracrine manner on cardiac fibroblasts to trigger cardiac fibrosis; loss of effective NO bioactivity thus makes a key contribution to the pathogenesis of HFpEF, both by promotion of cardiac fibrosis and by loss of lusitropic activity $[49,50,69]$. Additionally, $\mathrm{NO}$ is a mediator of the angiogenic response that is needed when the heart tissue hypertrophies; hence, loss of efficient NO production is a cause of capillary rarefaction in VH/HF [70-72]. Finally, efficient NOS3 ("endothelial" NOS) activity in the peripheral vasculature helps control afterload by mediating endothelium-dependent flow-mediated vasodilation - which also aids exercise capacity in heart failure-and moderating systemic blood pressure [73]. Perversely, flow-mediated dilation tends to be impaired in heart failure owing the reduction in pulsatile shear associated with decreased cardiac output; episodic increases in shear stress associated with exercise training or regular sauna sessions help to correct this problem [73-75]. For all of these reasons, measures which support efficient NOS activity can be beneficial in VH/HF.

The biological gas hydrogen sulfide $\left(\mathrm{H}_{2} \mathrm{~S}\right)$ likewise plays a protective role in this syndrome $[76,77]$. Studies with rodent and cell culture models of $\mathrm{VH} / \mathrm{HF}$ reveal that $\mathrm{H}_{2} \mathrm{~S}$ can act to oppose cardiac hypertrophy, fibrosis, and functional impairment, while promoting 
cardiac angiogenesis [76-80]. The likelihood that these effects are of physiological significance is supported by reports that plasma $\mathrm{H}_{2} \mathrm{~S}$ levels are reduced relative to controls in HF patients and in mice in whom HF has been induced by transverse aortic constriction (TAC); myocardial $\mathrm{H}_{2} \mathrm{~S}$ is also low in mice subjected to TAC [76,81]. Moreover, mice genetically lacking the $\mathrm{H}_{2} \mathrm{~S}$-synthesizing enzyme cystathionine-gamma lyase show an exaggerated response to $\mathrm{HF}$ induction via TAC, whereas the opposite is true of transgenic mice with cardiospecific overexpression of this enzyme [81]. Studies attempting to define the direct targets of $\mathrm{H}_{2} \mathrm{~S}$ in mediating this protection have reported that $\mathrm{H}_{2} \mathrm{~S}$ administration increases activation of eNOS via Akt, increases cardiac expression of antioxidant enzymes via Nrf2 induction, and boosts cardiac expression of vascular endothelial growth factor $[77,81]$. Nrf2-nuclear factor erythroid 2-related factor 2-is a transcription factor that, by binding to antioxidant response elements in the promoters of a number of genes, promotes their transcription; these genes code for an array of enzymes that aid control of oxidative stress and that metabolically transform carcinogens and other toxins to hydrophilic derivatives that can be excreted. One of the enzymes induced is rate-limiting for the synthesis of the ubiquitous cellular antioxidant glutathione. This phenomenon is known as "phase 2 induction" [82].

Increased eNOS activation via Akt-mediated phosphorylation (eNOS expression is not altered) may be of importance to $\mathrm{H}_{2} \mathrm{~S}^{\prime}$ s protective activity in $\mathrm{VH} / \mathrm{HF}$, as eNOS knockout mice subjected to TAC are not benefited by $\mathrm{H}_{2} \mathrm{~S}$ therapy [81]. Akt activation may also mediate the up-regulation of Nrf2 activity induced by $\mathrm{H}_{2} \mathrm{~S}$; Akt inhibits GSK-3 $\beta$ activity, which phosphorylates and antagonizes nuclear translocation of Nrf2 [83]. Additionally, Akt activation would be expected to oppose cardiomyocyte apoptosis [84].

Current pharmaceutical measures for VH/HF include beta-blockers, angiotensin II antagonists, and antagonists of the mineralocorticoid receptor. The former two inhibit activities that, as noted, are key triggers for this syndrome. Cardiac mineralocorticoid receptors (MR), which are constitutively active owing to cortisol binding, contribute to hypertrophy and fibrosis in ways that are still somewhat obscure; non-genomic activation of Nox2-dependent NADPH oxidase activity may play a key role in this regard [85-87]. Pharmaceutical control of hypertension and volume overload, as well as surgical correction of valvular dysfunction, are often employed as ancillary measures. Despite the wellestablished utility of these measures, $\mathrm{VH}$ usually worsens in most patients over time and progresses to HF, itself progressive.

In the discussion which follows, we examine nutraceutical, dietary and lifestyle strategies which may have the potential to complement standard therapy in the prevention and control of the VH/HF syndrome. These measures are intended to: attenuate oxidative stress; suppress ER stress; support efficient production of $\mathrm{NO}$ and $\mathrm{H}_{2} \mathrm{~S}$; and mimic the bioactivity of NO. Other measures which appear likely to be beneficial include: optimizing magnesium (Mg) status; supplementing with taurine, carnitine, copper, and orotate; a whole-food plant-based diet, low in saturated fats, moderate in salt, and rich in potassium; regular exercise training; and sauna.

\section{Attenuating Oxidative Stress}

Hydrogen peroxide, by interacting with relatively acidic cysteines as well as methionines in key proteins, perturbs the function of many proteins in a way that promotes the VH/HF syndrome [88,89]. In particular, oxidation of RyR2 sensitizes it to calcium-mediated opening and promotes diastolic calcium leak [90-92]; oxidation of SERCA2 compromises its pumping activity [93-95]; oxidation of TRPC3/TRPC6 enhances calcium influx through these channels and sensitizes them to activation by diacylglycerol [96,97]; and oxidation of methionine groups in CaMKII locks it in an activated conformation even after intracellular free calcium has declined [24-26]. Oxidation and subsequent S-glutathionylation of NOS induces its uncoupling $[98,99]$. Hydrogen peroxide stemming from Nox4 plays a mediating role in the TGF $\beta$ signaling within cardiac fibroblasts which drives cardiac fibrosis [45,46]. Superoxide and its downstream products peroxynitrite and hydroxyl radical likely also 
contribute to the adverse impact of oxidative stress in VH/HF; in particular, peroxynitrite promotes uncoupling of NOS (thereby suppressing NO production while boosting that of superoxide) by oxidizing tetrahydrobiopterin $[100,101]$. Moreover, peroxynitrite further compromises NO signaling by inducing an inhibitory oxidation of soluble guanylate cyclase [102]. Oxidant stress also promotes NOS uncoupling by impairing the activity of dimethylarginine dimethylaminohydrolase (DDAH), which catabolizes the endogenous NOS inhibitor/uncoupler asymmetric dimethylarginine (ADMA); DDAH is inhibited by covalent interaction with 4-hydroxynonenal, a breakdown product of peroxidized membrane lipids [103-105]. Additionally, superoxide can react spontaneously with NO, destroying its bioactivity and generating toxic peroxynitrite in the process [106].

The centrality of hydrogen peroxide excess in the VH/HF syndrome is highlighted by studies with mice bioengineered to overexpress either mitochondrial or peroxisomal catalase - the former targeting mitochondria, the latter the cytoplasm $[94,95,107]$. These mice prove to be substantially though not wholly protected from VH/HF induced by transaortic banding or isoproterenol infusion; they are also resistant to age-related cardiac dysfunction. These findings strongly emphasize the desirability of controlling oxidative stress in VH/HF.

The main sources of superoxide/hydrogen peroxide in this syndrome appear to be mitochondria, NADPH oxidase complexes, and uncoupled NOS; activated xanthine oxidase may also play a subsidiary role in this regard, but allopurinol appears to provide little benefit in HF [108-110]. Whereas chronic activation of CaMKII is known to promote mitochondrial superoxide production at complex I, locally elevated cytoplasmic free calcium, when taken up by mitochondria, can likewise increase superoxide production at complex I by increasing mitochondrial inner membrane potential [32,111]. Cardiomyocytes express Nox2 and Nox4, whereas Nox 2 is the primary form of NADPH oxidase in vascular endothelium [112]. Rodent studies employing the broad-spectrum NADPH oxidase inhibitor apocynin, or mice genetically engineered to lack Nox 2 or Nox4, reveal that NADPH oxidase is a key contributor to the oxidative stress associated with $\mathrm{VH} / \mathrm{HF}$, and that suppression of NADPH oxidase activity substantially ameliorates this syndrome; likewise, activation of Nox2 in coronary endothelium leads to coronary endothelial dysfunction in VH/HF models $[87,113-120]$. Increased activity of G $\alpha$ q/PLC- $\beta$, by generating diacylglycerol that can activate PKC activity, likely plays a role in promoting Nox2-dependent superoxide production in $\mathrm{VH} / \mathrm{HF}$; in addition, activated mineralocorticoid receptors are known to stimulate Nox2-dependent superoxide production in the heart via a non-genomic mechanism [85-87]. Nox4 is constitutively active, so increased activity of Nox4 in VH/HF likely reflects induction of this protein. Another key source of oxidative stress is uncoupled NOS, which in particular plays a role in diastolic dysfunction $[57,59,60]$. Measures for achieving recoupling of NOS-and hence controlling another source of cardiac oxidative stress-will be considered below.

Coenzyme $\mathrm{Q}_{10}(\mathrm{CoQ})$, which shuttles electrons from complex I and complex II to complex III in the electron transport chain of the mitochondrial inner membrane, was one of the first nutraceuticals to be employed with some success in the management of HF [121-124]; a recent meta-analysis of controlled clinical trials with this agent in HF concludes that CoQ therapy can reduce mortality and improve exercise capacity, though left ventricular ejection fraction (LVEF) did not improve [125]. Since complex I appears to be the chief source of mitochondrial superoxide in $\mathrm{VH} / \mathrm{HF}$, it is reasonable to suspect that CoQ's therapeutic role in this regard reflects its ability to accept electrons from complex I, thereby relieving the over-accumulation of complex I electrons that promotes superoxide production; this might also be expected to aid electron flow down the chain and thereby improve efficiency of ATP generation. CoQ can also act directly as a scavenging antioxidant. CoQ is most efficiently absorbed in its reduced form ubiquinol [126-128].

The intracellular free bilirubin generated by heme oxygenase activity functions as a potent direct inhibitor of certain NADPH oxidase complexes, including those dependent on Nox2 and Nox4 [129-134]. Hence, oxidant-mediated heme oxygenase induction 
provides feedback control of oxidative stress [132]. Recent evidence that serum bilirubin correlates inversely with risk for LVH in hypertensives, independent of blood pressure, may reflect the ability of free bilirubin to blunt the contribution of Nox-mediated oxidative stress to the progression of VH $[135,136]$. Moreover, induction of heme oxygenase-1 activity opposes induction of $\mathrm{VH}$ in rats that are hypertensive or treated with angiotensin II $[137,138]$. Although bilirubin is too insoluble to be administered orally as an antioxidant nutraceutical, chemically related bilins in algae appear to have potential in this regard. The light-harvesting chromophore phycocyanobilin (PhyCB), a major component of certain algae and cyanobacteria such as spirulina, is a close chemical relative (and derivative of) bilirubin's direct precursor biliverdin; within cells, it is rapidly reduced to phycocyanorubin, very similar in structure to bilirubin $[139,140]$. Indeed, orally or parenterally administered PhyCB shares free bilirubin's ability to inhibit NADPH oxidase complexes-which likely rationalizes the profound and versatile protective effects of orally administered spirulina (or of phycocyanin, the protein which contains PhyCB as a covalently linked chromophore) in rodent models of health disorders driven by oxidative stress [140-145]. While the utility of oral PhyCB (or of oral spirulina or phycocyanin) has not yet been tested in rodent models of $\mathrm{VH} / \mathrm{HF}$, oral spirulina has been shown to be protective in doxorubicin-induced heart failure in mice [146]. In vitro, phycocyanin protects cardiomyocytes from this drug [147].

Reduced glutathione works with glutaredoxin to reverse the oxidant effects of hydrogen peroxide on cysteine groups; hence, measures which boost cardiac levels of free glutathione may be helpful in VH/HF [148-150]. This can be achieved with supplemental intakes of $\mathrm{N}$-acetylcysteine (NAC), a delivery form for cysteine, the rate-limiting substrate for glutathione synthesis [151,152]. The efficiency of tissue glutathione synthesis declines in the elderly, owing both to reduced efficiency of the Nrf2-dependent induction of gammaglutamylcysteine sythetase (the rate-limiting enzyme for glutathione synthesis), and a decline in tissue levels of cysteine [153-155]. NAC supplementation in the elderly has been shown to restore youthful tissue levels of glutathione [156]. Not surprisingly, supplemental NAC has been shown to be protective in rodent models of VH/HF [157-159]. Moreover, NAC supplementation also has the potential to enhance cardiac production of $\mathrm{H}_{2} \mathrm{~S}$, as cysteine is the primary substrate for its synthesis [160]. Potentially, phase 2-inducer nutraceuticals such as lipoic acid or ferulic acid could be used to complement NAC's efficacy for boosting glutathione synthesis, as these agents promote Nrf2-mediated induction of gamma-glutamylcysteine synthetase $[153,161]$. They also boost induction of a range of other antioxidant enzymes which potentially could be protective in $\mathrm{VH} / \mathrm{HF}$-including heme oxygenase-1, which generates free bilirubin [162-166].

Oxidant-mediated oxidation of methionine groups in CaMKII plays a key role in promoting chronic activation of this enzyme. The enzyme methionine sulfoxide reductaseA (MSR-A) functions to restore these methionines to their proper conformation [24]. Zinc supplementation of elderly human subjects has been shown to boost expression of MSR-A in peripheral blood leukocytes; whether this effect also obtains in cardiomyocytes has not yet been studied [167]. Zinc supplementation also promotes induction of the cysteine-rich antioxidant protein metallothionein, which has been shown to be protective in rodent models of diabetic cardiomyopathy [168-174]. Metallothionine induction can antagonize the pro-oxidant activity of cadmium $(\mathrm{Cd})$, a heavy metal contaminant that has been linked to increased risk for heart failure and other cardiovascular pathologies [175-177]. Indeed, a number of studies have linked increased cadmium body burden (as assessed by urinary $\mathrm{Cd}$ corrected for creatinine) to increased risk for and mortality from heart failure [178-183]. The utility of supplemental zinc in rodent models of VH/HF merits study. Curiously, in the AREDS1 study examining the potential of nutraceuticals for control of macular degeneration, supplementation with zinc ( $80 \mathrm{mg}$ daily, complemented by $2 \mathrm{mg}$ copper) was associated with a highly significant $27 \%$ reduction in total mortality over about 6 years of follow-up [184]. If this effect is confirmable, a favorable impact of supplemental zinc on the heart may be in part responsible for this protection. Indeed, a recent cross-sectional 
study has found that serum zinc levels are lower in patients with LVH than in healthy controls, and that serum zinc correlates inversely with left ventricular mass [185].

Selenium is an essential cofactor for various antioxidant enzymes that likely would be protective in $\mathrm{VH} / \mathrm{HF}$, including glutathione peroxidase, thioredoxin reductase, and methionine sulfoxide reductase-B1 [186,187]. Although dietary selenium intakes throughout most of the US are sufficient to optimize selenium's availability for enzyme production, this is not true in certain regions of Europe and Asia where soil selenium is quite low. Hence, modest supplemental intakes of selenium might be beneficial for heart health in these regions $[188,189]$. Not surprisingly, severe pediatric selenium deficiency, as was seen in certain regions of China, was associated with a severe cardiomyopathy (Keshan disease) [190]. In a double-blind supplementation trial, in which elderly Swedes were supplemented with selenium + coenzyme $\mathrm{Q}$ or matching placebo for four years, the cardiovascular mortality rate was about half as high (HR: $0.51 ; 95 \% \mathrm{CI} 0.36-0.74 ; p=0.0003$ ) in the active treatment group, and plasma levels of N-terminal brain natriuretic peptide (BNP) were significantly lower than in controls, suggestive of a favorable effect on $\mathrm{VH}$; benefit was seen primarily in those with low baseline selenium, common in elderly Swedes [191-193].

Excess oxidant production in cardiomyocyte mitochondria, a feature of $\mathrm{VH} / \mathrm{HF}$, might be expected to lead to oxidant damage to the mitochondrial respiratory chain which in turn boosts superoxide production or compromises efficient ATP synthesis. Therefore, a lipid soluble membrane antioxidant such as astaxanthin - shown to be protective in rodent models of ischemia-reperfusion damage [194-196] — might be expected to aid preservation of mitochondrial function and minimize mitochondrial oxidant production in $\mathrm{VH} / \mathrm{HF}$. Indeed, administration of astaxanthin has been shown to lessen heart oxidant stress in aged rats given repeated injections of isoproterenol [197].

The neurohormone melatonin amplifies phase 2 induction by increasing expression of Nrf2 at the transcriptional level, likely by increasing expression of the clock protein Bmal1, a clock protein transcription factor which binds to the promoter of the Nrf2 gene [198,199]. However, melatonin, likely via Bmal1, also promotes transcription of the gene coding for the deacetylase Sirt1 [200,201]. Sirt1 exerts anti-fibrotic activity in the heart and other organs by opposing TGF $\beta$ signaling in several complementary ways. Sirt1 activity promotes proteasomal degradation of p300, a histone acetyltransferase which acts as a cofactor for TGF $\beta$-induced Smad2/Smad3-mediated transcription [202-204]. Sirt1 also deacetylates Smads 2, 3 and 4, and some evidence suggests that this may also interfere with TGF $\beta$ mediated signaling $[205,206]$. Melatonin administration has been shown to inhibit cardiac fibrosis in several rodent models of this condition [207-211].

\section{Inhibiting ER Stress}

As noted, the loss of sarcoplasmic reticulum calcium associated with $\mathrm{VH} / \mathrm{HF}$ gives rise to ER stress [212]. This can lead to cardiomyocyte apoptosis via induction of CHOP and activation of JNK/p38 MAP kinase; ER stress also promotes cardiomyocyte inflammation via activation of NF-kappaB [213]. ER stress within fibroblasts promotes cardiac fibrosis [51,53]. The administration of certain chemical chaperones, such as tauroursodeoxycholic acid (TUDCA) and 4-phenylbutyrate, aids control of ER stress by promoting proper protein folding, and indeed has been shown to be highly protective in rodent models of VH/HF [53,54,214-218]. TUDCA is of particular interest in this regard because it is a naturally occurring bile salt that, while used clinically to treat certain cholestatic liver disorders, is also available as a nutraceutical. The oral doses of TUDCA found to be protective in rodent models of VH/HF extrapolate to about 2-3 g daily (preferably in divided doses) in humans. Such a regimen would likely be feasible, though rather expensive- $4-6$ US dollars daily at current retail prices.

Berberine, a phytochemical found in certain Chinese herbs, has long been used as a treatment for diabetes in China [219-221]. Its efficacy in this regard is thought to reflect its ability to activate AMPK in a manner comparable to the diabetes drug metformin $[222,223]$. However, berberine has also been used in China as a treatment for heart failure. Controlled 
trials have demonstrated that berberine administration at 1-2 $\mathrm{g}$ daily can increase ejection fraction, increase exercise capacity, lessen ventricular premature contractions, and decrease mortality in heart failure patients; results in rodent models of $\mathrm{VH} / \mathrm{HF}$ reinforce this impression [224-227]. Curiously, there is also some evidence that metformin is beneficial in diabetics with heart failure; these findings thus point to the possibility that activation of AMPK is protective in this syndrome $[228,229]$. If so, improvement of ER stress could be a key mediator of this benefit.

A number of rodent and cell culture studies demonstrate that activation of AMPK opposes ER stress [230-234]. AMPK functions as a detector of energy shortage; it promotes adaptation to such a shortage by boosting the activity of pathways that generate ATP, while slowing those that consume it [235]. One of the ways it accomplishes this is to confer an activating phosphorylation on eEF2 kinase, which in turn phosphorylates eEF2 [236,237]. The latter is an elongation factor that promotes swift translation of mRNAs; its activity in this regard is blunted by the phosphorylation mediated by eEF2 kinase. Hence, AMPK conserves ATP by slowing the rate of protein synthesis globally. Since ER stress reflects an inability of ER protein folding mechanisms to keep up with the rate of protein synthesis, the slowing of protein synthesis induced by AMPK activity could be expected to lessen ER stress, as in fact is observed experimentally. Furthermore, this mechanism would likely be complementary to that of TUDCA, which aids the efficiency of proper protein folding. Hence, berberine + TUDCA (abetted by measures for control of oxidative stress, as described above), might be expected to have general utility for combatting ER stress. In addition, it should be noted that AMPK can also confer an activating phosphorylation on eNOS [238,239] — and NO/cGMP/PKG oppose ER stress by inducing phosphorylation of phospholamban and hence activating SERCA2a.

\section{Supporting NO/cGMP Production}

The antioxidant measures cited above would likely help to prevent NOS uncoupling by decreasing peroxynitrite-mediated oxidation of tetrahydrobiopterin to dihydrobiopterin, and oxidant-mediated inhibition of DDAH. NOS is only fully coupled when it binds to both arginine and tetrahydrobiopterin; ADMA and dihydrobiopterin compete with these compounds for binding to NOS, and hence promote uncoupling [240]. Supraphysiological doses of folic acid have been shown to induce increased expression of dihydrofolate reductase in the vascular endothelium [241-243]; this enzyme is capable of reducing dihydrobiopterin back to its tetrahydro- cofactor form. Additionally, within cells, folate is converted to reduced forms which can efficiently scavenge peroxynitrite-derived radicals, and thereby protect tetrahydrobiopterin [244-246]. Hence, high-dose supplemental folate has been found to promote proper coupling of eNOS in vascular endothelium and improve dysfunctional endothelium-dependent vasodilation [247-249]. Whether highdose folate could also induce dihydrofolate reductase in cardiomyocytes has not been studied; cardiomyocyte expression of this enzyme tends to be low [250]. Indeed, that's why direct administration of tetrahydrobiopterin or its precursor sepiapterin has proved of minimal clinical value for recoupling NOS in cardiomyocytes-tetrahydrobiopterin is rapidly oxidized to its dihydro- form, which tends to accumulate and inhibit access of tetrahydrobiopterin to the enzyme. In any case, high-dose folate likely would promote coupling of eNOS in the coronary vascular tree; indeed, acute oral administration of $30 \mathrm{mg}$ folate has been shown to improve flow-mediated vasodilation in the coronary tree of angina patients [251]. In mice subjected to transverse aortic constriction, pre-feeding with a diet supplemented with high doses of both folate and cobalamin was associated with a reduction in $\mathrm{LVH}$ and a preservation of $\mathrm{EF}$; however, this benefit did not reflect control of oxidative stress, but rather a preservation of mitochondrial biogenesis likely attributable to increased methylation reactions [252]. Folate has also been shown to be highly protective for doxorubicin-induced cardiomyopathy in mice, as well as in a rat model of myocardial ischemia-reperfusion injury $[253,254]$. 
HF is associated with increased plasma ADMA levels-in part owing to decreased renal perfusion - and elevated ADMA is associated with poor prognosis [255-260]. Additionally, independent of renal function, ADMA levels correlate with left ventricular mass; this correlation has been observed in the normal aging population [261-264]. These findings suggest that, whereas diminished cardiac output can cause elevations of ADMA, elevations of ADMA may also increase risk for VH/HF. When ADMA levels are elevated-as they often are in patients with $\mathrm{VH} / \mathrm{HF}$ - boosting tissue levels of NOS' substrate arginine can promote NOS coupling in the heart by increasing the arginine/ADMA ratio [240,265]. Counterintuitively, supplementation with citrulline (remarkably, a major component of watermelon juice [266]) is more efficient for increasing tissue levels of arginine than is supplementation with comparable doses of arginine; this reflects the fact that inducible arginase activities in gut bacteria and the liver tend to degrade orally administered arginine to ornithine before it can reach the systemic circulation [267-269]. Citrulline, in contrast, is not degraded by arginase (indeed, it competitively inhibits this enzyme), and, in cells expressing NOS activity, it is rapidly converted to arginine. Furthermore, citrulline protects this derived arginine within these tissues by inhibiting arginase. Moreover, citrulline, as contrasted to arginine, has a pleasant mild flavor and is readily administered in multigram doses in fluids [240]. Hence, supplemental citrulline may have potential for use in management of VH/HF. Indeed, in a randomized controlled study (lacking a placebo), patients with HF receiving $3 \mathrm{~g}$ citrulline daily for 4 months achieved improvements in LVEF, RVEF, and endothelial function that were significant both with respect to baseline and controls [270]. In 35\% of the treated patients, functional class improved.

Premenopausal women, as compared to men, are less prone to develop VH/HF, and have a better prognosis when they do; this protection is lost after menopause [271-273]. Conversely, postmenopausal estrogen replacement therapy has been shown to oppose increases in LV mass [274-276]. Likewise, estrogen administration protects ovariectomized female rodents in models of $\mathrm{VH}$ induction, and, importantly, male rats are also protected [277-280]. Cardiomyocytes express both $\alpha$ and $\beta$ forms of the estrogen receptor, and this expression does not differ by sex $[281,282]$. Studies with estrogen receptor knockout mice reveal that estrogen receptor- $\beta(E R \beta)$, rather than estrogen receptor- $\alpha(E R \alpha)$, mediates protection from $\mathrm{VH}$ [283-285]. Consistent with this finding, pharmaceutical agonists specific for ER $\beta$ protect rodents from $\mathrm{VH}$, and cardiomyocyte-specific overexpression of ER $\beta$ is likewise protective [286-288]. Increased cardiac expression of eNOS appears to be at least partially responsible for this ER $\beta$-mediated protection $[289,290]$.

Fortuitously, the soy isoflavone genistein, when administered in doses that could feasibly be achieved with a high intake of soyfoods, produces plasma levels of free unbound genistein that are sufficient to activate $E R \beta$, but too low to meaningfully activate ER $\alpha$ [291-293]. The daidzein metabolite S-equol_produced by intestinal bacteria to varying extents after ingestion of soy isoflavones-likewise can selectively activate ER $\beta$ in concentrations produced by soyfood ingestion [294]. This is presumably why soy isoflavones can provide a range of health benefits without provoking feminizing side effects in men [293]. This also rationalizes a number of recent reports that oral genistein is beneficial in rodent models of VH/HF [295-300]. The protection afforded by genistein in these studies is associated with increased myocardial activity of eNOS, and is abolished by the NOS inhibitor L-NAME, but not by a specific inhibitor of inducible NOS $[295,297,300]$. This increased activity of eNOS appears to reflect both increased expression of the enzyme and increased Akt-mediated phosphorylation; studies differ as to the relative importance of these effects. Asian epidemiology evaluating the impact of soyfood consumption on risk for this syndrome unfortunately is not yet available.

Raw cocoa powder is rich in the flavanols epicatechin, catechin, and polymerized complexes thereof, known as oligomeric procyanidins (OPCs). The favorable impact of cocoa on cardiovascular health has been traced to the ability of cocoa flavanols, notably epicatechin and some OPCs, to up-regulate the eNOS activity of vascular endothelium, boosting endothelium-dependent vasodilation [301,302]. Although this mechanism may 
not increase eNOS activity in cardiomyocytes and fibroblasts, it can increase the heart's exposure to NO produced by the coronary microvasculature. Moreover, by improving flow-mediated vasodilation systemically, it can decrease the ventricular afterload that the heart must cope with. In vitro studies show that both epicatechin and high-molecularweight OPCs can act on endothelial cells to promote Ser1177 phosphorylation of eNOS by activating the PI3K/Akt pathway; this boosts eNOS activity and up-regulates its further activation by stimuli such as shear stress which increase cytosolic free calcium in endothelial cells $[303,304]$. A recent crossover clinical study has found that ingestion of about a gram of cocoa flavanols daily by HF patients can decrease both diastolic blood pressure and $\mathrm{N}$-terminal-pro-BNP levels [305]. Moreover, other food and herbal extracts rich in OPCs have potential for improving defective endothelial function in HF patients [306]. OPC-rich extracts of hawthorn (Crataegus oxyacantha) have long been employed in the clinical management of HF, and their high-molecular weight OPCs have likewise been found to activate eNOS in vitro via PI3K/Akt [307,308]. Although results of clinical studies with hawthorn extracts have yielded inconsistent results, a meta-analysis of randomized controlled trials has concluded that treatment with standardized OPC-rich hawthorn extracts can indeed confer symptomatic benefit in $\mathrm{HF}$, increasing exercise capacity and lessening shortness of breath and fatigue [309].

Dietary nitrate is reduced to nitrite by oral bacteria, and this nitrite can be absorbed. In tissues that are relatively hypoxic and/or acidic, certain deoxygenated heme proteins such as hemoglobin, myoglobin, and xanthine oxidoreductase are capable of reducing nitrite to NO $[310,311]$. Hence, dietary nitrate may represent a NOS-independent strategy for increasing NO production in ischemic tissues, thereby improving their perfusion. Clinical studies with supplemental nitrate, often administered as beet juice, document a modest reduction in systemic blood pressure - of meaningful magnitude in hypertensives-that might be worthwhile for some patients with VH/HF [312-316]. In addition, nitrate may have an effect on exercise efficiency that could be of particular value to HF patients, whose exercise capacity is notably impaired. For reasons that remain mysterious, nitrate administration has been found to modestly decrease the oxygen uptake required to achieve a given power output in skeletal muscle; this might be expected to improve performance in certain types of exercise when muscle perfusion is diminished-as when cardiac output is low [317,318]. Moreover, in rats with HF owing to a previous induced infarction, nitrate administration for 5 days prior to an exercise trial was found to boost skeletal muscle blood flow by about $20 \%$ [319]. In HF patients, beet juice administration has been reported to modestly increase submaximal endurance and peak power production [320,321]. Three clinical trials, including one specifically targeting patients with HF with preserved ejection fraction, have shown exercise benefits with beet juice ingestion; a study enrolling only patients with reduced ejection fraction did not observe benefit [320-323]. Whether dietary nitrate could boost NO production in relatively hypoxic myocardial regions, thereby enhancing cardiac cGMP generation and opposing progression of $\mathrm{VH} / \mathrm{HF}$, has not yet been assessed, either clinically or in rodents. Hence, aside from the impact of its modest anti-hypertensive activity, it is not yet clear whether dietary nitrate can provide more than symptomatic benefit in HF.

Drugs that directly activate soluble guanylate cyclase (sGC) - in its native or oxidatively inhibited form-have shown marked utility in rodent models of $\mathrm{VH} / \mathrm{HF}$, and are now being studied clinically in HFpEF [324-329]. Largely overlooked is the fact that, in concentrations two orders of magnitude higher than the physiological range, the B vitamin biotin can boost sGC's production of cGMP by 2-3-fold [330-332]. (Whether it shares the ability of sGC stimulator drugs to amplify this enzyme's sensitivity to NO has not been studied.) In spontaneously hypertensive stroke-prone rats, high oral doses of biotin have been shown to exert an antihypertensive effect that is abrogated by an sGC inhibitor; this supplementation also led to a marked reduction in stroke-mediated mortality [333]. More recently, high-dose biotin has shown well-tolerated clinical utility in progressive multiple sclerosis, an effect which might be mediated by CNS cGMP [334,335]. Benefits 
of high-dose biotin in diabetic rodents and humans are also likely traceable to increased cGMP production [336]. In light of the fact that high-dose biotin appears to be safe, welltolerated (reflecting the modest extent to which it can activate sGC, as compared to NO), and reasonably affordable in doses likely to achieve mild systemic activation of sGC, its utility in VH/HF merits evaluation. However, it should be noted that use of high-dose biotin can interfere with certain clinical assays that use streptavidin-biotin technology, mandating its temporary discontinuation in some circumstances [337].

Oxidation of the ferrous heme of sGC - which is readily induced by peroxynitriterenders it unstable, such that the heme can dissociate from the enzyme, negating the ability of NO, sGC stimulator drugs, and likely biotin to activate it [102]. Hydrogen sulfide, more effectively than glutathione, functions to maintain the heme iron of sGC in its reduced ferrous valence, thereby stabilizing the enzyme [338]. Hence, measures which promote $\mathrm{H}_{2} \mathrm{~S}$ synthesis in the heart may complement the utility of biotin or $\mathrm{NO}$ for boosting cGMP production.

Phosphodiesterases targeting cGMP have evident potential for managing VH/HF. PDE5 inhibitors, employed clinically to treat erectile dysfunction, are useful in rodent models of VH/HF [61,339]. Human trials demonstrate that the PDE5 inhibitor sildenafil provides hemodynamic, symptomatic, and mortality benefits in HF with reduced ejection fraction, but not in HFpEJ [340-342]. The basis of this discrepancy is not clear-perhaps it reflects a very severe loss of $\mathrm{NO}$ bioactivity in the latter syndrome. Recently, $\mathrm{H}_{2} \mathrm{~S}$ has been shown to have PDE5-inhibitory activity; hence $\mathrm{H}_{2} \mathrm{~S}$ acts within the heart both to promote the synthesis of $\mathrm{NO}$ and support its bioactivity [343].

\section{Optimizing Omega-3 Status}

Long-chain omega-3 fatty acids, notably the eicosapentaenoic acid (EPA) and docosahexaenoic acid (DHA) found in fish oil, work in a variety of ways to protect the heart and cardiovascular system [344]. The impact of omega-3 status on risk for sudden-death arrhythmias has been traced to the ability of membrane omega-3s to interact with cardiac ion channels-notably fast voltage-dependent sodium channels and L-type calcium channelsin a way that reduces their open probability, rendering cardiac membranes more electrically stable $[345,346]$. Diets rich in EPA have been shown to decrease cardiac fibrosis in rodent models of pressure overload, reflecting the ability of EPA to activate GPR120 receptors on cardiac fibroblasts; this effect is dependent on an increase in fibroblast cGMP/PKG activity [347-349]. Additionally, the ratio of EPA to arachidonic acid (AA) in membranes or in plasma free fatty acids can determine the extent to which AA is converted to proinflammatory eicosanoid signaling factors $[344,350]$. EPA competes with AA for access to cyclooxygenase and other enzymes which produce such mediators; furthermore, these enzymes tend to convert EPA to mediators that are less pro-inflammatory/pro-aggregatory than those derived from AA, or that antagonize the interaction of AA-derived eicosanoids with their receptors. Importantly, the prostacyclin derived from EPA, PGI3, is as effective for promoting human platelet stabilization as is the PGI2 derived from AA-whereas the thromboxane derived from EPA is inactive [351-353]. A recent prospective study in patients with heart failure found that those in whom the EPA/AA ratio of plasma lipids was relatively high experienced notably lower subsequent mortality than those in whom this ratio was lower; curiously, this effect was more dramatic in patients taking statins [354]. Other studies have found that this ratio predicts the stability of coronary plaque-a high ratio correlating with more stable plaque, likely pointing to a role for AA-derived eicosanoids in plaque destabilization; furthermore, a high EPA/AA ratio would tend to stabilize platelets by decreasing thromboxane activity [355-358]. Hence, the fact that statin-treated heart failure patients achieve greater protection from a high EPA/AA ratio may reflect the fact that statin therapy is acting as a marker for coronary atherosclerosis and hence risk for myocardial infarct.

Since patients with VH/HF are more prone to arrhythmias, and often have coronary plaque, and since sufficient levels of EPA appear to provide protection from cardiac fibrosis, 
it would seem reasonable for VH/HF patients to optimize their omega-3 status, particularly with respect to EPA. The utility of a given daily intake of EPA/DHA will be influenced by the amount and type of other lipids ingested [359]. If one's diet is low in total fat, and if omega-6 fatty acids (capable of being converted to AA) constitute a modest proportion of that fat, a given intake of EPA will yield a higher fraction of EPA in membranes and plasma free fatty acids, as well as a higher ratio of EPA/AA. It is notable that plant-based diets are devoid of AA. Hence, a low-fat plant-based diet, in which oleic acid and $\alpha$-linolenic acid predominate over linoleic acid, may be the ideal setting for gaining the most protective benefit from a given supplemental intake of EPA/DHA. The equivocal results of many clinical trials with supplemental omega-3s may reflect a modest dose interacting with high-fat, high omega-6 diets.

\section{Ancillary Supplements-Mg, Orotate, Carnitine, Taurine, Glycine, and Copper}

Epidemiologically, low serum or dietary levels of magnesium $(\mathrm{Mg})$ have been associated prospectively with increased risk for VH/HF [360-366]. Moreover, certain drugs typically used in management of heart failure can compromise $\mathrm{Mg}$ status [367]. Although long-term supplementation trials have not yet evaluated the impact of magnesium in clinical $\mathrm{VH} / \mathrm{HF}$, the possibility that maintaining relatively high cardiac levels of $\mathrm{Mg}$ may provide some protection in this syndrome merits evaluation. At physiological cellular concentrations, $\mathrm{Mg}$ competes with calcium for binding to the N-terminal arm of calmodulin [368-370]. When partially Mg-bound, this protein is less capable of activating certain enzymes than is calmodulin in which Ca occupies all the binding sites. Hence, when cytoplasmic levels of free $\mathrm{Mg}$ are relatively low, the ability of elevated $\mathrm{Ca}$ to activate calmodulin-dependent enzymes-such as calcineurin and CaMKII may be up-regulated. Additionally, the ability of $\mathrm{Ca}$ to open RyR2 receptors is opposed by $\mathrm{Mg}$ - so cytoplasmic levels of free $\mathrm{Mg}$ may regulate this interaction as well [371]. Assuring good Mg status may be smart policy in patients coping with VH/HF. Evidence that calcium supplementation may increase cardiovascular risk in women may reflect the ability of such supplementation to impair Mg absorption and retention in the context of low-Mg diets [372,373]. This would argue for complementing calcium supplementation with concurrent $\mathrm{Mg}$ supplementation.

$\mathrm{Mg}$ also helps to prevent medial vascular calcification by counteracting the tendency of high-normal phosphate exposure to induce a phenotypic transition of vascular smooth muscle to osteoblast-like cells [374-376]. The mechanism of this protective effect is unclear, but intracellular Mg uptake is required. In kidney failure patients on dialysis-in whom serum phosphate levels tend to be high-as well as in the general population, higher serum Mg levels predict decreased risk for vascular calcification [377-381]. Since arterial and valvular calcification can increase the afterload on the heart, good Mg status and other measures which help to prevent such calcification have some value for primary prevention of VH/HF. In this regard, it should be noted that adequate intakes of the bacterially synthesized menaquinone form of vitamin $\mathrm{K}$ may also have utility, by promoting optimal $\gamma$-glutamyl carboxylation of the matrix Gla protein, an antagonist of calcium crystal deposition [382-384]. Menaquinones achieve better distribution to peripheral tissues than does the plant-derived phylloquinone form of vitamin $\mathrm{K}$, which is largely retained by the liver for manufacture of clotting proteins [385].

The Mg salt Mg orotate has shown utility in rodent models of VH/HF, and favorable effects have been reported with this agent in small, short-term clinical trials in heart failure [386-389]. One longer-term trial is of particular note: $\mathrm{Mg}$ orotate was tested versus placebo in a randomized controlled trial enrolling patients with severe HF; the active group received $6 \mathrm{~g}$ daily for a month, and $3 \mathrm{~g}$ daily for another 11 months. At the end of the trial, mortality had been $52 \%$ in the treated group vs. $76 \%$ in the placebo group $(p<0.05)$, and clinical symptoms had improved in 38\% of the treated group [390]. As Mg per se seems unlikely to account for an effect of this magnitude, orotate was thought to make an important contribution in this regard. Orotate, a pyrimidine metabolite, is converted by the liver to beta-alanine, and returned to the circulation [391,392]. In heart, skeletal muscle, and 
the central nervous system, beta-alanine is a precursor for carnosine and other histidinecontaining dipeptides which function both as antioxidants, membrane protectants, and as buffers for intracellular acidity [392,393]. Indeed, supplemental beta-alanine has been shown to improve performance in high-intensity exercise, likely by buffering the acidity stemming from lactic acid production [394,395]. A recent clinical trial has found that $500 \mathrm{mg}$ carnosine daily improves walking time and quality of life in HF patients; this benefit likely was mediated by beta-alanine, since carnosine is rapidly degraded to its constituents after oral administration [396,397].

Contrary to recent concerns that dietary or supplemental carnitine might increase vascular risk by boosting trimethyl-N-oxide production, [398]. carnitine administration to patients who have experienced a myocardial infarct is associated with a marked reduction in overall mortality, as confirmed by meta-analysis [399-401]. Supplemental carnitine has also been studied as an adjunct to the management of HF in a number of controlled trials, mostly of modest size. A recent meta-analysis of these studies found that supplemental carnitine significantly improved ejection fraction and other cardiac functional parameters, and lowered plasma levels of cardiac natriuretic hormones [402]. A trend toward lower overall mortality in the carnitine-treated patients just failed to achieve traditional statistical significance $(p=0.06)$. The mechanistic basis of carnitine's benefit in these patients remains unclear. In the setting of ischemic coronary disease, it is known that carnitine helps to limit lactic acid production in cardiomyocytes by disinhibiting pyruvate dehydrogenase (owing to increased conversion of acetyl-coA to acetyl-carnitine, and a consequent decline in the acetyl-coA/free coA ratio that regulates pyruvate dehydrogenase kinase activity [403]) and thereby diverting more pyruvate to oxidation rather than to lactate production; this effect might also be pertinent in cardiomyocytes that are relatively hypoxic owing to the capillary rarefication often associated with $\mathrm{VH} / \mathrm{HF}$ [404]. Acid generation in cardiomyocytes tends to provoke calcium overload, since intracellular protons are exchanged for extracellular sodium, and the resulting increase in intracellular sodium acts to drive calcium uptake via the sodium-calcium exchanger [405]. Could acid-buffering be a physiological role of carnosine and other histidine-based small molecules synthesized in the heart [406]?

For reasons that remain unclear, multi-gram daily supplemental intakes of taurine exert a positive inotropic effect on the failing heart that appears to be safe (i.e., not associated with the increased risk for arrhythmias seen with cardiotonic glycosides); improvements in LV ejection fraction and walking distance have been reported in several controlled trials [407-410]. Similar benefits have been reported in rabbit models of heart failure [411,412]. Conversely, cats fed a taurine-deficient diet develop fatal cardiomyopathy (as they lack the capacity to synthesize this agent), and genetic knockout of the cardiac taurine transporter likewise causes heart failure $[413,414]$. Whereas taurine supplementation can provide functional benefit in pre-existing heart failure, whether optimal taurine status might provide protection with respect to progression of $\mathrm{VH}$ has received little study. A reason to suspect that it might has emerged recently. In vascular endothelium, taurine has been shown to promote increased expression of two enzymes that convert can convert cysteine to $\mathrm{H}_{2} \mathrm{~S}$ - cystathionine- $\beta$-synthase, and cystathionine- $\gamma$-lyase [415]. Indeed, this effect appears to be a mediator of the anti-hypertensive and anti-atherosclerotic effects of taurine demonstrated in rodents [416-418]. Combined supplementation with NAC and taurine therefore appears to be a practical strategy for boosting the production of protective $\mathrm{H}_{2} \mathrm{~S}$ in the vasculature [160]. Could taurine also increase expression of $\mathrm{H}_{2} \mathrm{~S}$-synthesizing enzymes in cardiomyocytes? This should be studied. In any case, taurine supplementation appears to be a worthwhile, safe, and inexpensive strategy for managing HF, though its mechanism of action at the molecular level still requires clarification.

Glycine-gated chloride channels are expressed by a range of tissues, including cardiomyocytes [419]. Increases of plasma glycine within the physiological range increase the open probability of these channels, which exert a hyperpolarizing effect on cell types which do not concentrate chloride, as their activation induces an influx of chloride [420,421]. Indeed, glycine has been reported to hyperpolarize cardiomyocytes [419]. Hyperpolariza- 
tion would be expected to down-regulate calcium influx through voltage-activated L-type calcium channels, which mediate much of the calcium influx that drives VH. Perhaps that rationalizes a recent report that a glycine-enriched diet attenuates the development of $\mathrm{VH}$ in mice subjected to pressure overload or angiotensin II administration [422]. In vitro, glycine blunted the ability of angiotensin II to evoke increased release of TGF $\beta$ from cardiomyocytes-pointing to a likely protective effect on cardiac fibrosis [422]. Glycine administration has also been shown to diminish infarct area in rats subjected to myocardial ischemia reperfusion [423]. Moreover, glycine stabilizes platelets in vitro, and bleeding time is increased in rats fed glycine [424]. Of considerable interest is a prospective epidemiological study in which higher serum glycine levels correlated with decreased risk for myocardial infarction in patients with stable angina; those in the fifth quintile of serum glycine, as compared to the first quintile, were about 30\% less likely to develop an MI, after statistical adjustment for recognized risk factors [425]. Supplemental glycine may complement the utility of NAC administration for raising cellular glutathione levels [156]. Glycine has good potential for inclusion in functional foods and beverages, as it is highly soluble, mildly sweet, and inexpensive in multi-gram doses [421].

There is evidence that a decline of myocardial copper levels contributes to the failure of adaptive angiogenesis that leads to capillary rarefication as the overloaded heart transitions from hypertrophy to failure [56]. The basis of this decline requires clarification, although an increase in the production of copper-chelating homocysteine in heart tissue has been suggested as a basis for this [426]. In any case, copper is known to act as a co-factor in the HIF-1-driven transcription of the genes encoding VEGF and other proteins that promote adaptation to hypoxia. Copper does not influence HIF- $1 \alpha$ stability or nuclear translocation, but is somehow necessary for binding of HIF-1 to its response elements in the promoters of its target genes; some evidence suggests that copper-mediated inhibition of the factor inhibiting HIF-1 (FIH-1) may be responsible for this effect [427]. Copper's role in supporting angiogenesis has led to the exploration of copper deprivation as a strategy for slowing cancer growth [427]. Remarkably, correction of the decline in myocardial copper levels in rats subjected to pressure overload with a copper-enriched diet not only prevents a decline in VEGF levels and boosts myocardial angiogenesis, but also exerts an anti-hypertrophic effect [56] - possibly by lowering cardiac levels of VEGFR-2 [428]. Optimization of cardiac copper status may also have a favorable impact on the activities of copper-zinc-dependent superoxide dismutase and mitochondrial cytochrome oxidase in the failing heart [429]. Although clinical studies have not yet evaluated the impact of copper supplementation per se on $\mathrm{VH} / \mathrm{HF}$, a controlled trial in which $\mathrm{HF}$ patients received a multi-vitamin-mineral supplement or matching placebo observed a reduction in LV mass and an increase in LV ejection fraction-both modest, but significant-in those receiving the supplement [430]; this supplement provided 1.2 mg copper per day, and Klevay has suggested that this copper may have been a key mediator of the benefit observed in this supplementation trial [431]. Defective copper uptake by cardiomyocytes is also seen in diabetes, and diabetic cardiomyopathy in rats is remedied by a copper-specific chelating agent (trientine) which reverses this intracellular copper deficiency [432]. It should be noted that high-dose zinc supplementation has the potential to decrease body copper stores by inducing metallothionein in the intestinal mucosa-for which reason it has been used in the treatment of Wilson's disease [433]; hence, if zinc supplementation is employed in the management of $\mathrm{VH} / \mathrm{HF}$, concurrent supplementation with copper may be particularly wise.

Primary hyperparathyroidism tends to be associated with increased ventricular masspossibly reflecting a direct impact of parathyroid hormone (PTH) on cardiomyocytesand treatment of this syndrome with parathyroidectomy tends to decrease ventricular mass $[434,435]$. It is therefore reasonable to suspect that the secondary hyperparathyroidism seen when vitamin D status is low might likewise increase $\mathrm{VH}$ risk. Indeed, epidemiological studies have found that low plasma levels of 25-hydroxyvitamin D (25-OHD) correlate inversely with ventricular mass, predict future onset of $\mathrm{VH}$, and are associated with poor 
prognosis in pre-existing heart failure [436-441]. Nonetheless, supplementation trials with vitamin D in patients with VH or HF have yielded equivocal results, and a recent metaanalysis of controlled studies of vitamin D supplementation in HF patients found that such supplementation did not improve LV ejection fraction, decrease plasma $\mathrm{N}$-terminal pro-B type natriuretic peptide, or increase 5-min walking distance [442]. It therefore seems likely that, when lower 25-OHD is found to correlate inversely with VH/HF risk, lower 25-OHD is simply functioning as a marker for metabolic syndrome/obesity, which themselves promote VH [443-445]. Indeed, Mendelian randomization studies focused on genetic determinants of plasma 25-OHD have concluded that, whereas low vitamin D status may indeed be a mediator of increased cancer and overall mortality, it does not appear to influence cardiovascular risk [446]. Mendelian randomization has not yet been employed to assess the impact of vitamin D status on risk for VH/HF per se, but it seems unlikely that vitamin D would fail to influence overall cardiovascular mortality if it had an important effect on risk for $\mathrm{VH} / \mathrm{HF}$. Hence, whereas vitamin D supplementation may prove to be wise from the standpoint of overall health, whether it will notably influence risk for VH/HF is dubious. Perhaps commonly occurring degrees of vitamin D deficiency do not elevate PTH sufficiently to have an important effect on the heart.

\section{Protective Diet and Lifestyle Measures}

Metabolic syndrome, central obesity, and diabetes substantially increase risk for $\mathrm{VH} / \mathrm{HF}$, independent of their common association with hypertension [447-457]. These disorders are characterized by high tissue exposure to free fatty acids, and there is reason to suspect that increased exposure to long-chain saturated fatty acids is a mediator of this increased risk. Cardiomyocytes and fibroblasts express Toll-like receptor 4 (TLR4); longchain saturated fatty acids can activate TLR4 by forming a ternary complex with it and the plasma protein fetuin-A, and palmitate has been shown to activate TLR4 on cardiomyocytes in vitro [458-462]. This receptor likewise responds to lipopolysaccharides and certain proteins signaling inflammatory damage, mediating the adverse effect of chronic infections (such as periodontitis [463-465]) on VH/HF risk and of sepsis on cardiac function [466-471]. TLR4 activation in cardiomyocytes can lead to oxidative stress, CaMKII activation, ER stress, and apoptosis [461,472-474]. Increased synthesis of diacylglycerol and of ceramide may also mediate adverse effects of saturated fatty acids on cardiomyocytes [475-477]. A recent prospective study of patients with $\mathrm{HF}$ found that saturated fat intake correlated positively with mortality rate, whereas polyunsaturated intake correlated negatively [478]. Another prospective study has linked increased plasma levels of saturated fats (especially myristate) to increased risk for HF [479]. These findings suggest that diets in which longchain saturated fats constitute a small fraction of total fat content might be relatively protective with respect to $\mathrm{VH} / \mathrm{HF}$, especially in those with metabolic syndrome, obesity or type 2 diabetes.

Plant-based diets tend to be relatively low in saturated fat as a percentage of total fat, and the studies of Esselstyn have shown that strict adherence to a whole-food lowfat plant-based diet, coupled with sufficient medication as needed to maintain optimal LDL cholesterol levels, can achieve almost complete prevention of cardiovascular events and mortality in patients with advanced coronary disease, including those with previous MIs [480-482]. While these measures have been found to stop or reverse progression of coronary atherosclerosis, its seems likely that this low mortality also reflects a favorable impact on risk for, or progression of, $\mathrm{VH} / \mathrm{HF}$, that is independent of improved coronary perfusion.

While whole-food low-fat plant-based diets tend to be exceedingly low in saturated fat, they are also relatively low in bioavailable phosphate, owing to the fact that much of their phosphate content is tied up in phytates that are poorly digestible [483,484]. Diets high in bioavailable phosphate promote calcification of arterial media as well as heart valves-factors which can increase VH risk by boosting afterload [485-488]. Additionally, high intakes of absorbable phosphate prompt a compensatory increase in bone production of the phosphaturic hormone FGF23 [489,490]. FGF23 is one of those hormones that, 
like angiotensin II or endothelin, can act on cardiomyocytes to activate PLC and thereby promote $\mathrm{VH} / \mathrm{HF}$ [8]. Third-World populations consuming quasi-vegan diets low in phosphate additives are characterized by plasma FGF23 levels remarkably lower than those seen in Western populations [491,492]. Since phosphate additives are widely used in convenience foods, it is desirable to avoid these in order to moderate dietary phosphate absorption [493,494].

Plant-based diets that are relatively low in protein may also protect the heart by boosting plasma levels of fibroblast growth factor 12 (FGF21). A recent study found that, when a diet providing $8 \%$ of calories was fed in ad libitum amounts for 6 weeks to human volunteers, plasma FGF21 levels doubled; this effect may reflect hepatic activation of the kinase GCN2, which is activated by relative deficiencies of essential amino acids $[495,496]$. When obese subjects (BMI > 35) were excluded, the plasma FGF21 levels of long-term vegans were found to be about 3-fold higher than those of omnivores [497]. GCN2 promotes transcription of the FGF21 gene by increasing expression of the ATF4 transcription factor [498]. Recent studies show that cardiomyocytes are responsive to the hormone FGF21 via FGFR1/ $\beta$-klotho receptors, and that this hormone is protective in rodent models of VH/HF [499-503]. Moreover, transgenic mice which overexpress FGF21 enjoy an extension of maximal lifespan comparable to that seen in mice subjected to marked caloric restriction-hence FGF21 has been referred to as "the longevity hormone" [504-506]. Whereas the protein content of most Western diets is considerably higher than $8 \%$, the Okinawan people, while following their traditional quasi-vegan diet back in the 1950s, consumed about $9 \%$ protein calories-and were subsequently characterized by the highest proportion of centenarians in the world [507]. A wholly plant-based diet that provides a significant proportion of its calories from low-protein foods such as fruit, tubers, olives, avocado, and oils, and that is not unduly high in legumes and soy products can be expected to be sufficiently low in protein to promote FGF21 production. Moreover, plant protein, as opposed to animal protein, tends to be relatively low in certain essential amino acids (notably methionine and lysine); hence, a low-protein diet featuring plant protein can be expected to activate GCN2 more effectively than a diet of comparable protein content featuring animal protein [508].

GCN2, like the ER stress-activated kinase PERK, is a kinase for eIF2 $\alpha$ [509]. Through this mechanism, both GCN2 and PERK help to control ER stress by slowing the synthesis of many proteins, while increasing the transcription of others that are protective in this regard [510]. However, they also boost expression of $\mathrm{CHOP}$, a protein which is proapoptotic [213]. The net impact of eIF2 $\alpha$ phosphorylation on VH/HF is the subject of conflicting reports; activation of GCN2 with the drug halofuginone, or up-regulation of eIF $2 \alpha$ phosphorylation with the phosphatase inhibitor salubrinal, have been found to protect the heart from pressure overload [511-515] — whereas mice with genetic knockout of GCN2 have also been reported to be protected in this regard [516]. Hence, whereas moderate protein restriction might be expected to benefit VH/HF via increased FGF21 activity, the effect of directly activating GCN2 in cardiomyocytes is more equivocal. Animal studies are needed to test the impact of moderate protein restriction in rodent models of $\mathrm{VH} / \mathrm{HF}$.

Long-term vegans tend to be notably leaner than either vegetarians or omnivores; a thermogenic effect of FGF21 may be partially responsible for this finding [495,496,517-520]. Additionally, independent of body weight, vegans are at notably lower risk for type two diabetes [521,522]. Hence, a plant-based diet may have a favorable impact on two key risk factors for $\mathrm{VH} / \mathrm{HF}$ - obesity and diabetes.

It appears likely that a low-fat plant-based diet can favorably influence flow-mediated vasodilation [523-526]. This may help to explain the fairly rapid impact of such a diet on anginal symptoms in patients with coronary stenosis (regression of stenotic lesions is only seen after many months of such a diet), and would be expected to provide symptomatic benefit in HF. 
Although the impact of long-term consumption of plant-based diets per se on risk for HF has not been assessed to-date, prospective studies have observed that a Mediterraneanstyle diet is protective in this regard, that whole grains are associated with protection whereas red meat, egg and dairy product consumption correlates with increased risk, and that high plasma vitamin $C$ levels-likely serving as a marker for fruit and vegetable intake-predict decreased risk for HF [527-531].

Moreover, the first case report linking adoption of a wholly plant-based diet with improved control of HF has appeared [532]. The 79-year-old patient presented with 3 -vessel coronary disease, aortic regurgitation, a 35\% ejection fraction, and dyspnea upon exertion; he was already medicated with atenolol, candesartan, and low-dose aspirin. Declining coronary bypass and valve replacement therapy, he adopted a plant-based diet that excluded all animal products. After two months on this diet, in addition to an 18 pound weight loss and marked improvements in serum lipids, his dyspnea was eased to the point that he could adopt a regular aerobic exercise program. At the 3.5 month point, an echocardiogram revealed that his ejection fraction had increased to $50 \%$. A formal trial of this diet-based strategy for management of HF may be warranted.

Wholly plant-based diets require supplementation with vitamin B12, as is well known. Such diets are also devoid of carnitine and taurine, two factors potentially beneficial for the failing heart. Whereas humans can synthesize these factors themselves, their tissue levels in vegans tend to be somewhat lower than in omnivores [533,534]. Hence, carnitine and taurine supplementation may be particularly recommendable in VH/HF patients following a strictly plant-based diet.

In individuals who are salt-sensitive, salty diets provoke an increase in intravascular volume that is compensated by increased adrenal production of the natriuretic factor marinobufagenin (MBG) [535]. Curiously, this hormone (also produced in the sweat glands of toxic toads-hence its name!) can interact with plasma membrane sodium-potassium ATPases (a.k.a. "the sodium pump") which express alpha1 subunits, both to inhibit pump action, and to induce intracellular signaling [536-538]. In kidney tubules, MBG exerts a compensatory natriuretic effect, presumably reflecting the role of the sodium pump in sodium retention [539]. In vascular smooth muscle, it promotes vasoconstriction by increasing intracellular sodium; this in turn boosts intracellular free calcium by stimulating the plasma membrane sodium/calcium exchanger [536,540]. (The structurally homologous sodium pump inhibitor ouabain exerts its inotropic effect on cardiomyocytes via a similar mechanism [541]) This effect likely rationalizes the pro-hypertensive effects of salty diets on salt-sensitive people and rodents [542]. However, MBG can also exert a hormonal effect on other tissues via the sodium pump-in particular, MBG can act directly on cardiac fibroblasts to activate intracellular signaling that promotes their conversion to myofibroblasts and boosts their collagen production $[537,543,544]$. The possibility that MBG might also act on coronary endothelium to suppress its production of $\mathrm{NO}$ via a pro-oxidant effect, merits consideration [545]. Epidemiological studies demonstrate an increased risk for LVH in salt-sensitive subjects and in those eating relatively salty diets, independent of blood pressure; MBG appears likely to be a mediator of this effect [546-549]. Moderation in dietary salt intake may therefore help prevent VH/HF. It should be noted however, that severe salt restriction can exert a countervailing adverse effect on the heart by boosting sympathetic and renin-angiotensin activity; that might explain why correlations between dietary sodium intake and mortality show a U-shaped pattern in some studies $[550,551]$. This also explains why drugs antagonizing angiotensin II activity increase the utility of dietary sodium reduction for hypertension control [552].

With respect to potassium, it is known that increased dietary potassium can exert a natriuretic effect in the context of salty diets; it is logical to suspect that this effect could decrease MBG production, although this possibility has not been evaluated [553]. In the Strong Heart Study, the sodium/potassium ratio correlated significantly with left ventricular mass; an inverse correlation with potassium per se did not achieve statistical significance [554]. In overview, moderation in the use of added salt-perhaps abetted by 
the use of modified salts that are potassium-enriched [555,556] — coupled with an ample intake of potassium-rich natural foods, appears to be a wise policy for prevention/control of $\mathrm{VH} / \mathrm{HF}$ and for protection of cardiovascular health more generally.

It is well documented that regular exercise training can provide symptomatic benefit in HF [557-559]. This is at least partially attributable to the favorable impact of episodes of increased shear stress on the function of vascular endothelium, promoting efficient flow-mediated vasodilation; this helps to compensate for the adverse impact of chronically decreased cardiac output on endothelial function [560-562]. Intriguingly, sauna can exert a comparable effect on vascular endothelium, and regular sauna treatments have been shown to benefit HF patients [75,563-568]. Sauna may be a good alternative for patients in whom significant aerobic exercise is too taxing; however, it can also be used in conjunction with exercise training to achieve better results [566]. Perhaps it should not surprise us that, in the general Finnish population, regular sauna bathing is associated with decreased overall and cardiovascular mortality—paralleling the effects of regular exercise [569].

\section{Summing Up}

To review in brief the measures discussed here which appear to merit consideration for inclusion in nutraceutical/dietary/lifestyle programs for preventing and controlling $\mathrm{VH} / \mathrm{HF}$ :

PhyCB could be employed to suppress oxidant stress stemming from Nox2- and Nox4-dependent NADPH oxidase complexes. CoQ may decrease oxidative stress of mitochondrial origin by accepting electrons from complex I-the chief mitochondrial site of superoxide production in $\mathrm{VH} / \mathrm{HF}$ - and by its direct scavenging activity; it might also aid the efficiency of ATP production by cardiomyocyte mitochondria. Astaxanthin may limit mitochondrial superoxide generation by protecting the mitochondrial inner membrane and respiratory chain from cumulative oxidant damage. NAC supplementation should boost cellular levels of glutathione, which acts in various way to counteract the impact of hydrogen peroxide on cellular signaling. Phase 2 inducers such as lipoic acid or the widely distributed phytochemical ferulic acid should likewise be useful in this regard, while inducing increased expression of an array of antioxidant enzymes. Melatonin can up-regulate phase 2 induction by boosting Nrf2 expression, while also opposing TGF $\beta$ mediated cardiac fibrosis by induction of Sirt1. Zinc may provide antioxidant protection via induction of metallothionein — a natural antagonist of cadmium toxicity—and possibly methionine sulfoxide reductase-A as well. Correcting selenium deficiency should ensure adequate expression of protective peroxidase and thioreductase activities.

While control of oxidative stress will blunt a key stimulant of ER stress, the latter can also be addressed with TUDCA, which aids efficient and proper protein folding. Berberine, an activator of AMPK, can also combat ER stress, by slowing the rate of protein synthesis via down-regulation of eEF2 activity.

Promoting recoupling of NOS should be beneficial both for supporting effective NO synthesis, and for quelling superoxide production. This may be achieved with supplemental citrulline - to offset the inhibitory/uncoupling activity of ADMA-and possibly high-dose folate, which may boost expression of dihydrofolate reductase to promote reduction of oxidized tetrahydrobiopterin, and may also protect tetrahydrobiopterin from oxidation. High-dose biotin may mimic the signaling impact of NO via direct stimulation of soluble guanylate cyclase. Soy isoflavones, via activation of ER $\beta$, should boost expression and activity of eNOS in cardiac tissue. Cocoa flavanols and hawthorn OPCs up-regulate eNOS activity in vascular endothelium, thereby improving endothelium-dependent vasodilation and decreasing left ventricular afterload. Production of protective $\mathrm{H}_{2} \mathrm{~S}$ could be promoted by supplemental NAC, and recent evidence also suggests that taurine also might have utility in that regard. In any case, taurine exerts a worthwhile positive inotropic impact on hear function in HF that appears to be safe.

An ample intake of EPA, particularly in the context of a low-fat diet, may oppose cardiac fibrosis through activation of fibroblast GPR120 receptors. Achieving an adequate 
membrane content of EPA/DHA, and a high ratio of EPA/AA in membranes and plasma lipids, can also be expected to protect $\mathrm{VH} / \mathrm{HF}$ patients by decreasing their elevated risk for sudden death arrthymias and stabilizing their coronary plaque.

Insuring that $\mathrm{Mg}$ levels in cardiomyocytes are in the high-normal range may curb to a modest degree the elevated calcium-mediated signaling in VH/HF by competing with free calcium for binding to calmodulin and possibly other calcium-activated proteins. The orotate salt of $\mathrm{Mg}$ has shown particular clinical activity in $\mathrm{HF}$, possibly because orotate supplementation boosts cardiomyocyte levels of carnosine, which has antioxidant, membrane protective, and acid-buffering properties. The utility of carnitine supplementation in $\mathrm{VH} / \mathrm{HF}$ may also reflect control of intracellular acidity, as, in the context of relative hypoxia, carnitine acts to disinhibit pyruvate dehydrogenase, directing more pyruvate to oxidation as opposed to lactic acid generation. Via activation of plasma membrane chloride channels, supplemental glycine may moderate the calcium influx through myocardial L-type calcium channels that plays a key role in the over-activation of NFAT and CaMKII driving the VH/HF syndrome. Copper supplementation may support effective myocardial angiogenesis, helping to ward off the microvascular rarefication that that plays a key role in the transition of $\mathrm{VH}$ to HF.

A plant-based diet low in saturated fats may diminish the heart's exposure to saturated fatty acids, thereby lessening the adverse impact of metabolic syndrome/obesity/diabetes on progression of VH/HF. Such as diet-particularly if phosphate food additives are concurrently avoided-should also lessen the adverse impact of FGF23 on the heart by moderating phosphate absorption. Conversely, a plant-based diet of moderate protein content could be expected to protect the heart by enhancing FGF21 production. While moderate protein restriction might also lessen myocardial ER stress by activating GCN2, this could also be expected to increase production of the pro-apoptotic transcription factor $\mathrm{CHOP}$; hence, the direct impact of protein restriction on the heart in $\mathrm{VH} / \mathrm{HF}$ requires further study. In people who are salt-sensitive, moderating dietary salt intake should protect the heart by decreasing plasma levels of MBG, a natriuretic factor that promotes cardiac fibrosis. Whether increased dietary potassium might blunt the adverse impact of sodium chloride in this regard, merits consideration. HF is characterized by impaired endothelial function, since decreased cardiac output lessens protective shear stress; this in turn increases the heart's workload. Regular exercise training or sauna bathing may help to correct this problem by exposing the vasculature to episodic increases in shear stress.

Many of the measures discussed here are recommended on theoretical grounds, including rodent studies. However, it should be noted that $\mathrm{CoQ}$, berberine, citrulline, taurine, $\mathrm{Mg}$ orotate, exercise, and sauna have received greater or lesser degrees of clinical confirmation in controlled studies targeting HF patients. Table 1 provides rough "guesstimates" of the clinically useful doses of various nutraceuticals that have potential for VH/HF control. The dose ranges provided have been found to exert physiological effects in clinical research.

Table 1. Nutraceuticals for Prevention and Control of VH/HF—Suggested Daily Doses.

\begin{tabular}{cc}
\hline Phycocyanobilin. & $100 \mathrm{mg}$ (or 15 g spirulina) [140,570]. \\
\hline N-Acetylcysteine & $1200-1800 \mathrm{mg}[152]$. \\
\hline Lipoic Acid & $1200-1800 \mathrm{mg}$ and/or Ferulic Acid 250-1000 mg [571-573]. \\
\hline Zinc & $30-80 \mathrm{mg}$ (complemented by copper, 1-2 mg) [184,574]. \\
\hline Selenium & $100-200 \mathrm{mcg}[189,193]$. \\
\hline Ubiquinol & $300 \mathrm{mg}[575,576]$. \\
\hline Astaxanthin & $10-20 \mathrm{mg}[577,578]$. \\
\hline Melatonin & $5-20 \mathrm{mg}$ (at bedtime) [579,580]. \\
\hline TUDCA & $2-4 \mathrm{~g}[581]$. \\
\hline
\end{tabular}


Table 1. Cont.

\begin{tabular}{cc}
\hline Berberine & $1000-2000 \mathrm{mg}[582]$. \\
\hline EPA & $1-2$ g daily [583]. \\
\hline Magnesium & $200-400 \mathrm{mg}[584]$. \\
\hline Mg Orotate & $3-4 \mathrm{~g} \mathrm{[390].}$ \\
\hline Citrulline & $3 \mathrm{~g}[585,586]$. \\
\hline Folate & $40-80 \mathrm{mg}[247]$. \\
\hline Na or K Nitrate & $20-40 \mathrm{mg}[589,590]$. \\
\hline Biotin & $100 \mathrm{mg}[591,592]$. \\
\hline Soy Isoflavones & $400-1000 \mathrm{mg}[593,594]$. \\
\hline Cocoa flavanols & $2-6 \mathrm{~g}[407,415]$. \\
\hline Taurine & $2-4 \mathrm{~g}[399]$. \\
\hline Carnitine & $10-15 \mathrm{~g}[595,596]$. \\
\hline Glycine & $2-8 \mathrm{mg}[431,597]$. \\
\hline Copper &
\end{tabular}

There is evidently considerable scope for the development of functional foods and complex supplements which could make it more convenient and less expensive to ingest a number of nutraceuticals of potential benefit in VH/HF. Such supplements would not be expected to contain all of the agents discusses here, as there evidently will be a point of diminishing returns with respect to the net benefit achieved by addressing a specific target-i.e., a person who is employing 2 or 3 agents that boost NO bioactivity might derive little further benefit from expanding that list to 5 . The strategy of employing multiple nutraceuticals for management of HF has been suggested previously by other analysts [598-601]. Indeed, a supplementation regimen providing CoQ10, taurine, and carnitine has been shown to decrease LV end diastolic volume in patients with diminished ejection fraction awaiting coronary bypass surgery [600]. The beneficial effects of multivitamin-mineral supplementation on LV function in HF patients were noted above [430]. Table 2 suggests a way to configure the suggested nutraceuticals into a practical program of supplementation.

It should be noted that, whereas the agents and measures discussed in this essay have targeted the $\mathrm{VH} / \mathrm{HF}$ syndrome, some of them likely would also work to promote vascular health in other, complementary ways: opposing atherogenesis, stabilizing plaque, preventing vascular calcification and aneurysms, moderating systemic and pulmonary blood pressure, and controlling platelet aggregation. This reflects the fact that oxidative and ER stress, insufficient $\mathrm{NO}$ or $\mathrm{H}_{2} \mathrm{~S}$ bioactivity, and magnesium deficit contribute in various ways to these vascular pathologies [376,584,602-636]. Moreover, these factors also contribute to the adipocyte dysfunction-hypertrophy, insulin resistance, elevated production of pro-inflammatory adipokines and diminished production of adiponectin-that underlie the metabolic syndrome and diabetes, key drivers of vascular disease [637-660]. Additionally, glycine, FGF21-boosting plant-based diets, and aerobic exercise training can be expected to favorably influence adipocyte function and insulin sensitivity $[649,661-667]$. With respect to berberine, it also acts to lower LDL cholesterol—through a mechanism that is complementary to that of statins [668,669] — and can be used in combination with monacolin-rich red yeast rice as a well-tolerated nutraceutical alternative to prescription statins [670]. 
Table 2. Practical Guidance for Heart-Protective Supplementation.

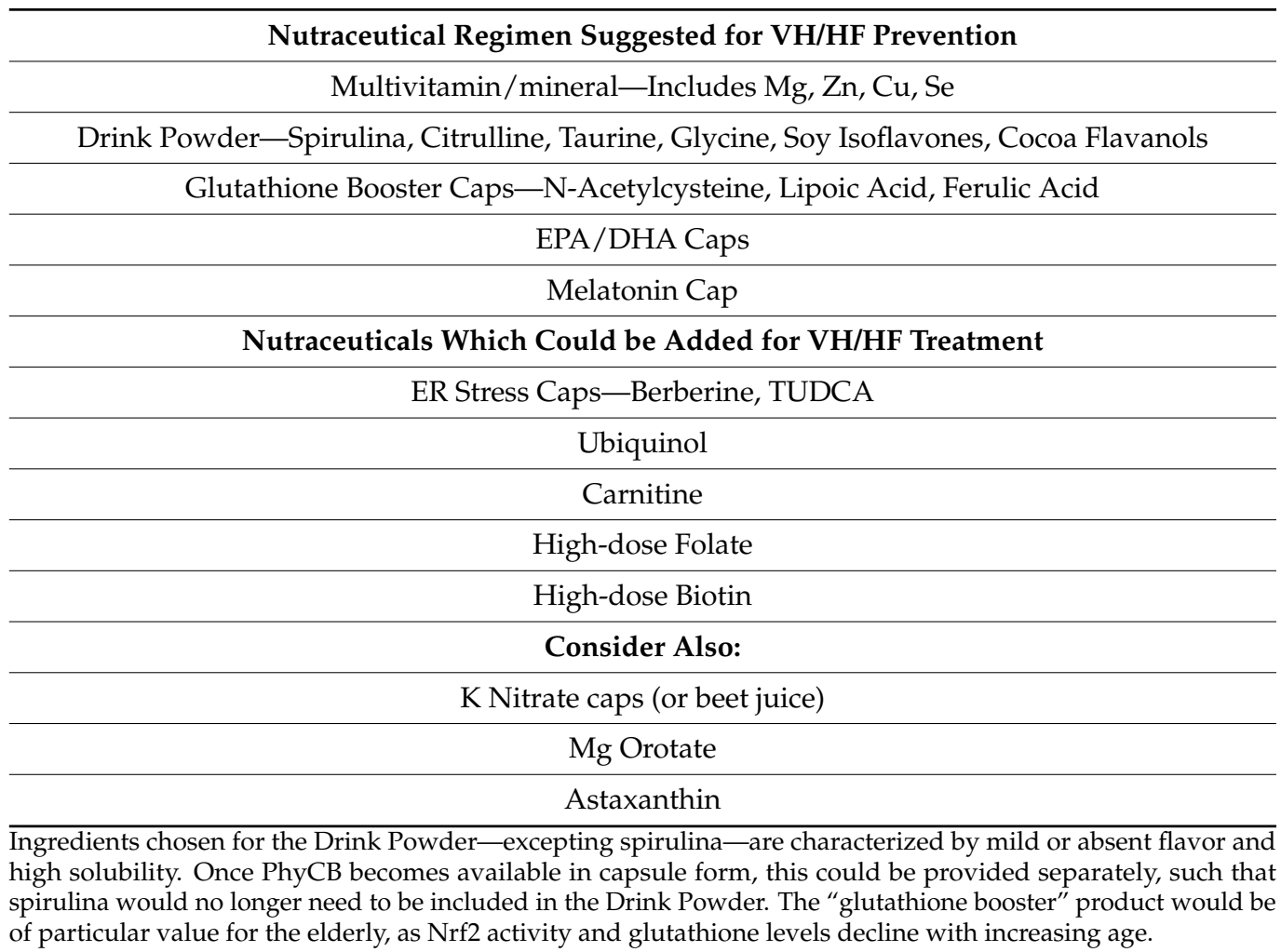

Funding: This research received no external funding.

Conflicts of Interest: The authors declare no conflict of interest.

\section{References}

1. Bai, H.; Wu, L.L.; Xing, D.Q.; Liu, J.; Zhao, Y.L. Angiotensin II induced upregulation of G alpha q/11, phospholipase C beta 3 and extracellular signal-regulated kinase 1/2 via angiotensin II type 1 receptor. Chin. Med. J. 2004, 117, 88-93.

2. Onohara, N.; Nishida, M.; Inoue, R.; Kobayashi, H.; Sumimoto, H.; Sato, Y.; Mori, Y.; Nagao, T.; Kurose, H. TRPC3 and TRPC6 are essential for angiotensin II-induced cardiac hypertrophy. EMBO J. 2006, 25, 5305-5316. [CrossRef] [PubMed]

3. Gómez, A.M.; Ruiz-Hurtado, G.; Benitah, J.-P.; Domínguez-Rodríguez, A. Ca(2+) fluxes involvement in gene expression during cardiac hypertrophy. Curr. Vasc. Pharmacol. 2013, 11, 497-506. [CrossRef] [PubMed]

4. Fujita, T.; Toya, Y.; Iwatsubo, K.; Onda, T.; Kimura, K.; Umemura, S.; Ishikawa, Y. Accumulation of molecules involved in $\alpha 1$-adrenergic signal within caveolae: Caveolin expression and the development of cardiac hypertrophy. Cardiovasc. Res. 2001, 51, 709-716. [CrossRef]

5. Lamers, J.M.; De Jonge, H.W.; Panagia, V.; Van Heugten, H.A. Receptor-mediated signalling pathways acting through hy-drolysis of membrane phospholipids in cardiomyocytes. Cardioscience 1993, 4, 121-131.

6. Ruwhof, C.; van Wamel, J.T.; Noordzij, L.A.; Aydin, S.; Harper, J.C.; van der Laarse, A. Mechanical stress stimulates phos-pholipase C activity and intracellular calcium ion levels in neonatal rat cardiomyocytes. Cell Calcium 2001, 29, 73-83. [CrossRef]

7. Schiekel, J.; Lindner, M.; Hetzel, A. The inhibition of the potassium channel TASK-1 in rat cardiac muscle by endo-thelin-1 is mediated by phospholipase C. Cardiovasc. Res. 2013, 97, 97-105. [CrossRef]

8. Grabner, A.; Amaral, A.P.; Schramm, K.; Singh, S.; Sloan, A.; Yanucil, C.; Li, J.; Shehadeh, L.A.; Hare, J.M.; David, V.; et al. Activation of Cardiac Fibroblast Growth Factor Receptor 4 Causes Left Ventricular Hypertrophy. Cell Metab. 2015, 22, 1020-1032. [CrossRef]

9. Fu, Q.; Chen, X.; Xiang, Y.K. Compartmentalization of beta-adrenergic signals in cardiomyocytes. Trends Cardiovasc. Med. 2013, 23, 250-256. [CrossRef] [PubMed]

10. Nishida, M.; Sato, Y.; Uemura, A. P2Y6 receptor-Galpha12/13 signalling in cardiomyocytes triggers pressure over-load-induced cardiac fibrosis. EMBO J. 2008, 27, 3104-3115. [CrossRef] [PubMed]

11. Yamamoto, S.; Ichishima, K.; Ehara, T. Regulation of Extracellular UTP-Activated Cl- Current by P2Y-PLC-PKC Signaling and ATP Hydrolysis in Mouse Ventricular Myocytes. J. Physiol. Sci. 2007, 57, 85-94. [CrossRef] [PubMed]

12. D'Angelo, D.D.; Sakata, Y.; Lorenz, J.N.; Boivin, G.P.; Walsh, R.A.; Liggett, S.B.; Dorn, G.W. Transgenic G q overexpression induces cardiac contractile failure in mice. Proc. Natl. Acad. Sci. USA 1997, 94, 8121-8126. [CrossRef] 
13. Niizeki, T.; Takeishi, Y.; Kitahara, T. Diacylglycerol kinase-epsilon restores cardiac dysfunction under chronic pressure overload: A new specific regulator of Galpha(q) signaling cascade. Am. J. Physiol. Heart Circ. Physiol. 2008, 295, H245-H255. [CrossRef] [PubMed]

14. Hofmann, T.; Obukhov, A.G.; Schaefer, M.; Harteneck, C.; Gudermann, T.; Schultz, G. Direct activation of human TRPC6 and TRPC3 channels by diacylglycerol. Nat. Cell Biol. 1999, 397, 259-263. [CrossRef]

15. Makarewich, C.A.; Zhang, H.; Davis, J.; Correll, R.N.; Trappanese, D.M.; Hoffman, N.E.; Troupes, C.D.; Berretta, R.M.; Kubo, H.; Madesh, M.; et al. Transient Receptor Potential Channels Contribute to Pathological Structural and Functional Remodeling after Myocardial Infarction. Circ. Res. 2014, 115, 567-580. [CrossRef]

16. Gao, H.; Wang, F.; Wang, W.; Makarewich, C.A.; Zhang, H.; Kubo, H.; Berretta, R.M.; Barr, L.A.; Molkentin, J.D.; Houser, S.R. $\mathrm{Ca}^{2+}$ influx through L-type $\mathrm{Ca}^{2+}$ channels and transient receptor potential channels activates pathological hypertrophy signaling. J. Mol. Cell. Cardiol. 2012, 53, 657-667. [CrossRef] [PubMed]

17. Wu, X.; Eder, P.; Chang, B.; Molkentin, J.D. TRPC channels are necessary mediators of pathologic cardiac hypertrophy. Proc. Natl. Acad. Sci. USA 2010, 107, 7000-7005. [CrossRef]

18. Eder, P. Cardiac Remodeling and Disease: SOCE and TRPC Signaling in Cardiac Pathology. Adv. Exp. Med. Biol. 2017, 993, 505-521. [PubMed]

19. Nichols, C.B.; Rossow, C.F.; Navedo, M.F.; Westenbroek, R.E.; Catterall, W.A.; Santana, L.F.; McKnight, G.S. Sympathetic Stimulation of Adult Cardiomyocytes Requires Association of AKAP5 With a Subpopulation of L-Type Calcium Channels. Circ. Res. 2010, 107, 747-756. [CrossRef]

20. Kuriyama, M.; Matsushita, M.; Tateishi, A.; Moriwaki, A.; Tomizawa, K.; Ishino, K.; Sano, S.; Matsui, H. A Cell-permeable NFAT Inhibitor Peptide Prevents Pressure-Overload Cardiac Hypertrophy. Chem. Biol. Drug Des. 2006, 67, 238-243. [CrossRef]

21. Kuwahara, K.; Wang, Y.; McAnally, J. TRPC6 fulfills a calcineurin signaling circuit during pathologic cardiac re-modeling. J. Clin. Investig. 2006, 116, 3114-3126. [CrossRef] [PubMed]

22. Pereira, L.; Cheng, H.; Lao, D.H. Epac2 mediates cardiac beta1-adrenergic-dependent sarcoplasmic reticulum Ca ${ }^{2+}$ leak and arrhythmia. Circulation 2013, 127, 913-922. [CrossRef] [PubMed]

23. Bobin, P.; Varin, A.; Lefebvre, F.; Fischmeister, R.; Vandecasteele, G.; Leroy, J. Calmodulin kinase II inhibition limits the proarrhythmic $\mathrm{Ca}^{2+}$ waves induced by cAMP-phosphodiesterase inhibitors. Cardiovasc. Res. 2016, 110, 151-161. [CrossRef]

24. Erickson, J.R.; Joiner, M.L.; Guan, X. A dynamic pathway for calcium-independent activation of CaMKII by methionine oxidation. Cell 2008, 133, 462-474. [CrossRef]

25. Purohit, A.; Rokita, A.G.; Guan, X.; Chen, B.; Koval, O.M.; Voigt, N.; Neef, S.; Sowa, T.; Gao, Z.; Luczak, E.D.; et al. Oxidized $\mathrm{Ca}^{2+} /$ Calmodulin-Dependent Protein Kinase II Triggers Atrial Fibrillation. Circulation 2013, 128, 1748-1757. [CrossRef]

26. Anderson, M.E. Oxidant stress promotes disease by activating CaMKII. J. Mol. Cell. Cardiol. 2015, 89, 160-167. [CrossRef] [PubMed]

27. Backs, J.; Song, K.; Bezprozvannaya, S.; Chang, S.; Olson, E.N. CaM kinase II selectively signals to histone deacetylase 4 during cardiomyocyte hypertrophy. J. Clin. Investig. 2006, 116, 1853-1864. [CrossRef] [PubMed]

28. Bossuyt, J.; Helmstadter, K.; Wu, X. Ca ${ }^{2+} /$ calmodulin-dependent protein kinase IIdelta and protein kinase D over-expression reinforce the histone deacetylase 5 redistribution in heart failure. Circ. Res. 2008, 102, 695-702. [CrossRef]

29. Backs, J.; Backs, T.; Neef, S. The delta isoform of CaM kinase II is required for pathological cardiac hypertrophy and remodeling after pressure overload. Proc. Natl. Acad. Sci. USA 2009, 106, 2342-2347. [CrossRef]

30. Ai, X.; Curran, J.W.; Shannon, T.R.; Bers, D.M.; Pogwizd, S.M. Ca ${ }^{2+} /$ Calmodulin-Dependent Protein Kinase Modulates Cardiac Ryanodine Receptor Phosphorylation and Sarcoplasmic Reticulum Ca ${ }^{2+}$ Leak in Heart Failure. Circ. Res. 2005, 97, $1314-1322$. [CrossRef] [PubMed]

31. Fischer, T.H.; Eiringhaus, J.; Dybkova, N. Ca(2+) /calmodulin-dependent protein kinase II equally induces sarco-plasmic reticulum $\mathrm{Ca}(2+)$ leak in human ischaemic and dilated cardiomyopathy. Eur. J. Heart Fail. 2014, 16, 1292-1300. [CrossRef]

32. Westenbrink, B.D.; Ling, H.; Divakaruni, A.S. Mitochondrial reprogramming induced by CaMKIIdelta mediates hy-pertrophy decompensation. Circ. Res. 2015, 116, e28-e39. [CrossRef] [PubMed]

33. Joiner, M.-L.A.; Koval, O.M.; Li, J.; He, B.J.; Allamargot, C.; Gao, Z.; Luczak, E.D.; Hall, D.D.; Fink, B.D.; Chen, B.; et al. CaMKII determines mitochondrial stress responses in heart. Nat. Cell Biol. 2012, 491, 269-273. [CrossRef] [PubMed]

34. Fieni, F.; Johnson, D.E.; Hudmon, A.; Kirichok, Y. Mitochondrial $\mathrm{Ca}^{2+}$ uniporter and CaMKII in heart. Nat. Cell Biol. 2014, 513, E1-E2. [CrossRef] [PubMed]

35. Charnet, P.; Lory, P.; Bourinet, E.; Collin, T.; Nargeot, J. cAMP-dependent phosphorylation of the cardiac L-type Ca channel: A missing link? Biochimie 1995, 77, 957-962. [CrossRef]

36. Kamp, T.J.; Hell, J.W. Regulation of Cardiac L-Type Calcium Channels by Protein Kinase A and Protein Kinase C. Circ. Res. 2000, 87, 1095-1102. [CrossRef]

37. Zhou, P.; Zhao, Y.T.; Guo, Y.B. Beta-adrenergic signaling accelerates and synchronizes cardiac ryanodine receptor response to a single L-type Ca2+ channel. Proc. Natl. Acad. Sci. USA 2009, 106, 18028-18033. [CrossRef]

38. Shan, J.; Kushnir, A.; Betzenhauser, M.J.; Reiken, S.; Li, J.; Lehnart, S.E.; Lindegger, N.; Mongillo, M.; Mohler, P.J.; Marks, A.R. Phosphorylation of the ryanodine receptor mediates the cardiac fight or flight response in mice. J. Clin. Investig. 2010, 120, 4388-4398. [CrossRef]

39. Colyer, J. Phosphorylation states of phospholamban. Ann. N. Y. Acad. Sci. 1998, 853, 79-91. [CrossRef] 
40. Hagemann, D.; Xiao, R.P. Dual site phospholamban phosphorylation and its physiological relevance in the heart. Trends Cardiovasc. Med. 2002, 12, 51-56. [CrossRef]

41. Dolmatova, E.; Spagnol, G.; Boassa, D. Cardiomyocyte ATP release through pannexin 1 aids in early fibroblast ac-tivation. Am. J. Physiol. Heart Circ. Physiol. 2012, 303, H1208-H1218. [CrossRef]

42. Phrommintikul, A.; Tran, L.; Kompa, A. Effects of a Rho kinase inhibitor on pressure overload induced cardiac hy-pertrophy and associated diastolic dysfunction. Am. J. Physiol. Heart Circ. Physiol. 2008, 294, H1804-H1814. [CrossRef]

43. Shimizu, T.; Liao, J.K. Rho Kinases and Cardiac Remodeling. Circ. J. 2016, 80, 1491-1498. [CrossRef]

44. He, Z.; Yang, Y.; Wen, Z. CYP2J2 metabolites, epoxyeicosatrienoic acids, attenuate Ang II-induced cardiac fibrotic response by targeting Galpha12/13. J. Lipid Res. 2017, 58, 1338-1353. [CrossRef]

45. Cucoranu, I.; Clempus, R.; Dikalova, A. NAD(P)H oxidase 4 mediates transforming growth factor-beta1-induced differentiation of cardiac fibroblasts into myofibroblasts. Circ. Res. 2005, 97, 900-907. [CrossRef]

46. Yeh, Y.H.; Kuo, C.T.; Chang, G.J.; Qi, X.Y.; Nattel, S.; Chen, W.J. Nicotinamide adenine dinucleotide phosphate oxidase 4 mediates the differential responsiveness of atrial versus ventricular fibroblasts to transforming growth factor-beta. Circ. Arrhythm. Electrophysiol. 2013, 6, 790-798. [CrossRef] [PubMed]

47. Masuyama, H.; Tsuruda, T.; Sekita, Y.; Hatakeyama, K.; Imamura, T.; Kato, J.; Asada, Y.; Stasch, J.-P.; Kitamura, K. Pressureindependent effects of pharmacological stimulation of soluble guanylate cyclase on fibrosis in pressure-overloaded rat heart. Hypertens. Res. 2009, 32, 597-603. [CrossRef] [PubMed]

48. Li, P.; Wang, D.; Lucas, J. Atrial natriuretic peptide inhibits transforming growth factor beta-induced Smad signaling and myofibroblast transformation in mouse cardiac fibroblasts. Circ. Res. 2008, 102, 185-192. [CrossRef] [PubMed]

49. Sawada, N.; Itoh, H.; Yamashita, J. cGMP-dependent protein kinase phosphorylates and inactivates RhoA. Biochem. Biophys. Res. Commun. 2001, 280, 798-805. [CrossRef] [PubMed]

50. Chau, V.Q.; Salloum, F.N.; Hoke, N.N.; Abbate, A.; Kukreja, R.C. Mitigation of the progression of heart failure with sildenafil involves inhibition of RhoA/Rho-kinase pathway. Am. J. Physiol. Heart Circ. Physiol. 2011, 300, H2272-H2279. [CrossRef]

51. Matsuzaki, S.; Hiratsuka, T.; Taniguchi, M.; Shingaki, K.; Kubo, T.; Kiya, K.; Fujiwara, T.; Kanazawa, S.; Kanematsu, R.; Maeda, T.; et al. Physiological ER Stress Mediates the Differentiation of Fibroblasts. PLoS ONE 2015, 10, e0123578. [CrossRef] [PubMed]

52. Heindryckx, F.; Binet, F.; Ponticos, M. Endoplasmic reticulum stress enhances fibrosis through IRE1alpha-mediated degradation of miR-150 and XBP-1 splicing. EMBO Mol. Med. 2016, 8, 729-744. [CrossRef] [PubMed]

53. Ayala, P.; Montenegro, J.; Vivar, R.; Letelier, A.; Urroz, P.A.; Copaja, M.; Pivet, D.; Humeres, C.; Troncoso, R.; Vicencio, J.M.; et al Attenuation of endoplasmic reticulum stress using the chemical chaperone 4-phenylbutyric acid prevents cardiac fibrosis induced by isoproterenol. Exp. Mol. Pathol. 2012, 92, 97-104. [CrossRef] [PubMed]

54. Luo, T.; Chen, B.; Wang, X. 4-PBA prevents pressure overload-induced myocardial hypertrophy and interstitial fibrosis by attenuating endoplasmic reticulum stress. Chem. Biol. Interact. 2015, 242, 99-106. [CrossRef] [PubMed]

55. Shiojima, I.; Sato, K.; Izumiya, Y.; Schiekofer, S.; Ito, M.; Liao, R.; Colucci, W.S.; Walsh, K. Disruption of coordinated cardiac hypertrophy and angiogenesis contributes to the transition to heart failure. J. Clin. Investig. 2005, 115, 2108-2118. [CrossRef]

56. Jiang, Y.; Reynolds, C.; Xiao, C.; Feng, W.; Zhou, Z.; Rodriguez, W.; Tyagi, S.C.; Eaton, J.W.; Saari, J.T.; Kang, Y.J. Dietary copper supplementation reverses hypertrophic cardiomyopathy induced by chronic pressure overload in mice. J. Exp. Med. 2007, 204, 657-666. [CrossRef]

57. Silberman, G.A.; Fan, T.H.; Liu, H. Uncoupled cardiac nitric oxide synthase mediates diastolic dysfunction. Circulation 2010, 121, 519-528. [CrossRef]

58. Alkaitis, M.S.; Crabtree, M.J. Recoupling the Cardiac Nitric Oxide Synthases: Tetrahydrobiopterin Synthesis and Recycling. Curr Heart Fail. Rep. 2012, 9, 200-210. [CrossRef]

59. Tang, L.; Wang, H.; Ziolo, M.T. Targeting NOS as a therapeutic approach for heart failure. Pharmacol. Ther. 2014, 142, 306-315. [CrossRef]

60. Umar, S.; van der Laarse, A. Nitric oxide and nitric oxide synthase isoforms in the normal, hypertrophic, and failing heart. Mol. Cell Biochem. 2010, 333, 191-201. [CrossRef]

61. Gong, W.; Duan, Q.; Cai, Z. Chronic inhibition of cGMP-specific phosphodiesterase 5 suppresses endoplasmic reticulum stress in heart failure. Br. J. Pharmacol. 2013, 170, 1396-1409. [CrossRef]

62. Kruger, M.; Kotter, S.; Grutzner, A. Protein kinase G modulates human myocardial passive stiffness by phosphorylation of the titin springs. Circ. Res. 2009, 104, 87-94. [CrossRef] [PubMed]

63. Kötter, S.; Gout, L.; Von Frieling-Salewsky, M.; Müller, A.E.; Helling, S.; Marcus, K.; Dos Remedios, C.; Linke, W.A.; Krüger, M. Differential changes in titin domain phosphorylation increase myofilament stiffness in failing human hearts. Cardiovasc. Res. 2013, 99, 648-656. [CrossRef] [PubMed]

64. Jin, C.Z.; Jang, J.H.; Kim, H.J.; Wang, Y.; Hwang, I.-C.; Sadayappan, S.; Park, B.M.; Kim, S.H.; Jin, Z.H.; Seo, E.Y.; et al. Myofilament $\mathrm{Ca}^{2+}$ desensitization mediates positive lusitropic effect of neuronal nitric oxide synthase in left ventricular myocytes from murine hypertensive heart. J. Mol. Cell. Cardiol. 2013, 60, 107-115. [CrossRef] [PubMed]

65. Takahashi, S.; Lin, H.; Geshi, N. Nitric oxide-cGMP-protein kinase G pathway negatively regulates vascular transient receptor potential channel TRPC6. J. Physiol. 2008, 586, 4209-4223. [CrossRef] 
66. Koitabashi, N.; Aiba, T.; Hesketh, G.G. Cyclic GMP/PKG-dependent inhibition of TRPC6 channel activity and expression negatively regulates cardiomyocyte NFAT activation Novel mechanism of cardiac stress modulation by PDE5 inhibition. J. Mol. Cell. Cardiol. 2010, 48, 713-724. [CrossRef] [PubMed]

67. Nishida, M.; Watanabe, K.; Sato, Y.; Nakaya, M.; Kitajima, N.; Ide, T.; Inoue, R.; Kurose, H. Phosphorylation of TRPC6 Channels at Thr69 Is Required for Anti-hypertrophic Effects of Phosphodiesterase 5 Inhibition. J. Biol. Chem. 2010, 285, 13244-13253. [CrossRef] [PubMed]

68. Kilic, A.; Velic, A.; De Windt, L.J.; Fabritz, L.; Voss, M.; Mitko, D.; Zwiener, M.; Baba, H.A.; Van Eickels, M.; Schlatter, E.; et al. Enhanced Activity of the Myocardial Na ${ }^{+} / \mathrm{H}^{+}$Exchanger NHE-1 Contributes to Cardiac Remodeling in Atrial Natriuretic Peptide Receptor-Deficient Mice. Circulation 2005, 112, 2307-2317. [CrossRef] [PubMed]

69. Kovacs, A.; Alogna, A.; Post, H.; Hamdani, N. Is enhancing cGMP-PKG signalling a promising therapeutic target for heart failure with preserved ejection fraction? Neth. Heart J. 2016, 24, 268-274. [CrossRef] [PubMed]

70. Yoshioka, K.; Otani, H.; Shimazu, T.; Fujita, M.; Iwasaka, T.; Shiojima, I. Sepiapterin prevents left ventricular hypertrophy and dilatory remodeling induced by pressure overload in rats. Am. J. Physiol. Circ. Physiol. 2015, 309, H1782-H1791. [CrossRef]

71. Kazakov, A.; Müller, P.; Jagoda, P.; Semenov, A.; Böhm, M.; Laufs, U. Endothelial nitric oxide synthase of the bone marrow regulates myocardial hypertrophy, fibrosis, and angiogenesis. Cardiovasc. Res. 2011, 93, 397-405. [CrossRef]

72. Yazawa, H.; Miyachi, M.; Furukawa, M.; Takahashi, K.; Takatsu, M.; Tsuboi, K.; Ohtake, M.; Murase, T.; Hattori, T.; Kato, Y.; et al. Angiotensin-Converting Enzyme Inhibition Promotes Coronary Angiogenesis in the Failing Heart of Dahl Salt-Sensitive Hypertensive Rats. J. Card. Fail. 2011, 17, 1041-1050. [CrossRef]

73. Hambrecht, R.; Fiehn, E.; Weigl, C. Regular physical exercise corrects endothelial dysfunction and improves exercise capacity in patients with chronic heart failure. Circulation 1998, 98, 2709-2715. [CrossRef]

74. Devaux, C.; Iglarz, M.; Richard, V.; Mulder, P.; Henrion, D.; Renet, S.; Henry, J.; Thuillez, C. Chronic decrease in flow contributes to heart failure-induced endothelial dysfunction in rats. Clin. Exp. Pharmacol. Physiol. 2004, 31, 302-305. [CrossRef] [PubMed]

75. Ohori, T.; Nozawa, T.; Ihori, H.; Shida, T.; Sobajima, M.; Matsuki, A.; Yasumura, S.; Inoue, H. Effect of Repeated Sauna Treatment on Exercise Tolerance and Endothelial Function in Patients with Chronic Heart Failure. Am. J. Cardiol. 2012, 109, 100-104. [CrossRef] [PubMed]

76. Polhemus, D.J.; Calvert, J.W.; Butler, J.; Lefer, D.J. The Cardioprotective Actions of Hydrogen Sulfide in Acute Myocardial Infarction and Heart Failure. Science 2014, 2014, 1-8. [CrossRef] [PubMed]

77. Shao, M.; Zhuo, C.; Jiang, R.; Chen, G.; Shan, J.; Ping, J.; Tian, H.; Wang, L.; Lin, C.; Hu, L. Protective effect of hydrogen sulphide against myocardial hypertrophy in mice. Oncotarget 2017, 8, 22344-22352. [CrossRef] [PubMed]

78. Zhang, S.; Pan, C.; Zhou, F.; Yuan, Z.; Wang, H.; Cui, W.; Zhang, G. Hydrogen Sulfide as a Potential Therapeutic Target in Fibrosis. Oxidative Med. Cell. Longev. 2015, 2015, 593407. [CrossRef] [PubMed]

79. Meng, G.; Zhu, J.; Xiao, Y.; Huang, Z.; Zhang, Y.; Tang, X.; Xie, L.; Chen, Y.; Shao, Y.; Ferro, A.; et al. Hydrogen Sulfide Donor GYY4137 Protects against Myocardial Fibrosis. Oxidative Med. Cell. Longev. 2015, 2015, 691070. [CrossRef]

80. Polhemus, D.J.; Kondo, K.; Bhushan, S.; Bir, S.C.; Kevil, C.G.; Murohara, T.; Lefer, D.J.; Calvert, J.W. Hydrogen Sulfide Attenuates Cardiac Dysfunction after Heart Failure Via Induction of Angiogenesis. Circ. Heart Fail. 2013, 6, 1077-1086. [CrossRef]

81. Kondo, K.; Bhushan, S.; King, A.L.; Prabhu, S.D.; Hamid, T.; Koenig, S.; Murohara, T.; Predmore, B.L.; Gojon, G.; Wang, R.; et al. $\mathrm{H}_{2} \mathrm{~S}$ Protects against Pressure Overload-Induced Heart Failure via Upregulation of Endothelial Nitric Oxide Synthase. Circulation 2013, 127, 1116-1127. [CrossRef]

82. Jung, K.-A.; Kwak, M.-K. The Nrf2 System as a Potential Target for the Development of Indirect Antioxidants. Molecules 2010, 15, 7266-7291. [CrossRef]

83. Salazar, M.; Rojo, A.I.; Velasco, D.; de Sagarra, R.M.; Cuadrado, A. Glycogen synthase kinase-3beta inhibits the xenobiotic and antioxidant cell response by direct phosphorylation and nuclear exclusion of the transcription factor Nrf2. J. Biol. Chem. 2006, 281, 14841-14851. [CrossRef]

84. Fujio, Y.; Nguyen, T.; Wencker, D.; Kitsis, R.N.; Walsh, K. Akt Promotes Survival of Cardiomyocytes in Vitro and Protects against Ischemia-Reperfusion Injury in Mouse Heart. Circulation 2000, 101, 660-667. [CrossRef]

85. Funder, J.W. Eplerenone: Hypertension, heart failure and the importance of mineralocorticoid receptor blockade. Future Cardiol. 2006, 2, 535-541. [CrossRef] [PubMed]

86. Johar, S.; Cave, A.C.; Narayanapanicker, A.; Grieve, D.J.; Shah, A.M. Aldosterone mediates angiotensin II-induced interstitial cardiac fibrosis via a Nox2-containing NADPH oxidase. FASEB J. 2006, 20, 1546-1548. [CrossRef] [PubMed]

87. Hayashi, H.; Kobara, M.; Abe, M.; Tanaka, N.; Gouda, E.; Toba, H.; Yamada, H.; Tatsumi, T.; Nakata, T.; Matsubara, H. Aldosterone Nongenomically Produces NADPH Oxidase-Dependent Reactive Oxygen Species and Induces Myocyte Apoptosis. Hypertens. Res. 2008, 31, 363-375. [CrossRef] [PubMed]

88. Lo, C.M.; Carroll, K.S. The redox biochemistry of protein sulfenylation and sulfinylation. J. Biol. Chem. 2013, 288, 26480-26488.

89. Levine, R.L.; Mosoni, L.; Berlett, B.S.; Stadtman, E.R. Methionine residues as endogenous antioxidants in proteins. Proc. Natl. Acad. Sci. USA 1996, 93, 15036-15040. [CrossRef]

90. Suzuki, Y.J.; Cleemann, L.; Abernethy, D.R.; Morad, M. Glutathione is a Cofactor for $\mathrm{H}_{2} \mathrm{O}_{2}-\mathrm{Mediated} \mathrm{Stimulation} \mathrm{of} \mathrm{Ca}^{2+}$-Induced $\mathrm{Ca}^{2+}$ Release in Cardiac Myocytes. Free Radic. Biol. Med. 1998, 24, 318-325. [CrossRef]

91. Anzai, K.; Ogawa, K.; Ozawa, T.; Yamamoto, H. Oxidative Modification of Ion Channel Activity of Ryanodine Receptor. Antioxid. Redox Signal. 2000, 2, 35-40. [CrossRef] [PubMed] 
92. Oda, T.; Yang, Y.; Uchinoumi, H.; Thomas, D.D.; Chen-Izu, Y.; Kato, T.; Yamamoto, T.; Yano, M.; Cornea, R.L.; Bers, D.M. Oxidation of ryanodine receptor (RyR) and calmodulin enhance Ca release and pathologically alter, RyR structure and calmodulin affinity. J. Mol. Cell. Cardiol. 2015, 85, 240-248. [CrossRef] [PubMed]

93. Kuster, G.M.; Lancel, S.; Zhang, J.; Communal, C.; Trucillo, M.P.; Lim, C.C.; Pfister, O.; Weinberg, E.O.; Cohen, R.A.; Liao, R Redox-mediated reciprocal regulation of SERCA and $\mathrm{Na}^{+}-\mathrm{Ca}^{2+}$ exchanger contributes to sarcoplasmic reticulum $\mathrm{Ca}^{2+}$ depletion in cardiac myocytes. Free Radic. Biol. Med. 2010, 48, 1182-1187. [CrossRef] [PubMed]

94. Qin, F.; Siwik, D.A.; Lancel, S.; Zhang, J.; Kuster, G.M.; Luptak, I.; Wang, L.; Tong, X.; Kang, Y.J.; Cohen, R.A.; et al. Hydrogen Peroxide-Mediated SERCA Cysteine 674 Oxidation Contributes to Impaired Cardiac Myocyte Relaxation in Senescent Mouse Heart. J. Am. Heart Assoc. 2013, 2, e000184. [CrossRef] [PubMed]

95. Qin, F.; Siwik, D.A.; Pimentel, D.R.; Morgan, R.J.; Biolo, A.; Tu, V.H.; Kang, Y.J.; Cohen, R.A.; Colucci, W.S. Cytosolic $\mathrm{H}_{2} \mathrm{O}_{2}$ mediates hypertrophy, apoptosis, and decreased SERCA activity in mice with chronic hemodynamic overload. Am. J. Physiol. Circ. Physiol. 2014, 306, H1453-H1463. [CrossRef]

96. Graham, S.; Ding, M.; Ding, Y.; Sours-Brothers, S.; Luchowski, R.; Gryczynski, Z.; Yorio, T.; Ma, H.; Ma, R. Canonical Transient Receptor Potential 6 (TRPC6), a Redox-regulated Cation Channel. J. Biol. Chem. 2010, 285, 23466-23476. [CrossRef]

97. Ding, Y.; Winters, A.; Ding, M.; Graham, S.; Akopova, I.; Muallem, S.; Wang, Y.; Hong, J.H.; Gryczynski, Z.; Yang, S.-H.; et al. Reactive Oxygen Species-mediated TRPC6 Protein Activation in Vascular Myocytes, a Mechanism for Vasoconstrictor-regulated Vascular Tone*. J. Biol. Chem. 2011, 286, 31799-31809. [CrossRef]

98. Chen, C.-A.; Wang, T.-Y.; Varadharaj, S.; Reyes, L.A.; Hemann, C.; Talukder, M.A.H.; Chen, Y.-R.; Druhan, L.J.; Zweier, J.L. S-glutathionylation uncouples eNOS and regulates its cellular and vascular function. Nat. Cell Biol. 2010, 468, 1115-1118. [CrossRef]

99. Wu, F.; Szczepaniak, W.S.; Shiva, S.; Liu, H.; Wang, Y.; Wang, L.; Wang, Y.; Kelley, E.E.; Chen, A.F.; Gladwin, M.T.; et al. Nox2dependent glutathionylation of endothelial NOS leads to uncoupled superoxide production and endothelial barrier dysfunction in acute lung injury. Am. J. Physiol. Cell. Mol. Physiol. 2014, 307, L987-L997. [CrossRef]

100. Milstien, S.; Katusic, Z. Oxidation of Tetrahydrobiopterin by Peroxynitrite: Implications for Vascular Endothelial Function. Biochem. Biophys. Res. Commun. 1999, 263, 681-684. [CrossRef]

101. Kuzkaya, N.; Weissmann, N.; Harrison, D.G.; Dikalov, S. Interactions of peroxynitrite, tetrahydrobiopterin, ascorbic acid, and thiols: Implications for uncoupling endothelial nitric-oxide synthase. J. Biol. Chem. 2003, 278, 22546-22554. [CrossRef] [PubMed]

102. Fritz, B.G.; Hu, X.; Brailey, J.L.; Berry, R.E.; Walker, F.A.; Montfort, W.R. Oxidation and Loss of Heme in Soluble Guanylyl Cyclase fromManduca sexta. Biochemistry 2011, 50, 5813-5815. [CrossRef] [PubMed]

103. Pope, A.J.; Druhan, L.; Guzman, J.E.; Forbes, S.P.; Murugesan, V.; Lu, D.; Xia, Y.; Chicoine, L.G.; Parinandi, N.L.; Cardounel, A.J. Role of DDAH-1 in lipid peroxidation product-mediated inhibition of endothelial NO generation. Am. J. Physiol. Physiol. 2007, 293, C1679-C1686. [CrossRef]

104. Forbes, S.P.; Druhan, L.J.; Guzman, J.E.; Parinandi, N.; Zhang, L.; Green-Church, K.B.; Cardounel, A.J. Mechanism of 4-HNE Mediated Inhibition of hDDAH-1: Implications in No Regulation. Biochemistry 2008, 47, 1819-1826. [CrossRef] [PubMed]

105. Fan, N.-C.; Tsai, C.-M.; Hsu, C.-N.; Huang, L.-T.; Tain, Y.-L. N-Acetylcysteine Prevents Hypertension via Regulation of the ADMA-DDAH Pathway in Young Spontaneously Hypertensive Rats. BioMed Res. Int. 2013, 2013, 696317. [CrossRef] [PubMed]

106. Bartesaghi, S.; Radi, R. Fundamentals on the biochemistry of peroxynitrite and protein tyrosine nitration. Redox Biol. 2018, 14, 618-625. [CrossRef]

107. Qin, F.; Lennon-Edwards, S.; Lancel, S. Cardiac-specific overexpression of catalase identifies hydrogen peroxide-dependent and -independent phases of myocardial remodeling and prevents the progression to overt heart failure in G(alpha)q-overexpressing transgenic mice. Circ. Heart Fail. 2010, 3, 306-313. [CrossRef]

108. De Jong, J.W.; Schoemaker, R.G.; de Jonge, R. Enhanced expression and activity of xanthine oxidoreductase in the failing heart. J. Mol. Cell. Cardiol. 2000, 32, 2083-2089. [CrossRef]

109. Cappola, T.P.; Kass, D.A.; Nelson, G.S. Allopurinol improves myocardial efficiency in patients with idiopathic dilated cardiomyopathy. Circulation 2001, 104, 2407-2411. [CrossRef] [PubMed]

110. Reyes, A.J.; Leary, W.P. Allopurinol or Oxypurinol in Heart Failure Therapy-A Promising New Development or End of Story? Cardiovasc. Drugs Ther. 2005, 19, 311-313. [CrossRef]

111. Adam-Vizi, V.; Starkov, A.A. Calcium and Mitochondrial Reactive Oxygen Species Generation: How to Read the Facts. J. Alzheimer's Dis. 2010, 20, S413-S426. [CrossRef]

112. Zhang, M.; Perino, A.; Ghigo, A.; Hirsch, E.; Shah, A.M. NADPH Oxidases in Heart Failure: Poachers or Gamekeepers? Antioxid. Redox Signal. 2013, 18, 1024-1041. [CrossRef]

113. Liu, Y.; Huang, H.; Xia, W.; Tang, Y.; Li, H.; Huang, C. NADPH oxidase inhibition ameliorates cardiac dysfunction in rabbits with heart failure. Mol. Cell. Biochem. 2010, 343, 143-153. [CrossRef]

114. Liu, Y.; Huang, H.; Tang, Y.H.; Li, H.T.; Wang, X.; Huang, C.X. Effects of NADPH oxidase inhibition on cardiac function and my-ocardial calcium regulatory proteins in rabbits with heart failure. Zhonghua Xin Xue Guan Bing Za Zhi 2009, 37, 883-886.

115. Matsushima, S.; Kinugawa, S.; Yokota, T. Increased myocardial NAD(P)H oxidase-derived superoxide causes the exacerba-tion of postinfarct heart failure in type 2 diabetes. Am. J. Physiol. Heart Circ. Physiol. 2009, 297, H409-H416. [CrossRef]

116. Zhang, P.; Hou, M.; Li, Y.; Xu, X.; Barsoum, M.; Chen, Y.; Bache, R.J. NADPH oxidase contributes to coronary endothelial dysfunction in the failing heart. Am. J. Physiol. Circ. Physiol. 2009, 296, H840-H846. [CrossRef] [PubMed] 
117. Qin, F.; Simeone, M.; Patel, R. Inhibition of NADPH oxidase reduces myocardial oxidative stress and apoptosis and improves cardiac function in heart failure after myocardial infarction. Free Radic. Biol. Med. 2007, 43, 271-281. [CrossRef] [PubMed]

118. Qin, F.; Patel, R.; Yan, C.; Liu, W. NADPH oxidase is involved in angiotensin II-induced apoptosis in H9C2 cardiac muscle cells: Effects of apocynin. Free Radic. Biol. Med. 2006, 40, 236-246. [CrossRef]

119. Takayama, T.; Wada, A.; Tsutamoto, T. Contribution of vascular NAD(P)H oxidase to endothelial dysfunction in heart failure and the therapeutic effects of HMG-CoA reductase inhibitor. Circ. J. 2004, 68, 1067-1075. [CrossRef]

120. Saleem, N.; Prasad, A.; Goswami, S.K. Apocynin prevents isoproterenol-induced cardiac hypertrophy in rat. Mol. Cell. Biochem. 2018, 445, 79-88. [CrossRef] [PubMed]

121. Ishiyama, T.; Morita, Y.; Toyama, S.; Yamagami, T.; Tsukamoto, N.; Wada, N.; Ohkubo, M.; Yamamura, Y. A Clinical Study of the Effect of Coenzyme Q on Congestive Heart Failure. Jpn. Heart J. 1976, 17, 32-42. [CrossRef] [PubMed]

122. Mortensen, S.A.; Vadhanavikit, S.; Baandrup, U.; Folkers, K. Long-term coenzyme Q10 therapy: A major advance in the management of resistant myocardial failure. Drugs Exp. Clin. Res. 1985, 11, 581-593.

123. Mortensen, S.A.; Vadhanavikit, S.; Muratsu, K.; Folkers, K. Coenzyme Q10: Clinical benefits with biochemical correlates sug-gesting a scientific breakthrough in the management of chronic heart failure. Int. J. Tissue React. 1990, 12, 155-162. [PubMed]

124. Folkers, K.; Langsjoen, P.; Langsjoen, P.H. Therapy with coenzyme Q10 of patients in heart failure who are eligible or ineligible for a transplant. Biochem. Biophys. Res. Commun. 1992, 182, 247-253. [CrossRef]

125. Lei, L.; Liu, Y. Efficacy of coenzyme Q10 in patients with cardiac failure: A meta-analysis of clinical trials. BMC Cardiovasc. Disord. 2017, 17, 196. [CrossRef]

126. Hosoe, K.; Kitano, M.; Kishida, H.; Kubo, H.; Fujii, K.; Kitahara, M. Study on safety and bioavailability of ubiquinol (Kaneka $\mathrm{QH}^{\mathrm{TM}}$ ) after single and 4-week multiple oral administration to healthy volunteers. Regul. Toxicol. Pharmacol. 2007, 47, 19-28. [CrossRef] [PubMed]

127. Bhagavan, H.N.; Chopra, R.K.; Craft, N.E.; Chitchumroonchokchai, C.; Failla, M.L. Assessment of coenzyme Q10 absorption using an in vitro digestion-Caco-2 cell model. Int. J. Pharm. 2007, 333, 112-117. [CrossRef] [PubMed]

128. Langsjoen, P.H.; Langsjoen, A.M. Supplemental ubiquinol in patients with advanced congestive heart failure. Biofactors 2008, 32, 119-128. [CrossRef]

129. Lanone, S.; Bloc, S.; Foresti, R. Bilirubin decreases nos2 expression via inhibition of NAD(P)H oxidase: Implications for pro-tection against endotoxic shock in rats. FASEB J. 2005, 19, 1890-1892. [CrossRef] [PubMed]

130. Matsumoto, H.; Ishikawa, K.; Itabe, H.; Maruyama, Y. Carbon monoxide and bilirubin from heme oxygenase-1 suppresses reactive oxygen species generation and plasminogen activator inhibitor-1 induction. Mol. Cell. Biochem. 2006, 291, 21-28. [CrossRef]

131. Jiang, F.; Roberts, S.J.; Datla, S.R.; Dusting, G.J. NO Modulates NADPH Oxidase Function via Heme Oxygenase-1 in Human Endothelial Cells. Hypertension 2006, 48, 950-957. [CrossRef]

132. Datla, S.R.; Dusting, G.J.; Mori, T.A.; Taylor, C.J.; Croft, K.D.; Jiang, F. Induction of Heme Oxygenase-1 in Vivo Suppresses NADPH Oxidase-Derived Oxidative Stress. Hypertension 2007, 50, 636-642. [CrossRef] [PubMed]

133. Basuroy, S.; Bhattacharya, S.; Leffler, C.W.; Parfenova, H. Nox4 NADPH oxidase mediates oxidative stress and apoptosis caused by TNF- $\alpha$ in cerebral vascular endothelial cells. Am. J. Physiol. Physiol. 2009, 296, C422-C432. [CrossRef] [PubMed]

134. Fujii, M.; Inoguchi, T.; Sasaki, S.; Maeda, Y.; Zheng, J.; Kobayashi, K.; Takayanagi, R. Bilirubin and biliverdin protect rodents against diabetic nephropathy by downregulating NAD(P)H oxidase. Kidney Int. 2010, 78, 905-919. [CrossRef] [PubMed]

135. Ayaz, T.; Durakoglugil, M.E.; Kocaman, S.A.; Durakoğlugil, T.; Erdoğan, T.; Şahin, O.Z.; Sahin, S.B.; Satiroglu, O.; Çiçek, Y. Bilirubin Level is Associated with Left Ventricular Hypertrophy Independent of Blood Pressure in Previously Untreated Hypertensive Patients. Korean Circ. J. 2014, 44, 336-343. [CrossRef] [PubMed]

136. Zhou, T.; Chen, X.; Li, Z.; Li, L. Relationship between Serum Bilirubin and Left Ventricular Hypertrophy in Patients with Essential Hypertension. PLoS ONE 2015, 10, e0125275. [CrossRef] [PubMed]

137. Ndisang, J.F.; Jadhav, A. Upregulating the heme oxygenase system suppresses left ventricular hypertrophy in adult sponta-neously hypertensive rats for 3 months. J. Card. Fail. 2009, 15, 616-628. [CrossRef] [PubMed]

138. Hu, C.-M.; Chen, Y.-H.; Chiang, M.-T.; Chau, L.-Y. Heme Oxygenase-1 Inhibits Angiotensin II-Induced Cardiac Hypertrophy in Vitro and in Vivo. Circulation 2004, 110, 309-316. [CrossRef] [PubMed]

139. Terry, M.J.; Maines, M.D.; Lagarias, J.C. Inactivation of phytochrome- and phycobiliprotein-chromophore precursors by rat liver biliverdin reductase. J. Biol. Chem. 1993, 268, 26099-26106. [CrossRef]

140. Mccarty, M.F. Clinical Potential of Spirulina as a Source of Phycocyanobilin. J. Med. Food 2007, 10, 566-570. [CrossRef]

141. Zheng, J.; Inoguchi, T.; Sasaki, S. Phycocyanin and phycocyanobilin from Spirulina platensis protect against diabetic nephropathy by inhibiting oxidative stress. Am. J. Physiol. Regul. Integr. Comp. Physiol. 2013, 304, R110-R120. [CrossRef] [PubMed]

142. Romay, C.; Gonzalez, R.; Ledon, N.; Remirez, D.; Rimbau, V. C-Phycocyanin: A Biliprotein with Antioxidant, Anti-Inflammatory and Neuroprotective Effects. Curr. Protein Pept. Sci. 2003, 4, 207-216. [CrossRef]

143. Liu, Q.; Huang, Y.; Zhang, R.; Cai, T.; Cai, Y. Medical Application of Spirulina platensis Derived C-Phycocyanin. Evid. Based Complementary Altern. Med. 2016, 2016, 7803846. [CrossRef]

144. Penton-Rol, G.; Marin-Prida, J.; Pardo-Andreu, G. C-Phycocyanin is neuroprotective against global cerebral ische-mia/reperfusion injury in gerbils. Brain Res. Bull. 2011, 86, 42-52. [CrossRef] [PubMed] 
145. Cervantes-Llanos, M.; Lagumersindez-Denis, N.; Marín-Prida, J.; Pavón-Fuentes, N.; Falcón-Cama, V.; Piniella-Matamoros, B.; Camacho-Rodríguez, H.; Fernández-Massó, J.R.; Valenzuela-Silva, C.; Raíces-Cruz, I.; et al. Beneficial effects of oral administration of C-Phycocyanin and Phycocyanobilin in rodent models of experimental autoimmune encephalomyelitis. Life Sci. 2018, 194, 130-138. [CrossRef] [PubMed]

146. Khan, M.; Shobha, J.C.; Mohan, I.K.; Naidu, M.U.R.; Sundaram, C.; Singh, S.; Kuppusamy, P.; Kutala, V.K. Protective effect ofSpirulina against doxorubicin-induced cardiotoxicity. Phytother. Res. 2005, 19, 1030-1037. [CrossRef]

147. Khan, M.; Varadharaj, S.; Shobha, J.C.; Naidu, M.U.; Parinandi, N.L.; Kutala, V.K.; Kuppusamy, P. C-Phycocyanin Ameliorates Doxorubicin-Induced Oxidative Stress and Apoptosis in Adult Rat Cardiomyocytes. J. Cardiovasc. Pharmacol. 2006, 47, 9-20. [CrossRef] [PubMed]

148. Dickinson, D.A.; Forman, H.J. Glutathione in defense and signaling: Lessons from a small thiol. Ann. N. Y. Acad. Sci. 2002, 973, 488-504. [CrossRef]

149. Shelton, M.D.; Chock, P.B.; Mieyal, J.J. Glutaredoxin: Role in Reversible Protein S-Glutathionylation and Regulation of Redox Signal Transduction and Protein Translocation. Antioxid. Redox Signal. 2005, 7, 348-366. [CrossRef]

150. Parsons, Z.D.; Gates, K.S. Thiol-Dependent Recovery of Catalytic Activity from Oxidized Protein Tyrosine Phosphatases. Biochemistry 2013, 52, 6412-6423. [CrossRef]

151. Atkuri, K.R.; Mantovani, J.J.; Herzenberg, L.A. N-Acetylcysteine-A safe antidote for cysteine/glutathione deficiency. Curr. Opin. Pharmacol. 2007, 7, 355-359. [CrossRef] [PubMed]

152. Dodd, S.; Dean, O.; Copolov, D.L.; Malhi, G.S.; Berk, M. N-acetylcysteine for antioxidant therapy: Pharmacology and clinical utility. Expert Opin. Biol. Ther. 2008, 8, 1955-1962. [CrossRef]

153. Suh, J.H.; Shenvi, S.V.; Dixon, B.M. Decline in transcriptional activity of Nrf2 causes age-related loss of glutathione synthesis, which is reversible with lipoic acid. Proc. Natl. Acad. Sci. USA 2004, 101, 3381-3386. [CrossRef] [PubMed]

154. Rebrin, I.; Forster, M.J.; Sohal, R.S. Effects of age and caloric intake on glutathione redox state in different brain regions of C57BL/ 6 and DBA/2 mice. Brain Res. 2007, 1127, 10-18. [CrossRef] [PubMed]

155. Droge, W.; Kinscherf, R.; Hildebrandt, W.; Schmitt, T. The Deficit in Low Molecular Weight Thiols as a Target for Antiageing Therapy. Curr. Drug Targets 2006, 7, 1505-1512. [CrossRef]

156. Sekhar, R.V.; Patel, S.G.; Guthikonda, A.P.; Reid, M.; Balasubramanyam, A.; Taffet, G.E.; Jahoor, F. Deficient synthesis of glutathione underlies oxidative stress in aging and can be corrected by dietary cysteine and glycine supplementation. Am. J. Clin. Nutr. 2011, 94, 847-853. [CrossRef]

157. Foltz, W.U.; Wagner, M.; Rudakova, E.; Volk, T. N-acetylcysteine prevents electrical remodeling and attenuates cellular hypertrophy in epicardial myocytes of rats with ascending aortic stenosis. Basic Res. Cardiol. 2012, 107, 290. [CrossRef]

158. Wilder, T.; Ryba, D.M.; Wieczorek, D.F.; Wolska, B.M.; Solaro, R.J. N-acetylcysteine reverses diastolic dysfunction and hypertrophy in familial hypertrophic cardiomyopathy. Am. J. Physiol. Circ. Physiol. 2015, 309, H1720-H1730. [CrossRef]

159. Reyes, D.R.; Gomes, M.J.; Rosa, C.M.; Pagan, L.U.; Damatto, F.C.; Damatto, R.L.; DePra, I.; Campos, D.H.; Fernandez, A.A.; Martinez, P.F.; et al. N-Acetylcysteine Influence on Oxidative Stress and Cardiac Remodeling in Rats during Transition from Compensated Left Ventricular Hypertrophy to Heart Failure. Cell. Physiol. Biochem. 2017, 44, 2310-2321. [CrossRef]

160. DiNicolantonio, J.J.; Okeefe, J.H.; Mccarty, M.F. Boosting endogenous production of vasoprotective hydrogen sulfide via supplementation with taurine and N-acetylcysteine: A novel way to promote cardiovascular health. Open Heart 2017, 4, e000600. [CrossRef]

161. Yeh, C.-T.; Ching, L.-C.; Yen, G.-C. Inducing gene expression of cardiac antioxidant enzymes by dietary phenolic acids in rats. J. Nutr. Biochem. 2009, 20, 163-171. [CrossRef] [PubMed]

162. Li, J.; Ichikawa, T.; Villacorta, L.; Janicki, J.S.; Brower, G.L.; Yamamoto, M.; Cui, T. Nrf2 Protects Against Maladaptive Cardiac Responses to Hemodynamic Stress. Arterioscler. Thromb. Vasc. Biol. 2009, 29, 1843-1850. [CrossRef] [PubMed]

163. Zhou, S.; Sun, W.; Zhang, Z.; Zheng, Y. The Role of Nrf2-Mediated Pathway in Cardiac Remodeling and Heart Failure. Oxidative Med. Cell. Longev. 2014, 2014, 1-16. [CrossRef] [PubMed]

164. Strom, J.; Chen, Q.M. Loss of Nrf2 promotes rapid progression to heart failure following myocardial infarction. Toxicol. Appl. Pharmacol. 2017, 327, 52-58. [CrossRef]

165. Bubb, K.J.; Kok, C.; Tang, O. The NRF2 activator DH404 attenuates adverse ventricular remodeling post-myocardial in-farction by modifying redox signalling. Free Radic. Biol. Med. 2017, 108, 585-594. [CrossRef]

166. Fernandes, R.O.; De Castro, A.L.; Bonetto, J.H.P.; Ortiz, V.D.; Müller, D.D.; Campos-Carraro, C.; Barbosa, S.; Neves, L.T.; Xavier, L.L.; Schenkel, P.C.; et al. Sulforaphane effects on postinfarction cardiac remodeling in rats: Modulation of redox-sensitive prosurvival and proapoptotic proteins. J. Nutr. Biochem. 2016, 34, 106-117. [CrossRef]

167. Cabreiro, F.G.; Perichon, M.; Jatje, J.; Malavolta, M.; Mocchegiani, E.; Friguet, B.; Petropoulos, I. Zinc supplementation in the elderly subjects: Effect on oxidized protein degradation and repair systems in peripheral blood lymphocytes. Exp. Gerontol. 2008, 43, 483-487. [CrossRef]

168. Sullivan, V.K.; Burnett, F.R.; Cousins, R.J. Metallothionein Expression Is Increased in Monocytes and Erythrocytes of Young Men during Zinc Supplementation. J. Nutr. 1998, 128, 707-713. [CrossRef]

169. Cao, J.; Cousins, R.J. Metallothionein mRNA in Monocytes and Peripheral Blood Mononuclear Cells and in Cells from Dried Blood Spots Increases after Zinc Supplementation of Men. J. Nutr. 2000, 130, 2180-2187. [CrossRef] 
170. Aydemir, T.B.; Blanchard, R.K.; Cousins, R.J. Zinc supplementation of young men alters metallothionein, zinc transporter, and cytokine gene expression in leukocyte populations. Proc. Natl. Acad. Sci. USA 2006, 103, 1699-1704. [CrossRef]

171. Liang, Q.; Carlson, E.C.; Donthi, R.V.; Kralik, P.M.; Shen, X.; Epstein, P.N. Overexpression of metallothionein reduces diabetic cardiomyopathy. Diabetes 2002, 51, 174-181. [CrossRef] [PubMed]

172. Wang, J.; Song, Y.; Elsherif, L. Cardiac metallothionein induction plays the major role in the prevention of diabetic cardio-myopathy by zinc supplementation. Circulation 2006, 113, 544-554. [CrossRef]

173. Cai, L. Diabetic Cardiomyopathy and its Prevention by Metallothionein: Experimental Evidence, Possible Mechanisms and Clinical Implications. Curr. Med. Chem. 2007, 14, 2193-2203. [CrossRef] [PubMed]

174. Lu, Y.; Liu, Y.; Li, H.; Wang, X.; Wu, W.; Gao, L. Effect and mechanisms of zinc supplementation in protecting against diabetic cardiomyopathy in a rat model of type 2 diabetes. Bosn. J. Basic Med. Sci. 2015, 15, 14-20. [CrossRef] [PubMed]

175. Mccarty, M.F. Zinc and multi-mineral supplementation should mitigate the pathogenic impact of cadmium exposure. Med. Hypotheses 2012, 79, 642-648. [CrossRef]

176. Klaassen, C.D.; Liu, J.; Diwan, B.A. Metallothionein protection of cadmium toxicity. Toxicol. Appl. Pharmacol. 2009, 238, 215-220. [CrossRef]

177. Liu, Y.; Liu, J.; Habeebu, S.M.; Waalkes, M.P.; Klaassen, C.D. Metallothionein-I/II null mice are sensitive to chronic oral cad-mium-induced nephrotoxicity. Toxicol. Sci. 2000, 57, 167-176. [CrossRef]

178. Nakagawa, H.; Nishijo, M.; Morikawa, Y.; Miura, K.; Tawara, K.; Kuriwaki, J.-I.; Kido, T.; Ikawa, A.; Kobayashi, E.; Nogawa, K. Urinary cadmium and mortality among inhabitants of a cadmium-polluted area in Japan. Environ. Res. 2006, 100, 323-329. [CrossRef]

179. Peters, J.L.; Perlstein, T.S.; Perry, M.J.; McNeely, E.; Weuve, J. Cadmium exposure in association with history of stroke and heart failure. Environ. Res. 2010, 110, 199-206. [CrossRef]

180. Tellez-Plaza, M.; Guallar, E.; Howard, B.V.; Umans, J.G.; Francesconi, K.A.; Goessler, W.; Silbergeld, E.K.; Devereux, R.B.; Navas-Acien, A. Cadmium Exposure and Incident Cardiovascular Disease. Epidemiology 2013, 24, 421-429. [CrossRef]

181. Borné, Y.; Barregard, L.; Persson, M.; Hedblad, B.; Fagerberg, B.; Engström, G. Cadmium exposure and incidence of heart failure and atrial fibrillation: A population-based prospective cohort study. BMJ Open 2015, 5, e007366. [CrossRef] [PubMed]

182. Yang, W.; Zhang, Z.; Thijs, L.; Cauwenberghs, N.; Wei, F.; Jacobs, L.; Luttun, A.; Verhamme, P.; Kuznetsova, T.; Nawrot, T.S.; et al. Left Ventricular Structure and Function in Relation to Environmental Exposure to Lead and Cadmium. J. Am. Heart Assoc. 2017, 6, e004692. [CrossRef]

183. Hsu, C.-W.; Weng, C.-H.; Lee, C.-C.; Lin-Tan, D.-T.; Chu, P.-H.; Chen, K.-H.; Yen, T.-H.; Huang, W.-H. Urinary cadmium levels predict mortality of patients with acute heart failure. Ther. Clin. Risk Manag. 2017, 13, 379-386. [CrossRef] [PubMed]

184. Clemons, T.E.; Kurinij, N.; Sperduto, R.D. Associations of mortality with ocular disorders and an intervention of high-dose antioxidants and zinc in the Age-Related Eye Disease Study: AREDS Report No. 13. Arch. Ophthalmol. 2004, 122, 716-726. [PubMed]

185. Huang, L.; Teng, T.; Bian, B.; Yao, W.; Yu, X.; Wang, Z.; Xu, Z.; Sun, Y. Zinc Levels in Left Ventricular Hypertrophy. Biol. Trace Elem. Res. 2016, 176, 48-55. [CrossRef]

186. Stadtman, T.C. Selenium biochemistry. Mammalian selenoenzymes. Ann. N. Y. Acad. Sci. 2000, 899, 399-402. [CrossRef]

187. Rose, A.H.; Hoffmann, P.R. Selenoproteins and cardiovascular stress. Thromb. Haemost. 2015, 113, 494-504. [CrossRef] [PubMed]

188. Rayman, M.P. Selenoproteins and human health: Insights from epidemiological data. Biochim. Biophys. Acta 2009, 1790, 1533-1540. [CrossRef]

189. Tanguy, S.; Grauzam, S.; De Leiris, J.; Boucher, F. Impact of dietary selenium intake on cardiac health: Experimental approaches and human studies. Mol. Nutr. Food Res. 2012, 56, 1106-1121. [CrossRef]

190. Keshan Disease Research Group. Observations on effect of sodium selenite in prevention of Keshan disease. Chin. Med. J. 1979, 92, 471-476.

191. Alehagen, U.; Johansson, P.; Bjornstedt, M.; Rosen, A.; Dahlstrom, U. Cardiovascular mortality and N-terminal-proBNP re-duced after combined selenium and coenzyme Q10 supplementation: A 5-year prospective randomized double-blind place-bo-controlled trial among elderly Swedish citizens. Int. J. Cardiol. 2013, 167, 1860-1866. [CrossRef]

192. Alehagen, U.; Aaseth, J.; Johansson, P. Reduced Cardiovascular Mortality 10 Years after Supplementation with Selenium and Coenzyme Q10 for Four Years: Follow-Up Results of a Prospective Randomized Double-Blind Placebo-Controlled Trial in El-derly Citizens. PLoS ONE 2015, 10, e0141641. [CrossRef] [PubMed]

193. Alehagen, U.; Alexander, J.; Aaseth, J. Supplementation with Selenium and Coenzyme Q10 Reduces Cardiovascular Mortality in Elderly with Low Selenium Status. A Secondary Analysis of a Randomised Clinical Trial. PLoS ONE 2016, 11, e0157541. [CrossRef]

194. Lauver, D.A.; Lockwood, S.F.; Lucchesi, B.R. Disodium Disuccinate Astaxanthin (Cardax) Attenuates Complement Activation and Reduces Myocardial Injury following Ischemia/Reperfusion. J. Pharmacol. Exp. Ther. 2005, 314, 686-692. [CrossRef] [PubMed]

195. Qiu, X.; Fu, K.; Zhao, X.; Zhang, Y.; Yuan, Y.; Zhang, S.; Gu, X.; Guo, H. Protective effects of astaxanthin against ischemia/reperfusion induced renal injury in mice. J. Transl. Med. 2015, 13, 28-29. [CrossRef] [PubMed]

196. Xue, Y.; Qu, Z.; Fu, J.; Zhen, J.; Wang, W.; Cai, Y.; Wang, W. The protective effect of astaxanthin on learning and memory deficits and oxidative stress in a mouse model of repeated cerebral ischemia/reperfusion. Brain Res. Bull. 2017, 131, 221-228. [CrossRef] 
197. Alam, M.N.; Hossain, M.M.; Rahman, M.M. Astaxanthin Prevented Oxidative Stress in Heart and Kidneys of Isopro-terenolAdministered Aged Rats. J. Diet. Suppl. 2018, 15, 42-54. [CrossRef]

198. García, J.A.; Volt, H.; Venegas, C.; Doerrier, C.; Escames, G.; López, L.C.; Acuña-Castroviejo, D. Disruption of the NF-kB/NLRP3 connection by melatonin requires retinoid-related orphan receptor- $\alpha$ and blocks the septic response in mice. FASEB J. 2015, 29, 3863-3875. [CrossRef]

199. Early, J.O.; Menon, D.; Wyse, C.A. Circadian clock protein BMAL1 regulates IL-1 $\hat{\mathrm{I}}^{2}$ in macrophages via NRF2. Proc. Natl. Acad. Sci. USA 2018, 115, E8460-E8468. [CrossRef]

200. Zhou, B.; Zhang, Y.; Zhang, F.; Xia, Y.; Liu, J.; Huang, R.; Wang, Y.; Hu, Y.; Wu, J.; Dai, C.; et al. CLOCK/BMAL1 regulates circadian change of mouse hepatic insulin sensitivity by SIRT1. Hepatology 2014, 59, 2196-2206. [CrossRef]

201. Yu, L.; Sun, Y.; Cheng, L.; Jin, Z.; Yang, Y.; Zhai, M.; Pei, H.; Wang, X.; Zhang, H.; Meng, Q.; et al. Melatonin receptor-mediated protection against myocardial ischemia/reperfusion injury: Role of SIRT1. J. Pineal Res. 2014, 57, 228-238. [CrossRef]

202. Huang, X.Z.; Wen, D.; Zhang, M. Sirt1 activation ameliorates renal fibrosis by inhibiting the TGF- ${ }^{2} /$ Smad3 pathway. J. Cell. Biochem. 2014, 115, 996-1005. [CrossRef]

203. Zeng, Z.; Cheng, S.; Chen, H.; Li, Q.; Hu, Y.; Wang, Q.; Zhu, X.; Wang, J. Activation and overexpression of Sirt1 attenuates lung fibrosis via P300. Biochem. Biophys. Res. Commun. 2017, 486, 1021-1026. [CrossRef] [PubMed]

204. Kuno, A.; Hori, Y.S.; Hosoda, R. Resveratrol improves cardiomyopathy in dystrophin-deficient mice through SIRT1 pro-teinmediated modulation of p300 protein. J. Biol. Chem. 2013, 288, 5963-5972. [CrossRef]

205. Li, Z.; Wang, F.; Zha, S.; Cao, Q.; Sheng, J.; Chen, S. SIRT1 inhibits TGF- $\hat{I}^{2}$-induced endothelial-mesenchymal transition in human endothelial cells with Smad4 deacetylation. J. Cell. Physiol. 2018, 233, 9007-9014. [CrossRef]

206. Bugyei-Twum, A.; Ford, C.; Civitarese, R. Sirtuin 1 activation attenuates cardiac fibrosis in a rodent pressure overload model by modifying Smad2/3 transactivation. Cardiovasc. Res. 2018, 114, 1629-1641. [CrossRef]

207. Simko, F.; Paulis, L. Antifibrotic effect of melatonin-Perspective protection in hypertensive heart disease. Int. J. Cardiol. 2013, 168, 2876-2877. [CrossRef] [PubMed]

208. Paulis, L.; Pechanova, O.; Zicha, J.; Krajcirovicova, K.; Barta, A.; Pelouch, V.; Adamcova, M.; Simko, F. Melatonin prevents fibrosis but not hypertrophy development in the left ventricle of NG-nitro-L-arginine-methyl ester hypertensive rats. J. Hypertens. 2009, 27, S11-S16. [CrossRef]

209. Hu, W.; Ma, Z.; Jiang, S.; Fan, C.; Deng, C.; Yan, X.; Di, S.; Lv, J.; Reiter, R.J.; Yang, Y. Melatonin: The dawning of a treatment for fibrosis? J. Pineal Res. 2015, 60, 121-131. [CrossRef]

210. Wu, Y.; Si, F.; Luo, L.; Jing, F.; Jiang, K.; Zhou, J.; Yi, Q. The effect of melatonin on cardio fibrosis in juvenile rats with pressure overload and deregulation of HDACs. Korean J. Physiol. Pharmacol. 2018, 22, 607-616. [CrossRef] [PubMed]

211. Che, H.; Wang, Y.; Li, H. Melatonin alleviates cardiac fibrosis via inhibiting lncRNA MALAT1/miR-141-mediated NLRP3 inflammasome and TGF- $\hat{I}^{2} 1$ Smads signaling in diabetic cardiomyopathy. FASEB J. 2020, 34, 5282-5298. [CrossRef] [PubMed]

212. Castillero, E.; Akashi, H.; Pendrak, K.; Yerebakan, H.; Najjar, M.; Wang, C.; Naka, Y.; Mancini, N.M.; Sweeney, H.L.; D'armiento, J.; et al. Attenuation of the unfolded protein response and endoplasmic reticulum stress after mechanical unloading in dilated cardiomyopathy. Am. J. Physiol. Circ. Physiol. 2015, 309, H459-H470. [CrossRef] [PubMed]

213. Sano, R.; Reed, J.C. ER stress-induced cell death mechanisms. Biochim. Biophys. Acta 2013, 1833, 3460-3470. [CrossRef]

214. Groenendyk, J.; Lee, D.; Jung, J.; Dyck, J.R.B.; Lopaschuk, G.D.; Agellon, L.B.; Michalak, M. Inhibition of the Unfolded Protein Response Mechanism Prevents Cardiac Fibrosis. PLoS ONE 2016, 11, e0159682. [CrossRef]

215. Rani, S.; Sreenivasaiah, P.K.; Kim, J.O.; Lee, M.Y.; Kang, W.S.; Kim, Y.S.; Ahn, Y.; Park, W.J.; Cho, C.; Kim, D.H. Tauroursodeoxycholic acid (TUDCA) attenuates pressure overload-induced cardiac remodeling by reducing endoplasmic reticulum stress. PLoS ONE 2017, 12, e0176071. [CrossRef]

216. Turdi, S.; Hu, N.; Ren, J. Tauroursodeoxycholic acid mitigates high fat diet-induced cardiomyocyte contractile and intracellular $\mathrm{Ca}^{2+}$ anomalies. PLoS ONE 2013, 8, e63615. [CrossRef]

217. Ceylan-Isik, A.F.; Sreejayan, N.; Ren, J. Endoplasmic reticulum chaperon tauroursodeoxycholic acid alleviates obesity-induced myocardial contractile dysfunction. J. Mol. Cell. Cardiol. 2011, 50, 107-116. [CrossRef] [PubMed]

218. Park, C.S.; Cha, H.; Kwon, E.J.; Sreenivasaiah, P.K.; Kim, D.H. The chemical chaperone 4-phenylbutyric acid attenuates pressureoverload cardiac hypertrophy by alleviating endoplasmic reticulum stress. Biochem. Biophys. Res. Commun. 2012, 421, 578-584. [CrossRef] [PubMed]

219. Zhang, Y.; Li, X.; Zou, D.; Liu, W.; Yang, J.; Zhu, N.; Huo, L.; Wang, M.; Hong, J.; Wu, P.; et al. Treatment of Type 2 Diabetes and Dyslipidemia with the Natural Plant Alkaloid Berberine. J. Clin. Endocrinol. Metab. 2008, 93, 2559-2565. [CrossRef]

220. Lan, J.; Zhao, Y.; Dong, F.; Yan, Z.; Zheng, W.; Fan, J.; Sun, G. Meta-analysis of the effect and safety of berberine in the treatment of type 2 diabetes mellitus, hyperlipemia and hypertension. J. Ethnopharmacol. 2015, 161, 69-81. [CrossRef]

221. Chang, W.; Chen, L.; Hatch, G.M. Berberine as a therapy for type 2 diabetes and its complications: From mechanism of action to clinical studies. Biochem. Cell Biol. 2015, 93, 479-486. [CrossRef]

222. Lee, Y.S.; Kim, W.S.; Kim, K.H.; Yoon, M.J.; Cho, H.J.; Shen, Y.; Ye, J.-M.; Lee, C.H.; Oh, W.K.; Kim, C.T.; et al. Berberine, a Natural Plant Product, Activates AMP-Activated Protein Kinase with Beneficial Metabolic Effects in Diabetic and Insulin-Resistant States. Diabetes 2006, 55, 2256-2264. [CrossRef] 
223. Turner, N.; Li, J.-Y.; Gosby, A.; To, S.W.; Cheng, Z.; Miyoshi, H.; Taketo, M.M.; Cooney, G.J.; Kraegen, E.W.; James, D.E.; et al. Berberine and Its More Biologically Available Derivative, Dihydroberberine, Inhibit Mitochondrial Respiratory Complex I: A Mechanism for the Action of Berberine to Activate AMP-Activated Protein Kinase and Improve Insulin Action. Diabetes 2008, 57, 1414-1418. [CrossRef]

224. Marin-Neto, J.A.; Maciel, B.C.; Secches, A.L.; Júnior, L.G. Cardiovascular effects of berberine in patients with severe congestive heart failure. Clin. Cardiol. 1988, 11, 253-260. [CrossRef] [PubMed]

225. Zeng, X.; Zeng, X. Relationship between the clinical effects of berberine on severe congestive heart failure and its concentration in plasma studied by HPLC. Biomed. Chromatogr. 1999, 13, 442-444. [CrossRef]

226. Hong, Y.; Hui, S.-C.; Chan, T.-Y.; Hou, J.-Y. Effect of Berberine on Regression of Pressure-Overload Induced Cardiac Hypertrophy in Rats. Am. J. Chin. Med. 2002, 30, 589-599. [CrossRef] [PubMed]

227. Zeng, X.H.; Zeng, X.J.; Li, Y.Y. Efficacy and safety of berberine for congestive heart failure secondary to ischemic or idiopathic dilated cardiomyopathy. Am. J. Cardiol. 2003, 92, 173-176. [CrossRef]

228. Dziubak, A.; Wójcicka, G. The pathophysiological basis of the protective effects of metformin in heart failure. Postępy Higieny $i$ Medycyny Doświadczalnej 2017, 71, 773-787. [CrossRef] [PubMed]

229. Feng, Y.; Zhang, Y.; Xiao, H. AMPK and cardiac remodelling. Sci. China Life Sci. 2018, 61, 14-23. [CrossRef] [PubMed]

230. Terai, K.; Hiramoto, Y.; Masaki, M.; Sugiyama, S.; Kuroda, T.; Hori, M.; Kawase, I.; Hirota, H. AMP-Activated Protein Kinase Protects Cardiomyocytes against Hypoxic Injury through Attenuation of Endoplasmic Reticulum Stress. Mol. Cell. Biol. 2005, 25, 9554-9575. [CrossRef] [PubMed]

231. Dong, Y.; Zhang, M.; Liang, B.; Xie, Z.; Zhao, Z.; Asfa, S.; Choi, H.C.; Zou, M.-H. Reduction of AMP-Activated Protein Kinase $\alpha 2$ Increases Endoplasmic Reticulum Stress and Atherosclerosis in Vivo. Circulation 2010, 121, 792-803. [CrossRef]

232. Yeh, C.H.; Chen, T.P.; Wang, Y.C.; Lin, Y.M.; Fang, S.W. AMP-activated protein kinase activation during cardioplegia-induced hy-poxia/reoxygenation injury attenuates cardiomyocytic apoptosis via reduction of endoplasmic reticulum stress. Mediat. Inflamm. 2010, 2010, 130636. [CrossRef]

233. Zhuo, X.Z.; Wu, Y.; Ni, Y.J. Isoproterenol instigates cardiomyocyte apoptosis and heart failure via AMPK inactiva-tion-mediated endoplasmic reticulum stress. Apoptosis 2013, 18, 800-810. [CrossRef]

234. Kim, H.; Moon, S.Y.; Kim, J.-S.; Baek, C.H.; Kim, M.; Min, J.Y.; Lee, S.K. Activation of AMP-activated protein kinase inhibits ER stress and renal fibrosis. Am. J. Physiol. Physiol. 2015, 308, F226-F236. [CrossRef] [PubMed]

235. Hardie, D.G.; Lin, S.-C. AMP-activated protein kinase-Not just an energy sensor. F1000Research 2017, 6, 1724. [CrossRef]

236. Browne, G.J.; Finn, S.G.; Proud, C.G. Stimulation of the AMP-activated protein kinase leads to activation of eukaryotic elon-gation factor 2 kinase and to its phosphorylation at a novel site, serine 398. J. Biol. Chem. 2004, 279, 12220-12231. [CrossRef]

237. Johanns, M.; dit Ruys, S.P.; Houddane, A. Direct and indirect activation of eukaryotic elongation factor 2 kinase by AMP-activated protein kinase. Cell. Signal. 2017, 36, 212-221. [CrossRef] [PubMed]

238. Chen, Z.-P.; Mitchelhill, K.I.; Michell, B.J.; Stapleton, D.; Rodriguez-Crespo, I.; Witters, L.A.; Power, D.A.; De Montellano, P.R.O.; Kemp, B.E. AMP-activated protein kinase phosphorylation of endothelial NO synthase. FEBS Lett. 1999, 443, 285-289. [CrossRef]

239. Morrow, V.A.; Foufelle, F.; Connell, J.M.C.; Petrie, J.R.; Gould, G.W.; Salt, I.P. Direct Activation of AMP-activated Protein Kinase Stimulates Nitric-oxide Synthesis in Human Aortic Endothelial Cells. J. Biol. Chem. 2003, 278, 31629-31639. [CrossRef] [PubMed]

240. McCarty, M.F. Asymmetric Dimethylarginine Is a Well Established Mediating Risk Factor for Cardiovascular Morbidity and Mortality-Should Patients with Elevated Levels Be Supplemented with Citrulline? Healthcare 2016, 4, 40. [CrossRef]

241. Gao, L.; Siu, K.L.; Chalupsky, K. Role of uncoupled endothelial nitric oxide synthase in abdominal aortic aneurysm formation: Treatment with folic acid. Hypertension 2012, 59, 158-166. [CrossRef] [PubMed]

242. Siu, K.L.; Miao, X.N.; Cai, H. Recoupling of eNOS with Folic Acid Prevents Abdominal Aortic Aneurysm Formation in Angiotensin II-Infused Apolipoprotein E Null Mice. PLoS ONE 2014, 9, e88899. [CrossRef]

243. Chalupsky, K.; Kračun, D.; Kanchev, I.; Bertram, K.; Görlach, A. Folic Acid Promotes Recycling of Tetrahydrobiopterin and Protects against Hypoxia-Induced Pulmonary Hypertension by Recoupling Endothelial Nitric Oxide Synthase. Antioxid. Redox Signal. 2015, 23, 1076-1091. [CrossRef]

244. Rezk, B.M.; Haenen, G.R.; Van Der Vijgh, W.J.; Bast, A. Tetrahydrofolate and 5-methyltetrahydrofolate are folates with high antioxidant activity. Identification of the antioxidant pharmacophore. FEBS Lett. 2003, 555, 601-605. [CrossRef]

245. Antoniades, C.; Shirodaria, C.; Warrick, N. 5-methyltetrahydrofolate rapidly improves endothelial function and decreases superoxide production in human vessels: Effects on vascular tetrahydrobiopterin availability and endothelial nitric oxide synthase coupling. Circulation 2006, 114, 1193-1201. [CrossRef] [PubMed]

246. McCarty, M.F.; Barroso-Aranda, J.; Contreras, F. High-dose folate and dietary purines promote scavenging of peroxyni-tritederived radicals-Clinical potential in inflammatory disorders. Med. Hypotheses 2009, 73, 824-834. [CrossRef] [PubMed]

247. Mccarty, M.F. Oster rediscovered-Mega-dose folate for symptomatic atherosclerosis. Med. Hypotheses 2007, 69, 325-332. [CrossRef]

248. Moens, A.L.; Claeys, M.J.; Wuyts, F.L.; Goovaerts, I.; Van Hertbruggen, E.; Wendelen, L.C.; Van Hoof, V.O.; Vrints, C.J. Effect of Folic Acid on Endothelial Function Following Acute Myocardial Infarction. Am. J. Cardiol. 2007, 99, 476-481. [CrossRef]

249. Moens, A.L.; Vrints, C.J.; Claeys, M.J.; Timmermans, J.-P.; Champion, H.C.; Kass, D.A. Mechanisms and potential therapeutic targets for folic acid in cardiovascular disease. Am. J. Physiol. Circ. Physiol. 2008, 294, H1971-H1977. [CrossRef] [PubMed] 
250. Ionova, I.A.; Vásquez-Vivar, J.; Whitsett, J.; Herrnreiter, A.; Medhora, M.; Cooley, B.C.; Pieper, G.M. Deficient BH4 production via de novo and salvage pathways regulates NO responses to cytokines in adult cardiac myocytes. Am. J. Physiol. Circ. Physiol. 2008, 295, H2178-H2187. [CrossRef]

251. Tawakol, A.; Migrino, R.Q.; Aziz, K.S.; Waitkowska, J.; Holmvang, G.; Alpert, N.M.; Muller, J.E.; Fischman, A.J.; Gewirtz, H. High-dose folic acid acutely improves coronary vasodilator function in patients with coronary artery disease. J. Am. Coll. Cardiol. 2005, 45, 1580-1584. [CrossRef] [PubMed]

252. Piquereau, J.; Moulin, M.; Zurlo, G.; Mateo, P.; Gressette, M.; Paul, J.-L.; Lemaire, C.; Ventura-Clapier, R.; Veksler, V.; Garnier, A. Cobalamin and folate protect mitochondrial and contractile functions in a murine model of cardiac pressure overload. J. Mol. Cell. Cardiol. 2017, 102, 34-44. [CrossRef] [PubMed]

253. Octavia, Y.; Kararigas, G.; De Boer, M.; Chrifi, I.; Kietadisorn, R.; Swinnen, M.; Duimel, H.; Verheyen, F.K.; Brandt, M.M.; Fliegner, D.; et al. Folic acid reduces doxorubicin-induced cardiomyopathy by modulating endothelial nitric oxide synthase. J. Cell. Mol. Med. 2017, 21, 3277-3287. [CrossRef]

254. Moens, A.L.; Champion, H.C.; Claeys, M.J. High-dose folic acid pretreatment blunts cardiac dysfunction during ischemia coupled to maintenance of high-energy phosphates and reduces postreperfusion injury. Circulation 2008, 117, 1810-1819. [CrossRef]

255. Usui, M.; Matsuoka, H.; Miyazaki, H.; Ueda, S.; Okuda, S.; Imaizumi, T. Increased endogenous nitric oxide synthase inhibitor in patients with congestive heart failure. Life Sci. 1998, 62, 2425-2430. [CrossRef]

256. Saitoh, M.; Osanai, T.; Kamada, T.; Matsunaga, T.; Ishizaka, H.; Hanada, H.; Okumura, K. High plasma level of asymmetric dimethylarginine in patients with acutely exacerbated congestive heart failure: Role in reduction of plasma nitric oxide level. Heart Vessels 2003, 18, 177-182. [CrossRef]

257. Kielstein, J.T.; Bode-Boger, S.M.; Klein, G.; Graf, S.; Haller, H.; Fliser, D. Endogenous nitric oxide synthase inhibitors and renal perfusion in patients with heart failure. Eur. J. Clin. Investig. 2003, 33, 370-375. [CrossRef]

258. Dückelmann, C.; Mittermayer, F.; Haider, D.G.; Altenberger, J.; Eichinger, J.; Wolzt, M. Asymmetric Dimethylarginine Enhances Cardiovascular Risk Prediction in Patients with Chronic Heart Failure. Arterioscler. Thromb. Vasc. Biol. 2007, 27, $2037-2042$. [CrossRef]

259. Zairis, M.N.; Patsourakos, N.G.; Tsiaousis, G.Z.; Georgilas, A.T.; Melidonis, A.; Makrygiannis, S.S.; Velissaris, D.; Batika, P.C.; Argyrakis, K.S.; Tzerefos, S.P.; et al. Plasma asymmetric dimethylarginine and mortality in patients with acute decompensation of chronic heart failure. Heart 2012, 98, 860-864. [CrossRef] [PubMed]

260. Hsu, C.-P.; Lin, S.-J.; Chung, M.-Y.; Lu, T.-M. Asymmetric dimethylarginine predicts clinical outcomes in ischemic chronic heart failure. Atherosclerosis 2012, 225, 504-510. [CrossRef]

261. Sverdlov, A.; Ngo, D.; Nightingale, A.; Rajendran, S.; Mishra, K.; Heresztyn, T.; Ritchie, R.; Marwick, T.; Frenneaux, M.; Horowitz, J. The endogenous NOS inhibitor asymmetric dimethylarginine (ADMA) predicts LV mass independent of afterload. Nitric Oxide 2011, 25, 41-46. [CrossRef] [PubMed]

262. Bai, Y.; Hui, R. Dimethylarginine dimethylaminohydrolase (DDAH)—A critical regulator of hypertensive left ventricular hy-pertrophy? Med. Hypotheses 2008, 70, 962-966. [CrossRef]

263. Shi, B.; Ni, Z.; Zhou, W.; Yu, Z.; Gu, L.; Mou, S.; Fang, W.; Wang, Q.; Cao, L.; Yan, Y.; et al. Circulating levels of asymmetric dimethylarginine are an independent risk factor for left ventricular hypertrophy and predict cardiovascular events in pre-dialysis patients with chronic kidney disease. Eur. J. Intern. Med. 2010, 21, 444-448. [CrossRef] [PubMed]

264. Ebinc, F.A.; Erten, Y.; Ebinç, H.; Pasaoglu, H.; Demirtas, C.; Tacoy, G.; Mutluay, R.; Koc, E.; Derici, U.; Reis, K.A.; et al. The Relationship among Asymmetric Dimethylarginine (ADMA) Levels, Residual Renal Function, and Left Ventricular Hypertrophy in Continuous Ambulatory Peritoneal Dialysis Patients. Ren. Fail. 2008, 30, 401-406. [CrossRef] [PubMed]

265. Antoniades, C.; Shirodaria, C.; Leeson, P.; Antonopoulos, A.; Warrick, N.; Van-Assche, T.; Cunnington, C.; Tousoulis, D.; Pillai, R.; Ratnatunga, C.; et al. Association of plasma asymmetrical dimethylarginine (ADMA) with elevated vascular superoxide production and endothelial nitric oxide synthase uncoupling: Implications for endothelial function in human atherosclerosis. Eur. Heart J. 2009, 30, 1142-1150. [CrossRef]

266. Collins, J.K.; Wu, G.; Perkins-Veazie, P.; Spears, K.; Claypool, P.L.; Baker, R.A.; Clevidence, B.A. Watermelon consumption increases plasma arginine concentrations in adults. Nutrition 2007, 23, 261-266. [CrossRef]

267. Waugh, W.H.; Daeschner, C.W.; Files, B.A.; McConnell, M.E.; Strandjord, S.E. Oral citrulline as arginine precursor may be beneficial in sickle cell disease: Early phase two results. J. Natl. Med. Assoc. 2001, 93, 363-371.

268. Schwedhelm, E.; Maas, R.; Freese, R.; Jung, D.; Lukacs, Z.; Jambrecina, A.; Spickler, W.; Schulze, F.; Böger, R.H. Pharmacokinetic and pharmacodynamic properties of oral L-citrulline and L-arginine: Impact on nitric oxide metabolism. Br. J. Clin. Pharmacol. 2008, 65, 51-59. [CrossRef]

269. Romero, M.J.; Platt, D.H.; Caldwell, R.W. Therapeutic Use of Citrulline in Cardiovascular Disease. Cardiovasc. Drug Rev. 2006, 24, 275-290. [CrossRef]

270. Balderas-Munoz, K.; Castillo-Martínez, L.; Orea-Tejeda, A.; Infante-Vázquez, O.; Utrera-Lagunas, M.; Martínez-Memije, R.; Keirns-Davis, C.; Becerra-Luna, B.; Sánchez-Vidal, G. Improvement of ventricular function in systolic heart failure patients with oral L-citrulline supplementation. Cardiol. J. 2012, 19, 612-617. [CrossRef]

271. Simon, T.; Mary-Krause, M.; Funck-Brentano, C.; Jaillon, P. Sex differences in the prognosis of congestive heart failure: Results from the Cardiac Insufficiency Bisoprolol Study (CIBIS II). Circulation 2001, 103, 375-380. [CrossRef] [PubMed] 
272. Patrizio, M.; Marano, G. Gender differences in cardiac hypertrophic remodeling. Annali dell'Istituto Superiore di Sanità 2016, 52, 223-229. [PubMed]

273. Scott, N.S. Understanding Hormones, Menopause, and Heart Failure: Still a Work in Progress. J. Am. Coll. Cardiol. 2017, 69, 2527-2529. [CrossRef]

274. Lim, W.K.; Wren, B.; Jepson, N.; Roy, S.; Caplan, G. Effect of hormone replacement therapy on left ventricular hypertrophy. Am. J. Cardiol. 1999, 83, 1132-1134. [CrossRef]

275. Modena, M.G.; Molinari, R.; Muia, N.; Castelli, A., Jr.; Pala, F.; Rossi, R. Double-blind randomized placebo-controlled study of transdermal estrogen replacement therapy on hypertensive postmenopausal women. Am. J. Hypertens. 1999, 12, 1000-1008. [CrossRef]

276. Light, K.C.; Hinderliter, A.L.; West, S.G.; Grewen, K.M.; Steege, J.F.; Sherwood, A.; Girdler, S.S. Hormone replacement improves hemodynamic profile and left ventricular geometry in hypertensive and normotensive postmenopausal women. J. Hypertens. 2001, 19, 269-278. [CrossRef] [PubMed]

277. Wu, C.H.; Liu, J.Y.; Wu, J.P. 17beta-estradiol reduces cardiac hypertrophy mediated through the up-regulation of PI3K/Akt and the suppression of calcineurin/NF-AT3 signaling pathways in rats. Life Sci. 2005, 78, 347-356. [CrossRef]

278. Pedram, A.; Razandi, M.; Narayanan, R.; Dalton, J.T.; McKinsey, T.A.; Levin, E.R. Estrogen regulates histone deacetylases to prevent cardiac hypertrophy. Mol. Biol. Cell 2013, 24, 3805-3818. [CrossRef]

279. Cui, Y.H.; Tan, Z.; Fu, X.D.; Xiang, Q.L.; Xu, J.W.; Wang, T.H. 17 beta-estradiol attenuates pressure overload-induced myocardial hy-pertrophy through regulating caveolin-3 protein in ovariectomized female rats. Mol. Biol. Rep. 2011, 38, 4885-4892. [CrossRef]

280. Gardner, J.D.; Murray, D.B.; Voloshenyuk, T.G.; Brower, G.L.; Bradley, J.M.; Janicki, J.S. Estrogen attenuates chronic volume overload induced structural and functional remodeling in male rat hearts. Am. J. Physiol. Circ. Physiol. 2010, 298, H497-H504. [CrossRef]

281. Grohé, C.; Kahlert, S.; Löbbert, K.; Stimpel, M.; Karas, R.H.; Vetter, H.; Neyses, L. Cardiac myocytes and fibroblasts contain functional estrogen receptors 1. FEBS Lett. 1997, 416, 107-112. [CrossRef]

282. Lizotte, E.; Grandy, S.A.; Tremblay, A.; Allen, B.G.; Fiset, C. Expression, Distribution and Regulation of Sex Steroid Hormone Receptors in Mouse Heart. Cell. Physiol. Biochem. 2009, 23, 075-086. [CrossRef]

283. Skavdahl, M.; Steenbergen, C.; Clark, J. Estrogen receptor-beta mediates male-female differences in the development of pressure overload hypertrophy. Am. J. Physiol. Heart Circ. Physiol. 2005, 288, H469-H476. [CrossRef]

284. Fliegner, D.; Schubert, C.; Penkalla, A. Female sex and estrogen receptor-beta attenuate cardiac remodeling and apoptosis in pressure overload. Am. J. Physiol. Regul. Integr. Comp. Physiol. 2010, 298, R1597-R1606. [CrossRef] [PubMed]

285. Wang, M.; Wang, Y.; Weil, B. Estrogen receptor beta mediates increased activation of PI3K/Akt signaling and improved myocardial function in female hearts following acute ischemia. Am. J. Physiol. Regul. Integr. Comp. Physiol. 2009, 296, R972-R978. [CrossRef]

286. Hoa, N.; Ge, L.; Korach, K.S.; Levin, E.R. Estrogen receptor beta maintains expression of KLF15 to prevent cardiac myocyte hypertrophy in female rodents. Mol. Cell. Endocrinol. 2018, 470, 240-250. [CrossRef]

287. Pedram, A.; Razandi, M.; O'Mahony, F.; Lubahn, D.; Levin, E.R. Estrogen receptor-beta prevents cardiac fibrosis. Mol. Endocrinol. 2010, 24, 2152-2165. [CrossRef] [PubMed]

288. Schuster, I.; Mahmoodzadeh, S.; Dworatzek, E. Cardiomyocyte-specific overexpression of oestrogen receptor beta improves survival and cardiac function after myocardial infarction in female and male mice. Clin. Sci. 2016, 130, 365-376. [CrossRef]

289. Nuedling, S.; Kahlert, S.; Loebbert, K. 17 Beta-estradiol stimulates expression of endothelial and inducible NO synthase in rat myocardium in-vitro and in-vivo. Cardiovasc. Res. 1999, 43, 666-674. [CrossRef]

290. Nuedling, S.; Karas, R.H.; Mendelsohn, M.E. Activation of estrogen receptor beta is a prerequisite for estrogen-dependent upregulation of nitric oxide synthases in neonatal rat cardiac myocytes. FEBS Lett. 2001, 502, 103-108. [CrossRef]

291. Kuiper, G.G.; Carlsson, B.; Grandien, K. Comparison of the ligand binding specificity and transcript tissue distribution of estrogen receptors alpha and beta. Endocrinology 1997, 138, 863-870. [CrossRef] [PubMed]

292. Kuiper, G.G.; Lemmen, J.G.; Carlsson, B. Interaction of estrogenic chemicals and phytoestrogens with estrogen receptor beta. Endocrinology 1998, 139, 4252-4263. [CrossRef]

293. Mccarty, M.F. Isoflavones made simple-Genistein's agonist activity for the beta-type estrogen receptor mediates their health benefits. Med. Hypotheses 2006, 66, 1093-1114. [CrossRef]

294. Jackson, R.L.; Greiwe, J.S.; Schwen, R.J. Emerging evidence of the health benefits of S-equol, an estrogen receptor $\beta$ agonist. Nutr. Rev. 2011, 69, 432-448. [CrossRef] [PubMed]

295. Li, J.; Xie, Z.-Z.; Tang, Y.-B. Genistein Prevents Myocardial Hypertrophy in 2-Kidney 1-Clip Renal Hypertensive Rats by Restoring eNOS Pathway. Pharmacology 2010, 86, 240-248. [CrossRef]

296. Matori, H.; Umar, S.; Nadadur, R.D.; Sharma, S.; Partow-Navid, R.; Afkhami, M.; Amjedi, M.; Eghbali, M. Genistein, a Soy Phytoestrogen, Reverses Severe Pulmonary Hypertension and Prevents Right Heart Failure in Rats. Hypertension 2012, 60, 425-430. [CrossRef]

297. Maulik, S.K.; Prabhakar, P.; Dinda, A.K.; Seth, S. Genistein prevents isoproterenol-induced cardiac hypertrophy in rats. Can. J. Physiol. Pharmacol. 2012, 90, 1117-1125. [CrossRef]

298. Qin, W.; Du, N.; Zhang, L.; Wu, X.; Hu, Y.; Li, X.; Shen, N.; Li, Y.; Yang, B.; Xu, C.; et al. Genistein alleviates pressure overload-induced cardiac dysfunction and interstitial fibrosis in mice. Br. J. Pharmacol. 2015, 172, 5559-5572. [CrossRef] 
299. Meng, Y.; Zhang, Y.; Ma, Z.; Zhou, H.; Ni, J.; Liao, H.; Tang, Q. Genistein attenuates pathological cardiac hypertrophy in vivo and in vitro. Herz 2017, 44, 247-256. [CrossRef] [PubMed]

300. Tang, Y.-B.; Wang, Q.-L.; Zhu, B.-Y.; Huang, H.-L.; Liao, D.-F. Phytoestrogen genistein supplementation increases eNOS and decreases caveolin-1 expression in ovariectomized rat hearts. Sheng Li Xue Bao 2005, 57, 373-378.

301. Fisher, N.D.; Hughes, M.; Gerhard-Herman, M.; Hollenberg, N.K. Flavanol-rich cocoa induces nitric-oxide-dependent vasodilation in healthy humans. J. Hypertens. 2003, 21, 2281-2286. [CrossRef]

302. Hollenberg, K. Vascular action of cocoa flavanols in humans: The roots of the story. J. Cardiovasc. Pharmacol. 2006, 47 (Suppl. 2), S99-S102. [CrossRef]

303. Ramirez-Sanchez, I.; Maya, L.; Ceballos, G.; Villarreal, F. (-)-Epicatechin Activation of Endothelial Cell Endothelial Nitric Oxide Synthase, Nitric Oxide, and Related Signaling Pathways. Hypertension 2010, 55, 1398-1405. [CrossRef]

304. Ramírez-Sánchez, I.; Maya, L.; Ceballos, G.; Villarreal, F. (-)-Epicatechin induces calcium and translocation independent eNOS activation in arterial endothelial cells. Am. J. Physiol. Physiol. 2011, 300, C880-C887. [CrossRef] [PubMed]

305. De, P.R.; Sotto, I.; Wood, E.G. Cocoa flavanols reduce N-terminal pro-B-type natriuretic peptide in patients with chronic heart failure. ESC Heart Fail. 2016, 3, 97-106.

306. Caton, P.W.; Pothecary, M.R.; Lees, D.M.; Khan, N.Q.; Wood, E.G.; Shoji, T.; Kanda, T.; Rull, G.; Corder, R. Regulation of Vascular Endothelial Function by Procyanidin-Rich Foods and Beverages. J. Agric. Food Chem. 2010, 58, 4008-4013. [CrossRef]

307. Brixius, K.; Willms, S.; Napp, A. Crataegus special extract WS 1442 induces an endothelium-dependent, NO-mediated vasorelaxation via eNOS-phosphorylation at serine 1177. Cardiovasc. Drugs Ther. 2006, 20, 177-184. [CrossRef] [PubMed]

308. Anselm, E.; Socorro, V.F.M.; Dal-Ros, S.; Schott, C.; Bronner, C.; Schini-Kerth, V.B. Crataegus Special Extract WS 1442 Causes Endothelium-dependent Relaxation via a Redox-sensitive Src- and Akt-dependent Activation of Endothelial NO Synthase but Not via Activation of Estrogen Receptors. J. Cardiovasc. Pharmacol. 2009, 53, 253-260. [CrossRef]

309. Pittler, M.H.; Guo, R.; Ernst, E. Hawthorn extract for treating chronic heart failure. Cochrane Database Syst. Rev. 2008, 1, CD005312.

310. Lundberg, J.O.; Weitzberg, E. NO Generation from Nitrite and Its Role in Vascular Control. Arterioscler. Thromb. Vasc. Biol. 2005, 25, 915-922. [CrossRef]

311. Lundberg, J.O.; Gladwin, M.T.; Ahluwalia, A.; Benjamin, N.; Bryan, N.S.; Butler, A.R.; Cabrales, P.; Fago, A.; Feelisch, M.; Ford, P.C.; et al. Nitrate and nitrite in biology, nutrition and therapeutics. Nat. Chem. Biol. 2009, 5, 865-869. [CrossRef]

312. Kapil, V.; Milsom, A.B.; Okorie, M. Inorganic nitrate supplementation lowers blood pressure in humans: Role for nitrite-derived NO. Hypertension 2010, 56, 274-281. [CrossRef] [PubMed]

313. Webb, A.J.; Patel, N.; Loukogeorgakis, S.; Okorie, M.; Aboud, Z.; Misra, S.; Rashid, R.; Miall, P.; Deanfield, J.; Benjamin, N.; et al. Acute Blood Pressure Lowering, Vasoprotective, and Antiplatelet Properties of Dietary Nitrate via Bioconversion to Nitrite. Hypertension 2008, 51, 784-790. [CrossRef]

314. Coles, L.T.; Clifton, P.M. Effect of beetroot juice on lowering blood pressure in free-living, disease-free adults: A randomized, placebo-controlled trial. Nutr. J. 2012, 11, 106. [CrossRef]

315. Jajja, A.; Sutyarjoko, A.; Lara, J.; Rennie, K.; Brandt, K.; Qadir, O.; Siervo, M. Beetroot supplementation lowers daily systolic blood pressure in older, overweight subjects. Nutr. Res. 2014, 34, 868-875. [CrossRef]

316. Kapil, V.; Khambata, R.S.; Robertson, A.; Caulfield, M.J.; Ahluwalia, A. Dietary nitrate provides sustained blood pressure lowering in hypertensive patients: A randomized, phase 2, double-blind, placebo-controlled study. Hypertension 2015, 65, 320-327. [CrossRef]

317. Bailey, S.J.; Winyard, P.; Vanhatalo, A.; Blackwell, J.R.; DiMenna, F.J.; Wilkerson, D.P.; Tarr, J.; Benjamin, N.; Jones, A.M. Dietary nitrate supplementation reduces the $\mathrm{O}_{2}$ cost of low-intensity exercise and enhances tolerance to high-intensity exercise in humans. J. Appl. Physiol. 2009, 107, 1144-1155. [CrossRef]

318. Lansley, K.E.; Winyard, P.G.; Fulford, J. Dietary nitrate supplementation reduces the $\mathrm{O}_{2}$ cost of walking and running: A pla-cebocontrolled study. J. Appl. Physiol. 2011, 110, 591-600. [CrossRef]

319. Ferguson, S.K.; Holdsworth, C.T.; Colburn, T.D.; Wright, J.L.; Craig, J.C.; Fees, A.; Jones, A.M.; Allen, J.D.; Musch, T.I.; Poole, D.C. Dietary nitrate supplementation: Impact on skeletal muscle vascular control in exercising rats with chronic heart failure. J. Appl. Physiol. 2016, 121, 661-669. [CrossRef]

320. Coggan, A.R.; Leibowitz, J.L.; Spearie, C.A. Acute Dietary Nitrate Intake Improves Muscle Contractile Function in Patients with Heart Failure: A Double-Blind, Placebo-Controlled, Randomized Trial. Circ. Heart Fail. 2015, 8, 914-920. [CrossRef]

321. Eggebeen, J.; Kim-Shapiro, D.B.; Haykowsky, M. One Week of Daily Dosing with Beetroot Juice Improves Submaximal Endurance and Blood Pressure in Older Patients with Heart Failure and Preserved Ejection Fraction. JACC Heart Fail. 2016, 4, 428-437. [CrossRef]

322. Coggan, A.R.; Broadstreet, S.R.; Mahmood, K. Dietary Nitrate Increases VO2peak and Performance but Does Not Alter Ventilation or Efficiency in Patients with Heart Failure with Reduced Ejection Fraction. J. Card. Fail. 2018, 24, 65-73. [CrossRef]

323. Hirai, D.M.; Zelt, J.T.; Jones, J.H.; Castanhas, L.G.; Bentley, R.F.; Earle, W.; Staples, P.; Tschakovsky, M.E.; McCans, J.; O'Donnell, D.E.; et al. Dietary nitrate supplementation and exercise tolerance in patients with heart failure with reduced ejection fraction. Am. J. Physiol. Integr. Comp. Physiol. 2017, 312, R13-R22. [CrossRef] [PubMed]

324. Dubin, R.F.; Shah, S.J. Soluble Guanylate Cyclase Stimulators: A Novel Treatment Option for Heart Failure Associated with Cardiorenal Syndromes? Curr. Heart Fail. Rep. 2016, 13, 132-139. [CrossRef] [PubMed] 
325. Pieske, B.; Butler, J.; Filippatos, G.; Lam, C.; Maggioni, A.P.; Ponikowski, P.; Shah, S.; Solomon, S.; Kraigher-Krainer, E.; Samano, E.T.; et al. Rationale and design of the SOluble guanylate Cyclase stimulatoR in heArT failurE Studies (SOCRATES). Eur. J. Heart Fail. 2014, 16, 1026-1038. [CrossRef]

326. Gheorghiade, M.; Marti, C.N.; Sabbah, H.N.; Roessig, L.; Greene, S.J.; Boehm, M.; Burnett, J.C.; Campia, U.; Cleland, J.G.F.; Collins, S.P.; et al. Soluble guanylate cyclase: A potential therapeutic target for heart failure. Heart Fail. Rev. 2012, 18, 123-134. [CrossRef]

327. Armstrong, P.W.; Roessig, L.; Patel, M.J. A Multicenter, Randomized, Double-Blind, Placebo-Controlled Trial of the Efficacy and Safety of the Oral Soluble Guanylate Cyclase Stimulator: The VICTORIA Trial. JACC Heart Fail. 2018, 6, 96-104. [CrossRef] [PubMed]

328. Sandner, P.; Stasch, J.P. Anti-fibrotic effects of soluble guanylate cyclase stimulators and activators: A review of the preclinical evidence. Respir. Med. 2017, 122, S1-S9. [CrossRef]

329. Breitenstein, S.; Roessig, L.; Sandner, P.; Lewis, K.S. Novel sGC Stimulators and sGC Activators for the Treatment of Heart Failure. Handb. Exp. Pharmacol. 2017, 243, 225-247.

330. Vesely, D. Biotin enhances guanylate cyclase activity. Science 1982, 216, 1329-1330. [CrossRef]

331. Vesely, D.L.; Wormser, H.C.; Bramson, H.N. Biotin analogs activate guanylate cyclase. Mol. Cell. Biochem. 1984, 60, 109-114. [CrossRef]

332. Singh, I.N.; Dakshinamurti, K. Stimulation of guanylate cyclase and RNA polymerase II activities in HeLa cells and fibroblasts by biotin. Mol. Cell. Biochem. 1988, 79, 47-55. [CrossRef]

333. Watanabe-Kamiyama, M.; Kamiyama, S.; Horiuchi, K. Antihypertensive effect of biotin in stroke-prone spontaneously hypertensive rats. Br. J. Nutr. 2008, 99, 756-763. [CrossRef] [PubMed]

334. Tourbah, A.; Lebrun-Frenay, C.; Edan, G.; Clanet, M.; Papeix, C.; Vukusic, S.; De Sèze, J.; Debouverie, M.; Gout, O.; Clavelou, P.; et al. MD1003 (high-dose biotin) for the treatment of progressive multiple sclerosis: A randomised, double-blind, placebocontrolled study. Mult. Scler. J. 2016, 22, 1719-1731. [CrossRef] [PubMed]

335. McCarty, M.F.; DiNicolantonio, J.J. Neuroprotective potential of high-dose biotin. Med. Hypotheses 2017, 109, 145-149. [CrossRef] [PubMed]

336. McCarty, M.F. Supplementation with Phycocyanobilin, Citrulline, Taurine, and Supranutritional Doses of Folic Acid and Biotin-Potential for Preventing or Slowing the Progression of Diabetic Complications. Healthcare 2017, 5, 15. [CrossRef]

337. Mock, D.M. Biotin: From Nutrition to Therapeutics. J. Nutr. 2017, 147, 1487-1492. [CrossRef]

338. Zhou, Z.; Martin, E.; Sharina, I.; Esposito, I.; Szabo, C.; Bucci, M.; Cirino, G.; Papapetropoulos, A. Regulation of soluble guanylyl cyclase redox state by hydrogen sulfide. Pharmacol. Res. 2016, 111, 556-562. [CrossRef]

339. Takimoto, E.; Champion, H.C.; Li, M.; Belardi, D.F.; Ren, S.; Rodriguez, E.R.; Bedja, D.; Gabrielson, K.L.; Wang, Y.A.; Kass, D. Chronic inhibition of cyclic GMP phosphodiesterase 5A prevents and reverses cardiac hypertrophy. Nat. Med. 2005, 11, 214-222. [CrossRef] [PubMed]

340. Zhuang, X.-D.; Long, M.; Li, F.; Hu, X.; Liao, X.-X.; Du, Z.-M. PDE5 inhibitor sildenafil in the treatment of heart failure: A meta-analysis of randomized controlled trials. Int. J. Cardiol. 2014, 172, 581-587. [CrossRef]

341. Vecchis, R.; Cesaro, A.; Ariano, C. Therapeutic benefits of phosphodiesterase-5 inhibition in chronic heart failure: A meta-analysis. Interv. Med. Appl. Sci. 2017, 9, 123-135. [CrossRef]

342. De Vecchis, R.; Cesaro, A.; Ariano, C.; Giasi, A.; Cioppa, C. Phosphodiesterase-5 Inhibitors Improve Clinical Outcomes, Exercise Capacity and Pulmonary Hemodynamics in Patients with Heart Failure with Reduced Left Ventricular Ejection Fraction: A Meta-Analysis. J. Clin. Med. Res. 2017, 9, 488-498. [CrossRef] [PubMed]

343. Szabo, C. Hydrogen sulfide, an enhancer of vascular nitric oxide signaling: Mechanisms and implications. Am. J. Physiol. Physiol. 2017, 312, C3-C15. [CrossRef]

344. Endo, J.; Arita, M. Cardioprotective mechanism of omega-3 polyunsaturated fatty acids. J. Cardiol. 2016, 67, 22-27. [CrossRef] [PubMed]

345. Leaf, A.; Xiao, Y.-F.; Kang, J.; Billman, G. Membrane Effects of the n-3 Fish Oil Fatty Acids, which Prevent Fatal Ventricular Arrhythmias. J. Membr. Biol. 2005, 206, 129-139. [CrossRef]

346. Xiao, Y.-F.; Sigg, D.; Leaf, A. The Antiarrhythmic Effect of n-3 Polyunsaturated Fatty Acids: Modulation of Cardiac Ion Channels as a Potential Mechanism. J. Membr. Biol. 2005, 206, 141-154. [CrossRef] [PubMed]

347. Chen, J.; Shearer, G.C.; Chen, Q.; Healy, C.L.; Beyer, A.J.; Nareddy, V.B.; Gerdes, A.M.; Harris, W.S.; O'Connell, T.D.; Wang, D. Omega-3 Fatty Acids Prevent Pressure Overload-Induced Cardiac Fibrosis through Activation of Cyclic GMP/Protein Kinase G Signaling in Cardiac Fibroblasts. Circulation 2011, 123, 584-593. [CrossRef]

348. Eclov, J.A.; Qian, Q.; Redetzke, R.; Chen, Q.; Wu, S.C.; Healy, C.L.; Ortmeier, S.B.; Harmon, E.; Shearer, G.C.; O'Connell, T.D. EPA, not DHA, prevents fibrosis in pressure overload-induced heart failure: Potential role of free fatty acid receptor 4 . J. Lipid Res. 2015, 56, 2297-2308. [CrossRef]

349. O'Connell, T.D.; Block, R.C.; Huang, S.P.; Shearer, G.C. Omega3-Polyunsaturated fatty acids for heart failure: Effects of dose on efficacy and novel signaling through free fatty acid receptor 4. J. Mol. Cell. Cardiol. 2017, 103, 74-92. [CrossRef] [PubMed]

350. Ohnishi, H.; Saito, Y. Eicosapentaenoic Acid (EPA) Reduces Cardiovascular Events: Relationship with the EPA/Arachidonic Acid Ratio. J. Atheroscler. Thromb. 2013, 20, 861-877. [CrossRef] 
351. Fischer, S.; Weber, P.C. Prostaglandin I3 is formed in vivo in man after dietary eicosapentaenoic acid. Nature 1984, $307,165-168$. [CrossRef] [PubMed]

352. Knapp, H.R.; Reilly, I.A.; Alessandrini, P.; Fitzgerald, G.A. In Vivo Indexes of Platelet and Vascular Function during Fish-Oil Administration in Patients with Atherosclerosis. N. Engl. J. Med. 1986, 314, 937-942. [CrossRef] [PubMed]

353. Kobzar, G.; Mardla, V.; Järving, I.; Samel, N. Comparison of anti-aggregatory effects of PGI2, PGI3 and iloprost on human and rabbit platelets. Cell. Physiol. Biochem. 2001, 11, 279-284. [CrossRef]

354. Watanabe, S.; Yoshihisa, A.; Kanno, Y.; Takiguchi, M.; Yokokawa, T.; Sato, A.; Miura, S.; Shimizu, T.; Abe, S.; Sato, T.; et al. Associations with Eicosapentaenoic Acid to Arachidonic Acid Ratio and Mortality in Hospitalized Heart Failure Patients. J. Card. Fail. 2016, 22, 962-969. [CrossRef]

355. Nagahara, Y.; Motoyama, S.; Sarai, M.; Ito, H.; Kawai, H.; Takakuwa, Y.; Miyagi, M.; Shibata, D.; Takahashi, H.; Naruse, H.; et al. Eicosapentaenoic acid to arachidonic acid (EPA/AA) ratio as an associated factor of high risk plaque on coronary computed tomography in patients without coronary artery disease. Atherosclerosis 2016, 250, 30-37. [CrossRef]

356. Hasegawa, T.; Otsuka, K.; Iguchi, T.; Matsumoto, K.; Ehara, S.; Nakata, S.; Nishimura, S.; Kataoka, T.; Shimada, K.; Yoshiyama, M. Serum n-3 to n-6 polyunsaturated fatty acids ratio correlates with coronary plaque vulnerability: An optical coherence tomography study. Heart Vessels 2013, 29, 596-602. [CrossRef]

357. Yagi, S.; Aihara, K.-I.; Fukuda, D.; Takashima, A.; Bando, M.; Hara, T.; Nishimoto, S.; Ise, T.; Kusunose, K.; Yamaguchi, K.; et al. Reduced ratio of eicosapentaenoic acid and docosahexaenoic acid to arachidonic acid is associated with early onset of acute coronary syndrome. Nutr. J. 2015, 14, 111. [CrossRef]

358. Kramer, H.; Stevens, J.; Grimminger, F.; Seeger, W. Fish oil fatty acids and human platelets: Dose-dependent decrease in dienoic and increase in trienoic thromboxane generation. Biochem. Pharmacol. 1996, 52, 1211-1217. [CrossRef]

359. Shah, K.B.; Duda, M.K.; O'Shea, K.M. The cardioprotective effects of fish oil during pressure overload are blocked by high fat intake: Role of cardiac phospholipid remodeling. Hypertension 2009, 54, 605-611. [CrossRef]

360. Kunutsor, S.K.; Khan, H.; Laukkanen, J.A. Serum magnesium and risk of new onset heart failure in men: The Kuopio Ischemic Heart Disease Study. Eur. J. Epidemiol. 2016, 31, 1035-1043. [CrossRef] [PubMed]

361. Reffelmann, T.; Dörr, M.; Ittermann, T.; Schwahn, C.; Völzke, H.; Ruppert, J.; Robinson, D.; Felix, S.B. Low serum magnesium concentrations predict increase in left ventricular mass over 5 years independently of common cardiovascular risk factors. Atherosclerosis 2010, 213, 563-569. [CrossRef]

362. Joao, M.P.; Azevedo, A.; Laranjinha, I. Lower serum magnesium is associated with cardiovascular risk factors and mortality in haemodialysis patients. Blood Purif. 2014, 38, 244-252. [CrossRef] [PubMed]

363. Lutsey, P.L.; Alonso, A.; Michos, E.D.; Loehr, L.R.; Astor, B.C.; Coresh, J.; Folsom, A.R. Serum magnesium, phosphorus, and calcium are associated with risk of incident heart failure: The Atherosclerosis Risk in Communities (ARIC) Study. Am. J. Clin. Nutr. 2014, 100, 756-764. [CrossRef]

364. Zhang, W.; Iso, H.; Ohira, T.; Date, C.; Tamakoshi, A. Associations of dietary magnesium intake with mortality from cardiovascular disease: The JACC study. Atherosclerosis 2012, 221, 587-595. [CrossRef]

365. Fang, X.; Wang, K.; Han, D.; He, X.; Wei, J.; Zhao, L.; Imam, M.U.; Ping, Z.; Li, Y.; Xu, Y.; et al. Dietary magnesium intake and the risk of cardiovascular disease, type 2 diabetes, and all-cause mortality: A dose-response meta-analysis of prospective cohort studies. BMC Med. 2016, 14, 1-13. [CrossRef]

366. Taveira, T.H.; Ouellette, D.; Gulum, A. Relation of Magnesium Intake with Cardiac Function and Heart Failure Hospitali-zations in Black Adults: The Jackson Heart Study. Circ. Heart Fail. 2016, 9, e002698. [CrossRef] [PubMed]

367. Douban, S.; Brodsky, M.A.; Whang, D.D.; Whang, R. Significance of magnesium in congestive heart failure. Am. Heart J. 1996, 132, 664-671. [CrossRef]

368. Ohki, S.-Y.; Ikura, M.; Zhang, M. Identification of $\mathrm{Mg}^{2+}$-Binding Sites and the Role of $\mathrm{Mg}^{2+}$ on Target Recognition by Calmodulin. Biochemistry 1997, 36, 4309-4316. [CrossRef] [PubMed]

369. Malmendal, A.; Linse, S.; Evenas, J.; Forsen, S.; Drakenberg, T. Battle for the EF-hands: Magnesium-calcium interference in calmodulin. Biochemistry 1999, 38, 11844-11850. [CrossRef] [PubMed]

370. Grabarek, Z. Insights into modulation of calcium signaling by magnesium in calmodulin, troponin C and related EF-hand proteins. Biochim. Biophys. Acta 2011, 1813, 913-921. [CrossRef]

371. Kawano, S. Dual mechanisms of $\mathrm{Mg}^{2+}$ block of ryanodine receptor $\mathrm{Ca}^{2+}$ release channel from cardiac sarcoplasmic reticulum. Recept. Channels 1998, 5, 405-416. [PubMed]

372. Bertinato, J.; Lavergne, C.; Plouffe, L.J.; El Niaj, H.A. Small increases in dietary calcium above normal requirements exacerbate magnesium deficiency in rats fed a low magnesium diet. Magnes. Res. 2014, 27, 35-47. [CrossRef]

373. DiNicolantonio, J.J.; Mccarty, M.F.; O'Keefe, J.H. Decreased magnesium status may mediate the increased cardiovascular risk associated with calcium supplementation. Open Heart 2017, 4, e000617. [CrossRef] [PubMed]

374. Kircelli, F.; Peter, M.E.; Ok, E.S.; Celenk, F.G.; Yilmaz, M.; Steppan, S.; Asci, G.; Passlick-Deetjen, J. Magnesium reduces calcification in bovine vascular smooth muscle cells in a dose-dependent manner. Nephrol. Dial. Transplant. 2011, 27, 514-521. [CrossRef] [PubMed]

375. Louvet, L.; Büchel, J.; Steppan, S.; Passlick-Deetjen, J.; Massy, Z.A. Magnesium prevents phosphate-induced calcification in human aortic vascular smooth muscle cells. Nephrol. Dial. Transplant. 2012, 28, 869-878. [CrossRef] [PubMed] 
376. Ter Braake, A.D.; Shanahan, C.M.; de Baaij, J.H.F. Magnesium Counteracts Vascular Calcification: Passive Interference or Active Modulation? Arterioscler. Thromb. Vasc. Biol. 2017, 37, 1431-1445. [CrossRef]

377. Ishimura, E.; Okuno, S.; Kitatani, K.; Tsuchida, T.; Yamakawa, T.; Shioi, A.; Inaba, M.; Nishizawa, Y. Significant association between the presence of peripheral vascular calcification and lower serum magnesium in hemodialysis patients. Clin. Nephrol. 2007, 68, 222-227. [CrossRef]

378. Meema, H.E.; Oreopoulos, D.G.; Rapoport, A. Serum magnesium level and arterial calcification in end-stage renal disease. Kidney Int. 1987, 32, 388-394. [CrossRef]

379. Massy, Z.A.; Drüeke, T.B. Magnesium and outcomes in patients with chronic kidney disease: Focus on vascular calcification, atherosclerosis and survival. Clin. Kidney J. 2012, 5, i52-i61. [CrossRef]

380. Lee, S.Y.; Hyun, Y.Y.; Lee, K.B.; Kim, H. Low serum magnesium is associated with coronary artery calcification in a Korean population at low risk for cardiovascular disease. Nutr. Metab. Cardiovasc. Dis. 2015, 25, 1056-1061. [CrossRef] [PubMed]

381. Sakaguchi, Y.; Hamano, T.; Isaka, Y. Effects of Magnesium on the Phosphate Toxicity in Chronic Kidney Disease: Time for Intervention Studies. Nutrients 2017, 9, 112. [CrossRef]

382. Schurgers, L.; Dissel, P.; Spronk, H.; Soute, B.; Dhore, C.; Cleutjens, J.; Vermeer, C. Role of vitamin K and vitamin K-dependent proteins in vascular calcification. Zeitschrift für Kardiologie 2001, 90, III57-III63. [CrossRef]

383. Shea, M.K.; Holden, R.M. Vitamin K Status and Vascular Calcification: Evidence from Observational and Clinical Studies. Adv. Nutr. 2012, 3, 158-165. [CrossRef] [PubMed]

384. Vossen, L.M.; Schurgers, L.J.; van Varik, B.J. Menaquinone-7 Supplementation to Reduce Vascular Calcification in Patients with Coronary Artery Disease: Rationale and Study Protocol (VitaK-CAC Trial). Nutrients 2015, 7, 8905-8915. [CrossRef] [PubMed]

385. Beulens, J.W.J.; Booth, S.L.; van den Heuvel, E.G.; Stoecklin, E.; Baka, A.; Vermeer, C. The role of menaquinones (vitamin $\mathrm{K}_{2}$ ) in human health. Br. J. Nutr. 2013, 110, 1357-1368. [CrossRef]

386. Geiss, K.R.; Stergiou, N.; Neuenfeld, H.U.J.; Jester, H.G. Effects of magnesium orotate on exercise tolerance in patients with coronary heart disease. Cardiovasc. Drugs Ther. 1998, 12 (Suppl. 2), 153-156. [CrossRef] [PubMed]

387. Jasmin, G.; Proschek, L. Effect of orotic acid and magnesium orotate on the development and progression of the UM-X7.1 hamster hereditary cardiomyopathy. Cardiovasc. Drugs Ther. 1998, 12, 189-195. [CrossRef]

388. Branea, I.; Gaiţă, D.; Drăgulescu, I.; Socoteanu, I.; Luca, C.; Mancaş, S.; DrĂgan, S.; Iurciuc, M.; Velimirovici, D.; Gaşpar, M.; et al. Assessment of treatment with orotate magnesium in early postoperative period of patients with cardiac insufficiency and coronary artery by-pass grafts (ATOMIC). Rom. J. Intern. Med. 2004, 37, 287-296.

389. Rosenfeldt, F.L. Editorial: Metabolic Supplementation with Orotic Acid and Magnesium Orotate. Cardiovasc. Drugs Ther. 1998, 12, 147-152. [CrossRef]

390. Stepura, O.B.; Martynow, A.I. Magnesium orotate in severe congestive heart failure (MACH). Int. J. Cardiol. 2009, 134, 145-147. [CrossRef]

391. Aonuma, S.; Hama, T.; Tamaki, N.; Okumura, H. Orotate as a beta-alanine donor for anserine and carnosine biosynthesis, and effects of actinomycin D and azauracil on their pathway. J. Biochem. 1969, 66, 123-132. [CrossRef]

392. McCarty, M.F.; DiNicolantonio, J.J. Beta-Alanine and orotate as supplements for cardiac protection. Open Heart 2014,1 , e000119. [CrossRef]

393. Alabovsky, V.V.; Boldyrev, A.A.; Vinokurov, A.A.; VKh, S. Effect of histidine-containing dipeptides on isolated heart under ischemia/reperfusion. Biochem. Biokhimiia 1997, 62, 77-87.

394. Sale, C.; Saunders, B.; Harris, R.C. Effect of beta-alanine supplementation on muscle carnosine concentrations and exercise performance. Amino Acids 2009, 39, 321-333. [CrossRef]

395. Saunders, B.; Elliott-Sale, K.; Artioli, G.G. Beta-alanine supplementation to improve exercise capacity and performance: A systematic review and meta-analysis. Br. J. Sports Med. 2017, 51, 658-669. [CrossRef] [PubMed]

396. Lombardi, C.; Carubelli, V.; Lazzarini, V.; Vizzardi, E.; Bordonali, T.; Ciccarese, C.; Castrini, A.I.; Cas, A.D.; Nodari, S.; Metra, M. Effects of oral administration of orodispersible levo-carnosine on quality of life and exercise performance in patients with chronic heart failure. Nutrition 2015, 31, 72-78. [CrossRef]

397. Everaert, I.; Taes, Y.; De Heer, E.; Baelde, H.; Zutinic, A.; Yard, B.; Sauerhöfer, S.; Vanhee, L.; Delanghe, J.; Aldini, G.; et al. Low plasma carnosinase activity promotes carnosinemia after carnosine ingestion in humans. Am. J. Physiol. Physiol. 2012, 302, F1537-F1544. [CrossRef] [PubMed]

398. Koeth, R.A.; Wang, Z.; Levison, B.S.; Buffa, J.A.; Org, E.; Sheehy, B.T.; Britt, E.B.; Fu, X.; Wu, Y.; Li, L.; et al. Intestinal microbiota metabolism of 1-carnitine, a nutrient in red meat, promotes atherosclerosis. Nat. Med. 2013, 19, 576-585. [CrossRef]

399. DiNicolantonio, J.J.; Lavie, C.J.; Fares, H.; Menezes, A.R.; O'Keefe, J.H. L-Carnitine in the Secondary Prevention of Cardiovascular Disease: Systematic Review and Meta-analysis. Mayo Clin. Proc. 2013, 88, 544-551. [CrossRef] [PubMed]

400. Shang, R.; Sun, Z.; Li, H. Effective dosing of L-carnitine in the secondary prevention of cardiovascular disease: A systematic review and meta-analysis. BMC Cardiovasc. Disord. 2014, 14, 88. [CrossRef]

401. Mccarty, M.F. L-Carnitine Consumption, Its Metabolism by Intestinal Microbiota, and Cardiovascular Health. Mayo Clin. Proc. 2013, 88, 786-789. [CrossRef] [PubMed]

402. Song, X.; Qu, H.; Yang, Z.; Rong, J.; Cai, W.; Zhou, H. Efficacy and Safety of L-Carnitine Treatment for Chronic Heart Failure: A Meta-Analysis of Randomized Controlled Trials. BioMed Res. Int. 2017, 2017, 6274854. [CrossRef] 
403. Pettit, F.H.; Pelley, J.W.; Reed, L.J. Regulation of pyruvate dehydrogenase kinase and phosphatase by acetyl-CoA/CoA and NADH/NAD ratios. Biochem. Biophys. Res. Commun. 1975, 65, 575-582. [CrossRef]

404. Calvani, M.; Reda, E.; Arrigoni-Martelli, E. Regulation by carnitine of myocardial fatty acid and carbohydrate metabolism under normal and pathological conditions. Basic Res. Cardiol. 2000, 95, 75-83. [CrossRef] [PubMed]

405. Karmazyn, M.; Moffat, M.P. Role of $\mathrm{Na}+\mathrm{H}+$ exchange in cardiac physiology and pathophysiology: Mediation of myocardial reperfusion injury by the $\mathrm{pH}$ paradox. Cardiovasc. Res. 1993, 27, 915-924. [CrossRef]

406. Stvolinsky, S.L.; Dobrota, D. Anti-ischemic activity of carnosine. Biochemistry 2000, 65, 849-855.

407. Azuma, J.; Sawamura, A.; Awata, N.; Ohta, H.; Hamaguchi, T.; Harada, H.; Takihara, K.; Hasegawa, H.; Yamagami, T.; Ishiyama, T.; et al. Therapeutic effect of taurine in congestive heart failure: A double-blind crossover trial. Clin. Cardiol. 1985, 8, 276-282. [CrossRef] [PubMed]

408. Azuma, J.; Hasegawa, H.; Sawamura, A.; Awata, N.; Ogura, K.; Harada, H.; Yamamura, Y.; Kishimoto, S. Therapy of congestive heart failure with orally administered taurine. Clin. Ther. 1983, 5, 398-408.

409. Beyranvand, M.R.; Khalafi, M.K.; Roshan, V.D.; Choobineh, S.; Parsa, S.A.; Piranfar, M.A. Effect of taurine supplementation on exercise capacity of patients with heart failure. J. Cardiol. 2011, 57, 333-337. [CrossRef]

410. Azuma, J.; Sawamura, A.; Awata, N. Usefulness of Taurine in Chronic Congestive Heart Failure and Its Prospective Application. Jpn. Circ. J. 1992, 56, 95-99. [CrossRef] [PubMed]

411. Azuma, J.; Takihara, K.; Awata, N. Beneficial effect of taurine on congestive heart failure induced by chronic aortic regur-gitation in rabbits. Res. Commun. Chem. Pathol. Pharmacol. 1984, 45, 261-270.

412. Takihara, K.; Azuma, J.; Awata, N.; Ohta, H.; Hamaguchi, T.; Sawamura, A.; Tanaka, Y.; Kishimoto, S.; Sperelakis, N. Beneficial effect of taurine in rabbits with chronic congestive heart failure. Am. Heart J. 1986, 112, 1278-1284. [CrossRef]

413. Pion, P.D.; Kittleson, M.D.; Skiles, M.L.; Rogers, Q.R.; Morris, J.G. Dilated Cardiomyopathy Associated with Taurine Deficiency in the Domestic Cat: Relationship to Diet and Myocardial Taurine Content. Tissue Eng. 1992, 315, 63-73. [CrossRef]

414. Ito, T.; Kimura, Y.; Uozumi, Y. Taurine depletion caused by knocking out the taurine transporter gene leads to cardiomyo-pathy with cardiac atrophy. J. Mol. Cell. Cardiol. 2008, 44, 927-937. [CrossRef] [PubMed]

415. Sun, Q.; Wang, B.; Li, Y. Taurine Supplementation Lowers Blood Pressure and Improves Vascular Function in Prehyper-tension: Randomized, Double-Blind, Placebo-Controlled Study. Hypertension 2016, 67, 541-549. [CrossRef]

416. Yamori, Y.; Taguchi, T.; Hamada, A.; Kunimasa, K.; Mori, H.; Mori, M. Taurine in health and diseases: Consistent evidence from experimental and epidemiological studies. J. Biomed. Sci. 2010, 17, S6. [CrossRef] [PubMed]

417. Murakami, S. Taurine and atherosclerosis. Amino Acids 2014, 46, 73-80. [CrossRef] [PubMed]

418. Abebe, W.; Mozaffari, M.S. Role of taurine in the vasculature: An overview of experimental and human studies. Am. J. Cardiovasc. Dis. 2011, 1, 293-311.

419. Wang, H.D.; Lu, X.X.; Lu, D.X. Glycine inhibits the LPS-induced increase in cytosolic $\mathrm{Ca}^{2+}$ concentration and TNFalpha production in cardiomyocytes by activating a glycine receptor. Acta Pharmacol. Sin. 2009, 30, 1107-1114. [CrossRef]

420. Zhong, Z.; Wheeler, M.D.; Li, X.; Froh, M.; Schemmer, P.; Yin, M.; Bunzendaul, H.; Bradford, B.; Lemasters, J.J. L-Glycine: A novel antiinflammatory, immunomodulatory, and cytoprotective agent. Curr. Opin. Clin. Nutr. Metab. Care 2003, 6, 229-240. [CrossRef]

421. Mccarty, M.F.; DiNicolantonio, J.J. The cardiometabolic benefits of glycine: Is glycine an 'antidote' to dietary fructose? Open Heart 2014, 1, e000103. [CrossRef] [PubMed]

422. Lu, Y.; Zhu, X.; Li, J.; Fang, R.; Wang, Z.; Zhang, J.; Li, K.; Li, X.; Bai, H.; Yang, Q.; et al. Glycine prevents pressure overload induced cardiac hypertrophy mediated by glycine receptor. Biochem. Pharmacol. 2017, 123, 40-51. [CrossRef] [PubMed]

423. Zhong, X.; Li, X.; Qian, L. Glycine attenuates myocardial ischemia-reperfusion injury by inhibiting myocardial apoptosis in rats. J. Biomed. Res. 2012, 26, 346-354. [CrossRef] [PubMed]

424. Schemmer, P.; Zhong, Z.; Galli, U.; Wheeler, M.D.; Xiangli, L.; Bradford, B.U.; Conzelmann, L.O.; Forman, D.; Boyer, J.; Thurman, R.G. Glycine reduces platelet aggregation. Amino Acids 2012, 44, 925-931. [CrossRef]

425. Ding, Y.; Svingen, G.F.T.; Pedersen, E.R.; Gregory, J.F.; Ueland, P.M.; Tell, G.S.; Nygård, O.K. Plasma Glycine and Risk of Acute Myocardial Infarction in Patients With Suspected Stable Angina Pectoris. J. Am. Heart Assoc. 2016, 5, e002621. [CrossRef]

426. Hughes, W.M., Jr.; Rodriguez, W.E.; Rosenberger, D. Role of copper and homocysteine in pressure overload heart failure. Cardiovasc. Toxicol. 2008, 8, 137-144. [CrossRef]

427. Feng, W.; Ye, F.; Xue, W.; Zhou, Z.; Kang, Y.J. Copper Regulation of Hypoxia-Inducible Factor-1 Activity. Mol. Pharmacol. 2008, 75, 174-182. [CrossRef]

428. Wang, T.; Li, R.; Lin, C.; Sun, M.; Kang, Y.J. Brief Communication: Copper suppression of vascular endothelial growth factor receptor-2 is involved in the regression of cardiomyocyte hypertrophy. Exp. Biol. Med. 2014, 239, 948-953. [CrossRef]

429. Zheng, L.; Han, P.; Liu, J.; Li, R.; Yin, W.; Wang, T.; Zhang, W.; Kang, Y.J. Role of copper in regression of cardiac hypertrophy. Pharmacol. Ther. 2015, 148, 66-84. [CrossRef]

430. Witte, K.K.; Nikitin, N.P.; Parker, A.C.; Von Haehling, S.; Volk, H.-D.; Anker, S.D.; Clark, A.L.; Cleland, J.G. The effect of micronutrient supplementation on quality-of-life and left ventricular function in elderly patients with chronic heart failure. Eur. Heart J. 2005, 26, 2238-2244. [CrossRef]

431. Klevay, L.M. Heart failure improvement from a supplement containing copper. Eur. Heart J. 2005, 27, 117. [CrossRef] 
432. Zhang, S.; Liu, H.; Amarsingh, G.V.; Cheung, C.C.H.; Hogl, S.; Narayanan, U.; Zhang, L.; McHarg, S.; Xu, J.; Gong, D.; et al. Diabetic cardiomyopathy is associated with defective myocellular copper regulation and both defects are rectified by divalent copper chelation. Cardiovasc. Diabetol. 2014, 13, 100. [CrossRef] [PubMed]

433. Brewer, G.J. Zinc acetate for the treatment of Wilson's disease. Expert Opin. Pharmacother. 2001, 2, 1473-1477. [CrossRef] [PubMed]

434. McMahon, D.J.; Carrelli, A.; Palmeri, N. Effect of Parathyroidectomy upon Left Ventricular Mass in Primary Hyperparathyroidism: A Meta-Analysis. J. Clin. Endocrinol. Metab. 2015, 100, 4399-4407. [CrossRef]

435. Smogorzewski, M.; Zayed, M.; Zhang, Y.B.; Roe, J.; Massry, S.G. Parathyroid hormone increases cytosolic calcium concentration in adult rat cardiac myocytes. Am. J. Physiol. Circ. Physiol. 1993, 264, H1998-H2006. [CrossRef] [PubMed]

436. Fallo, F.; Catena, C.; Camozzi, V.; Luisetto, G.; Cosma, C.; Plebani, M.; Lupia, M.; Tona, F.; Sechi, L. Low serum 25-hydroxyvitamin D levels are associated with left ventricular hypertrophy in essential hypertension. Nutr. Metab. Cardiovasc. Dis. 2012, 22, 871-876. [CrossRef] [PubMed]

437. Costanzo, S.; De, C.A.; Di, C.A. Serum vitamin D deficiency and risk of hospitalization for heart failure: Prospective results from the Moli-sani study. Nutr. Metab. Cardiovasc. Dis. 2018, 28, 298-307. [CrossRef]

438. Zhu, K.; Knuiman, M.; Divitini, M.; Hung, J.; Lim, E.M.; Cooke, B.R.; Walsh, J.P. Serum 25-hydroxyvitamin D as a predictor of mortality and cardiovascular events: A 20-year study of a community-based cohort. Clin. Endocrinol. 2018, 88, 154-163. [CrossRef]

439. Lutsey, P.L.; Michos, E.D.; Misialek, J.R. Race and Vitamin D Binding Protein Gene Polymorphisms Modify the Association of 25-Hydroxyvitamin D and Incident Heart Failure: The ARIC (Atherosclerosis Risk in Communities) Study. JACC Heart Fail. 2015, 3, 347-356. [CrossRef]

440. Li, Y.; Chen, C.; Liu, H.; Qian, G. Vitamin D, Parathyroid Hormone, and Heart Failure in a Chinese Elderly Population. Endocr. Pract. 2015, 21, 30-40. [CrossRef]

441. Welles, C.C.; Whooley, M.A.; Karumanchi, S.A.; Hod, T.; Thadhani, R.; Berg, A.H.; Ix, J.H.; Mukamal, K.J. Vitamin D deficiency and cardiovascular events in patients with coronary heart disease: Data from the Heart and Soul Study. Am. J. Epidemiol. 2014, 179, 1279-1287. [CrossRef]

442. Jiang, W.-L.; Gu, H.-B.; Zhang, Y.-F.; Xia, Q.-Q.; Qi, J.; Chen, J.-C. Vitamin D Supplementation in the Treatment of Chronic Heart Failure: A Meta-analysis of Randomized Controlled Trials. Clin. Cardiol. 2016, 39, 56-61. [CrossRef]

443. D'Amore, C.; Marsico, F.; Parente, A.; Paolillo, S.; De Martino, F.; Gargiulo, P.; Ferrazzano, F.; De Roberto, A.; La Mura, L.; Marciano, C.; et al. Vitamin D deficiency and clinical outcome in patients with chronic heart failure: A review. Nutr. Metab. Cardiovasc. Dis. 2017, 27, 837-849. [CrossRef]

444. Agarwal, M.; Phan, A.; Willix, R.; Barber, M., Jr.; Schwarz, E.R. Is vitamin D deficiency associated with heart failure? A review of current evidence. J. Cardiovasc. Pharmacol. Ther. 2011, 16, 354-363. [CrossRef] [PubMed]

445. De Boer, R.A.; Meems, L.M.G.; van Veldhuisen, D.J. Vitamin D supplementation in heart failure: Case closed? Eur. Heart J. 2017, 38, 2287-2289. [CrossRef]

446. Afzal, S.; Brondum-Jacobsen, P.; Bojesen, S.E.; Nordestgaard, B.G. Genetically low vitamin D concentrations and increased mortality: Mendelian randomisation analysis in three large cohorts. BMJ 2014, 349, g6330. [CrossRef] [PubMed]

447. Halldin, M.; Fahlstadius, P.; de Faire, U.; Vikstrom, M.; Hellenius, M.L. The metabolic syndrome and left ventricular hypertrophy-The influence of gender and physical activity. Blood Press. 2012, 21, 153-160. [CrossRef] [PubMed]

448. Salvetti, G.; Pucci, A.; Fierabracci, P. Prevalence of left ventricular hypertrophy and determinants of left ventricular mass in obese women. High Blood Press. Cardiovasc. Prev. 2012, 19, 33-39. [CrossRef] [PubMed]

449. Gupta, R.K.; Gupta, R.; Makar, N.; Chaudhary, S.; Bhatheja, H.; Pathak, P. The Association of Left Ventricular Mass Index with Metabolic Syndrome in Comparison to Hypertensive Patients. J. Cardiovasc. Echogr. 2016, 26, 42-47. [CrossRef] [PubMed]

450. Al-Daydamony, M.M.; El-Tahlawi, M. What Is the Effect of Metabolic Syndrome without Hypertension on Left Ventricular Hypertrophy? Echocardiography 2016, 33, 1284-1289. [CrossRef]

451. Sukmoko, S.; Waspadji, S.; Alwi, I.; Nainggolan, G. Correlation between left ventricular mass and visceral fat thickness in obese women. Acta Med. Indones. 2006, 38, 135-141.

452. Rider, O.J.; Francis, J.M.; Ali, M.K.; Byrne, J.; Clarke, K.; Neubauer, S.; Petersen, S.E. Determinants of left ventricular mass in obesity; a cardiovascular magnetic resonance study. J. Cardiovasc. Magn. Reson. 2009, 11, 9. [CrossRef]

453. Neeland, I.J.; Gupta, S.; Ayers, C.R.; Turer, A.T.; Rame, J.E.; Das, S.R.; Berry, J.D.; Khera, A.; McGuire, D.K.; Vega, G.L.; et al. Relation of Regional Fat Distribution to Left Ventricular Structure and Function. Circ. Cardiovasc. Imaging 2013, 6, 800-807. [CrossRef]

454. Tenenbaum, A.; Fisman, E.Z.; Schwammenthal, E.; Adler, Y.; Benderly, M.; Motro, M.; Shemesh, J. Increased prevalence of left ventricular hypertrophy in hypertensive women with type 2 diabetes mellitus. Cardiovasc. Diabetol. 2003, 2, 14. [CrossRef]

455. De Kreutzenberg, S.V.; Avogaro, A.; Tiengo, A.; Del Prato, S. Left ventricular mass in type 2 diabetes mellitus. A study employing a simple ECG index: The Cornell voltage. J. Endocrinol. Investig. 2000, 23, 139-144. [CrossRef]

456. Sato, A.; Tarnow, L.; Nielsen, F.; Knudsen, E.; Parving, H.-H. Left ventricular hypertrophy in normoalbuminuric type 2 diabetic patients not taking antihypertensive treatment. QJM Int. J. Med. 2005, 98, 879-884. [CrossRef]

457. Eguchi, K.; Boden-Albala, B.; Jin, Z.; Rundek, T.; Sacco, R.L.; Homma, S.; Di Tullio, M.R. Association Between Diabetes Mellitus and Left Ventricular Hypertrophy in a Multiethnic Population. Am. J. Cardiol. 2008, 101, 1787-1791. [CrossRef]

458. Frantz, S.; Kobzik, L.; Kim, Y.-D.; Fukazawa, R.; Medzhitov, R.; Lee, R.T.; Kelly, R.A. Toll4 (TLR4) expression in cardiac myocytes in normal and failing myocardium. J. Clin. Investig. 1999, 104, 271-280. [CrossRef] 
459. Sokolova, M.; Vinge, L.E.; Alfsnes, K.; Olsen, M.B.; Eide, L.; Kaasbøll, O.J.; Attramadal, H.; Torp, M.-K.; Fosshaug, L.E.; Rashidi, A.; et al. Palmitate promotes inflammatory responses and cellular senescence in cardiac fibroblasts. Biochim. Biophys. Acta 2017, 1862, 234-245. [CrossRef]

460. Li, W.; Fang, Q.; Zhong, P.; Chen, L.; Wang, L.; Zhang, Y.; Wang, J.; Li, X.; Wang, Y.; Wang, J.; et al. EGFR Inhibition Blocks Palmitic Acid-induced inflammation in cardiomyocytes and Prevents Hyperlipidemia-induced Cardiac Injury in Mice. Sci. Rep. 2016, 6, 24580. [CrossRef]

461. Zhong, P.; Quan, D.; Peng, J.; Xiong, X.; Liu, Y.; Kong, B.; Huang, H. Role of CaMKII in free fatty acid/hyperlipidemia-induced cardiac remodeling both in vitro and in vivo. J. Mol. Cell. Cardiol. 2017, 109, 1-16. [CrossRef] [PubMed]

462. Hu, N.; Zhang, Y. TLR4 knockout attenuated high fat diet-induced cardiac dysfunction via NF-kappaB/JNK-dependent activation of autophagy. Biochim. Biophys. Acta 2017, 1863, 2001-2011. [CrossRef] [PubMed]

463. Angeli, F.; Verdecchia, P.; Pellegrino, C. Association between periodontal disease and left ventricle mass in essential hypertension. Hypertension 2003, 41, 488-492. [CrossRef] [PubMed]

464. Suzuki, J.-I.; Sato, H.; Kaneko, M.; Yoshida, A.; Aoyama, N.; Akimoto, S.; Wakayama, K.; Kumagai, H.; Ikeda, Y.; Akazawa, H.; et al. Periodontitis and myocardial hypertrophy. Hypertens. Res. 2016, 40, 324-328. [CrossRef]

465. Fröhlich, H.; Herrmann, K.; Franke, J.; Karimi, A.; Täger, T.; Cebola, R.; Katus, H.A.; Zugck, C.; Frankenstein, L. Periodontitis in Chronic Heart Failure. Tex. Heart Inst. J. 2016, 43, 297-304. [CrossRef]

466. Fallach, R.; Shainberg, A.; Avlas, O.; Fainblut, M.; Chepurko, Y.; Porat, E.; Hochhauser, E. Cardiomyocyte Toll-like receptor 4 is involved in heart dysfunction following septic shock or myocardial ischemia. J. Mol. Cell. Cardiol. 2010, 48, 1236-1244. [CrossRef]

467. Avlas, O.; Fallach, R.; Shainberg, A.; Porat, E.; Hochhauser, E. Toll-like receptor 4 stimulation initiates an inflammatory response that decreases cardiomyocyte contractility. Antioxid. Redox Signal. 2011, 15, 1895-1909. [CrossRef]

468. Yu, J.; Lu, Y.; Li, Y. Role of S100A1 in hypoxia-induced inflammatory response in cardiomyocytes via TLR4/ROS/NF-kappaB pathway. J. Pharm. Pharmacol. 2015, 67, 1240-1250. [CrossRef]

469. Liu, L.; Wang, Y.; Cao, Z.Y. Up-regulated TLR4 in cardiomyocytes exacerbates heart failure after long-term myocardial in-farction. J. Cell. Mol. Med. 2015, 19, 2728-2740. [CrossRef]

470. Knowlton, A.A. Paying for the Tolls: The High Cost of the Innate Immune System for the Cardiac Myocyte. Adv. Exp. Med. Biol. 2017, 1003, 17-34. [CrossRef]

471. Yang, J.; Zhang, R.; Jiang, X.; Lv, J.; Li, Y.; Ye, H.; Liu, W.; Wang, G.; Zhang, C.; Zheng, N.; et al. Toll-like receptor 4-induced ryanodine receptor 2 oxidation and sarcoplasmic reticulum $\mathrm{Ca}^{2+}$ leakage promote cardiac contractile dysfunction in sepsis. J. Biol. Chem. 2018, 293, 794-807. [CrossRef] [PubMed]

472. Katare, P.B.; Bagul, P.K.; Dinda, A.K.; Banerjee, S.K. Toll-Like Receptor 4 Inhibition Improves Oxidative Stress and Mito-chondrial Health in Isoproterenol-Induced Cardiac Hypertrophy in Rats. Front. Immunol 2017, 8, 719. [CrossRef]

473. Zhang, C.; Mo, M.; Ding, W.; Liu, W.; Yan, D.; Deng, J.; Luo, X.; Liu, J. High-mobility group box 1 (HMGB1) impaired cardiac excitation-contraction coupling by enhancing the sarcoplasmic reticulum (SR) $\mathrm{Ca}^{2+}$ leak through TLR4-ROS signaling in cardiomyocytes. J. Mol. Cell. Cardiol. 2014, 74, 260-273. [CrossRef] [PubMed]

474. Zhao, H.; Zhang, M.; Zhou, F.; Cao, W.; Bi, L.; Xie, Y.; Yang, Q.; Wang, S. Cinnamaldehyde ameliorates LPS-induced cardiac dysfunction via TLR4-NOX4 pathway: The regulation of autophagy and ROS production. J. Mol. Cell. Cardiol. 2016, 101, 11-24. [CrossRef] [PubMed]

475. Akoumi, A.; Haffar, T.; Mousterji, M.; Kiss, R.S.; Bousette, N. Palmitate mediated diacylglycerol accumulation causes endoplasmic reticulum stress, Plin2 degradation, and cell death in H9C2 cardiomyoblasts. Exp. Cell Res. 2017, 354, 85-94. [CrossRef] [PubMed]

476. Russo, S.B.; Baicu, C.F.; Van Laer, A.; Geng, T.; Kasiganesan, H.; Zile, M.R.; Cowart, L.A. Ceramide synthase 5 mediates lipid-induced autophagy and hypertrophy in cardiomyocytes. J. Clin. Investig. 2012, 122, 3919-3930. [CrossRef]

477. Butler, T.; Ashford, D.; Seymour, A.-M. Western diet increases cardiac ceramide content in healthy and hypertrophied hearts. Nutr. Metab. Cardiovasc. Dis. 2017, 27, 991-998. [CrossRef]

478. Colin-Ramirez, E.; Castillo-Martinez, L.; Orea-Tejeda, A.; Zheng, Y.; Westerhout, C.M.; Ezekowitz, J.A. Dietary fatty acids intake and mortality in patients with heart failure. Nutrition 2014, 30, 1366-1371. [CrossRef] [PubMed]

479. Yamagishi, K.; Nettleton, J.A.; Folsom, A.R. Plasma fatty acid composition and incident heart failure in middle-aged adults: The Atherosclerosis Risk in Communities (ARIC) Study. Am. Heart J. 2008, 156, 965-974. [CrossRef]

480. Esselstyn, C.B.; Ellis, S.G., Jr.; Medendorp, S.V.; Crowe, T.D. A strategy to arrest and reverse coronary artery disease: A 5-year longitudinal study of a single physician's practice. J. Fam. Pract. 1995, 41, 560-568. [PubMed]

481. Esselstyn, C.B. A plant-based diet and coronary artery disease: A mandate for effective therapy. J. Geriatr. Cardiol. 2017, 14, 317-320.

482. Esselstyn, C.B., Jr. Updating a 12-year experience with arrest and reversal therapy for coronary heart disease (an overdue req-uiem for palliative cardiology). Am. J. Cardiol. 1999, 84, 339-341. [CrossRef]

483. Mccarty, M.F.; DiNicolantonio, J.J. Bioavailable dietary phosphate, a mediator of cardiovascular disease, may be decreased with plant-based diets, phosphate binders, niacin, and avoidance of phosphate additives. Nutrition 2014, 30, 739-747. [CrossRef]

484. Mccarty, M.F. Plant-based diets relatively low in bioavailable phosphate and calcium may aid prevention and control of prostate cancer by lessening production of fibroblast growth factor 23. Med. Hypotheses 2017, 99, 68-72. [CrossRef]

485. Giachelli, C.M. The emerging role of phosphate in vascular calcification. Kidney Int. 2009, 75, 890-897. [CrossRef] [PubMed] 
486. Ferro, C.J.; Chue, C.D.; Steeds, R.P.; Townend, J.N. Is lowering phosphate exposure the key to preventing arterial stiffening with age? Heart 2009, 95, 1770-1772. [CrossRef] [PubMed]

487. Ellam, T.J.; Chico, T.J. Phosphate: The new cholesterol? The role of the phosphate axis in non-uremic vascular disease. Atherosclerosis 2012, 220, 310-318. [CrossRef] [PubMed]

488. Mccarty, M.F.; DiNicolantonio, J.J. The Molecular Biology and Pathophysiology of Vascular Calcification. Postgrad. Med. 2014, 126, 54-64. [CrossRef]

489. Gutiérrez, O.M.; Wolf, M.; Taylor, E.N. Fibroblast Growth Factor 23, Cardiovascular Disease Risk Factors, and Phosphorus Intake in the Health Professionals Follow-up Study. Clin. J. Am. Soc. Nephrol. 2011, 6, 2871-2878. [CrossRef]

490. Vervloet, M.G.; Van Ittersum, F.J.; Büttler, R.M.; Heijboer, A.C.; Blankenstein, M.A.; Ter Wee, P.M. Effects of Dietary Phosphate and Calcium Intake on Fibroblast Growth Factor-23. Clin. J. Am. Soc. Nephrol. 2010, 6, 383-389. [CrossRef]

491. Eckberg, K.; Kramer, H.; Wolf, M.; Durazo-Arvizu, R.; Tayo, B.; Luke, A.; Cooper, R. Impact of westernization on fibroblast growth factor 23 levels among individuals of African ancestry. Nephrol. Dial. Transplant. 2015, 30, 630-635. [CrossRef] [PubMed]

492. Yuen, S.N.; Kramer, H.; Luke, A. Fibroblast Growth Factor-23 (FGF-23) Levels Differ across Populations by Degree of Industrialization. J. Clin. Endocrinol. Metab. 2016, 101, 2246-2253. [CrossRef] [PubMed]

493. Uribarri, J.; Calvo, M.S. Hidden Sources of Phosphorus in the Typical American Diet: Does it Matter in Nephrology? Semin. Dial. 2003, 16, 186-188. [CrossRef]

494. Ritz, E.; Hahn, K.; Ketteler, M.; Kuhlmann, M.K.; Mann, J. Phosphate additives in food-A health risk. Dtsch. Ärzteblatt Int. 2012, 109, 49-55.

495. Fontana, L.; Cummings, N.E.; Apelo, S.I.A. Decreased Consumption of Branched-Chain Amino Acids Improves Metabolic Health. Cell Rep. 2016, 16, 520-530. [CrossRef]

496. McCarty, M.F. GCN2 and FGF21 are likely mediators of the protection from cancer, autoimmunity, obesity, and diabetes afforded by vegan diets. Med. Hypotheses 2014, 83, 365-371. [CrossRef]

497. Castaño-Martinez, T.; Schumacher, F.; Schumacher, S. Methionine restriction prevents onset of type 2 diabetes in NZO mice. FASEB J. 2019, 33, 7092-7102. [CrossRef] [PubMed]

498. De Sousa-Coelho, A.L.; Marrero, P.F.; Haro, D. Activating transcription factor 4-dependent induction of FGF21 during amino acid deprivation. Biochem. J. 2012, 443, 165-171. [CrossRef]

499. Planavila, A.; Redondo, I.; Hondares, E.; Vinciguerra, M.; Munts, C.; Iglesias, R.; Gabrielli, L.A.; Sitges, M.; Giralt, M.; Van Bilsen, M.; et al. Fibroblast growth factor 21 protects against cardiac hypertrophy in mice. Nat. Commun. 2013, 4, 2019. [CrossRef]

500. Planavila, A.; Redondo-Angulo, I.; Ribas, F.; Garrabou, G.; Casademont, J.; Giralt, M.; Villarroya, F. Fibroblast growth factor 21 protects the heart from oxidative stress. Cardiovasc. Res. 2014, 106, 19-31. [CrossRef] [PubMed]

501. Joki, Y.; Ohashi, K.; Yuasa, D.; Shibata, R.; Ito, M.; Matsuo, K.; Kambara, T.; Uemura, Y.; Hayakawa, S.; Hiramatsu-Ito, M.; et al. FGF21 attenuates pathological myocardial remodeling following myocardial infarction through the adiponectin-dependent mechanism. Biochem. Biophys. Res. Commun. 2015, 459, 124-130. [CrossRef]

502. Planavila, A.; Redondo-Angulo, I.; Villarroya, F. FGF21 and Cardiac Physiopathology. Front. Endocrinol. 2015, 6, 133. [CrossRef] [PubMed]

503. Liang, P.; Zhong, L.; Gong, L. Fibroblast growth factor 21 protects rat cardiomyocytes from endoplasmic reticulum stress by promoting the fibroblast growth factor receptor 1-extracellular signalregulated kinase 1/2 signaling pathway. Int. J. Mol. Med. 2017, 40, 1477-1485. [CrossRef]

504. Zhang, Y.; Xie, Y.; Berglund, E.D.; Coate, K.C.; He, T.T.; Katafuchi, T.; Xiao, G.; Potthoff, M.J.; Wei, W.; Wan, Y.; et al. The starvation hormone, fibroblast growth factor-21, extends lifespan in mice. eLife 2012, 1, e00065. [CrossRef]

505. Mendelsohn, A.R.; Larrick, J.W. Fibroblast Growth Factor-21 Is a Promising Dietary Restriction Mimetic. Rejuvenation Res. 2012, 15, 624-628. [CrossRef]

506. Salminen, A.; Kaarniranta, K.; Kauppinen, A. Regulation of longevity by FGF21: Interaction between energy metabolism and stress responses. Ageing Res. Rev. 2017, 37, 79-93. [CrossRef]

507. Willcox, B.J.; Willcox, D.C.; Todoriki, H. Caloric restriction, the traditional Okinawan diet, and healthy aging: The diet of the world's longest-lived people and its potential impact on morbidity and life span. Ann. N. Y. Acad. Sci. 2007, 1114, 434-455. [CrossRef]

508. Mccarty, M.F.; Barroso-Aranda, J.; Contreras, F. The low-methionine content of vegan diets may make methionine restriction feasible as a life extension strategy. Med. Hypotheses 2009, 72, 125-128. [CrossRef] [PubMed]

509. Wek, R.C.; Jiang, H.Y.; Anthony, T.G. Coping with stress: eIF2 kinases and translational control. Biochem. Soc. Trans. 2006, 34 Pt 1 , 7-11. [CrossRef]

510. Boyce, M.; Bryant, K.F.; Jousse, C.; Long, K.; Harding, H.P.; Scheuner, D.; Kaufman, R.J.; Ma, D.; Coen, D.M.; Ron, D.; et al. A Selective Inhibitor of eIF2 Dephosphorylation Protects Cells from ER Stress. Science 2005, 307, 935-939. [CrossRef] [PubMed]

511. Qin, P.; Arabacilar, P.; Bernard, R.E.; Bao, W.; Olzinski, A.R.; Guo, Y.; Lal, H.; Eisennagel, S.H.; Platchek, M.C.; Xie, W.; et al. Activation of the Amino Acid Response Pathway Blunts the Effects of Cardiac Stress. J. Am. Heart Assoc. 2017, 6, e004453. [CrossRef]

512. Rani, S.; Sreenivasaiah, P.K.; Cho, C.; Kim, D.H. Salubrinal Alleviates Pressure Overload-Induced Cardiac Hypertrophy by Inhibiting Endoplasmic Reticulum Stress Pathway. Mol. Cells 2017, 40, 66-72. [CrossRef] 
513. He, Y.-Y.; Liu, C.-L.; Li, X.; Li, R.-J.; Wang, L.-L.; He, K.-L. Salubrinal attenuates right ventricular hypertrophy and dysfunction in hypoxic pulmonary hypertension of rats. Vasc. Pharmacol. 2016, 87, 190-198. [CrossRef]

514. Liu, Y.; Qi, S.Y.; Ru, L.S. Salubrinal improves cardiac function in rats with heart failure post myocardial infarction through reducing endoplasmic reticulum stress-associated apoptosis. Zhonghua Xin Xue Guan Bing Za Zhi 2016, 44, 494-500.

515. Liu, Y.; Wang, J.; Qi, S.-Y.; Ru, L.-S.; Ding, C.; Wang, H.-J.; Zhao, J.-S.; Li, J.-J.; Li, A.-Y.; Wang, D.-M. Reduced Endoplasmic Reticulum Stress Might Alter the Course of Heart Failure via Caspase-12 and JNK Pathways. Can. J. Cardiol. 2014, 30, 368-375. [CrossRef]

516. Lu, Z.; Xu, X.; Fassett, J.; Kwak, D.; Liu, X.; Hu, X.; Wang, H.; Guo, H.; Xu, D.; Yan, S.; et al. Loss of the eukaryotic initiation factor $2 \alpha$ kinase general control nonderepressible 2 protects mice from pressure overload-induced congestive heart failure without affecting ventricular hypertrophy. Hypertension 2014, 63, 128-135. [CrossRef]

517. Campbell, T.C.; Chen, J. Energy balance: Interpretation of data from rural China. Toxicol. Sci. 1999, 52, 87-94. [CrossRef] [PubMed]

518. Haddad, E.H.; Berk, L.S.; Kettering, J.D.; Hubbard, R.W.; Peters, W.R. Dietary intake and biochemical, hematologic, and immune status of vegans compared with nonvegetarians. Am. J. Clin. Nutr. 1999, 70, 586s-593s. [CrossRef] [PubMed]

519. Spencer, E.A.; Appleby, P.N.; Davey, G.K.; Key, T.J. Diet and body mass index in 38000 EPIC-Oxford meat-eaters, fish-eaters, vegetarians and vegans. Int. J. Obes. 2003, 27, 728-734. [CrossRef]

520. Newby, P.K.; Tucker, K.L.; Wolk, A. Risk of overweight and obesity among semivegetarian, lactovegetarian, and vegan women. Am. J. Clin. Nutr. 2005, 81, 1267-1274. [CrossRef] [PubMed]

521. Tonstad, S.; Butler, T.; Yan, R.; Fraser, G.E. Type of Vegetarian Diet, Body Weight, and Prevalence of Type 2 Diabetes. Diabetes Care 2009, 32, 791-796. [CrossRef]

522. Tonstad, S.; Stewart, K.; Oda, K.; Batech, M.; Herring, R.; Fraser, G. Vegetarian diets and incidence of diabetes in the Adventist Health Study-2. Nutr. Metab. Cardiovasc. Dis. 2013, 23, 292-299. [CrossRef]

523. Dod, H.S.; Bhardwaj, R.; Sajja, V.; Weidner, G.; Hobbs, G.R.; Konat, G.W.; Manivannan, S.; Gharib, W.; Warden, B.E.; Nanda, N.C.; et al. Effect of Intensive Lifestyle Changes on Endothelial Function and on Inflammatory Markers of Atherosclerosis. Am. J. Cardiol. 2010, 105, 362-367. [CrossRef]

524. Mccarty, M.F. A shift in myocardial substrate, improved endothelial function, and diminished sympathetic activity may contribute to the anti-anginal impact of very-low-fat diets. Med. Hypotheses 2004, 62, 62-71. [CrossRef]

525. Hall, W.L. Dietary saturated and unsaturated fats as determinants of blood pressure and vascular function. Nutr. Res. Rev. 2009, 22, 18-38. [CrossRef] [PubMed]

526. Cook, B.; Cooper, D.; Fitzpatrick, D.; Smith, S.; Tierney, D.; Mehy, S. 8:45-90:00. The Influence of a High Fat Meal Compared to an Olestra Meal on Coronary Artery Endothelial Dysfunction by Rubidium (Rb)-82 Positron Emission Tomography (PET) and on Post Prandial Serum Triglycerides. Clin. Positron Imaging 2000, 3, 150. [CrossRef]

527. Tektonidis, T.G.; Åkesson, A.; Gigante, B.; Wolk, A.; Larsson, S.C. A Mediterranean diet and risk of myocardial infarction, heart failure and stroke: A population-based cohort study. Atherosclerosis 2015, 243, 93-98. [CrossRef]

528. Nettleton, J.A.; Steffen, L.M.; Loehr, L.R.; Rosamond, W.D.; Folsom, A.R. Incident Heart Failure Is Associated with Lower Whole-Grain Intake and Greater High-Fat Dairy and Egg Intake in the Atherosclerosis Risk in Communities (ARIC) Study. J. Am. Diet. Assoc. 2008, 108, 1881-1887. [CrossRef]

529. Pfister, R.; Sharp, S.J.; Luben, R.; Wareham, N.J.; Khaw, K.-T. Plasma vitamin C predicts incident heart failure in men and women in European Prospective Investigation into Cancer and Nutrition-Norfolk prospective study. Am. Heart J. 2011, 162, $246-253$. [CrossRef]

530. Ashaye, A.; Gaziano, J.; Djoussé, L. Red meat consumption and risk of heart failure in male physicians. Nutr. Metab. Cardiovasc. Dis. 2011, 21, 941-946. [CrossRef] [PubMed]

531. Wannamethee, S.G.; Bruckdorfer, K.R.; Shaper, A.G.; Papacosta, O.; Lennon, L.; Whincup, P.H. Plasma Vitamin C, but Not Vitamin E, Is Associated with Reduced Risk of Heart Failure in Older Men. Circ. Heart Fail. 2013, 6, 647-654. [CrossRef]

532. Choi, E.Y.; Allen, K.; McDonnough, M.; Massera, D.; Ostfeld, R.J. A plant-based diet and heart failure: Case report and literature review. J. Geriatr. Cardiol. 2017, 14, 375-378. [PubMed]

533. Mccarty, M.F. Sub-optimal taurine status may promote platelet hyperaggregability in vegetarians. Med. Hypotheses 2004, 63, 426-433. [CrossRef] [PubMed]

534. Krajcovicová-Kudlácková, M.; Simoncic, R.; Béderová, A.; Babinská, K.; Béder, I. Correlation of carnitine levels to methionine and lysine intake. Physiol. Res. 2000, 49, 399-402. [PubMed]

535. Fedorova, O.V.; Zernetkina, V.I.; Shilova, V.Y. Synthesis of an Endogenous Steroidal Na Pump Inhibitor Marinobufagenin, Implicated in Human Cardiovascular Diseases, Is Initiated by CYP27A1 via Bile Acid Pathway. Circ. Cardiovasc. Genet. 2015, 8, 736-745. [CrossRef]

536. Fedorova, O.V.; Bagrov, A.Y. Inhibition of Na/K ATPase from rat aorta by two Na/K pump inhibitors, ouabain and marinobufagenin: Evidence of interaction with different alpha-subunit isoforms. Am. J. Hypertens 1997, 10, 929-935. [CrossRef]

537. Elkareh, J.; Kennedy, D.J.; Yashaswi, B.; Vetteth, S.; Shidyak, A.; Kim, E.G.R.; Smaili, S.; Periyasamy, S.M.; Hariri, I.M.; Fedorova, L.; et al. Marinobufagenin Stimulates Fibroblast Collagen Production and Causes Fibrosis in Experimental Uremic Cardiomyopathy. Hypertension 2007, 49, 215-224. [CrossRef]

538. Orlov, S.N.; Klimanova, E.A.; Tverskoi, A.M.; Vladychenskaya, E.A.; Smolyaninova, L.V.; Lopina, O.D. Na+ i, K+ i-dependent and-independent signaling triggered by cardiotonic steroids: Facts and artifacts. Molecules 2017, 22, 635. [CrossRef] 
539. Fedorova, O.V.; Kolodkin, N.I.; Agalakova, N.I.; Lakatta, E.G.; Bagrov, A.Y. Marinobufagenin, an Endogenous $\alpha-1$ Sodium Pump Ligand, in Hypertensive Dahl Salt-Sensitive Rats. Hypertension 2001, 37, 462-466. [CrossRef]

540. Bagrov, A.Y.; Roukoyatkina, N.I.; Pinaev, A.G.; Dmitrieva, R.I.; Fedorova, O.V. Effects of two endogenous Na+,K+-ATPase inhibitors, marinobufagenin and ouabain, on isolated rat aorta. Eur. J. Pharmacol. 1995, 274, 151-158. [CrossRef]

541. Bai, Y.; Morgan, E.E.; Giovannucci, D.R.; Pierre, S.V.; Philipson, K.D.; Askari, A.; Liu, L. Different roles of the cardiac Na ${ }^{+} / \mathrm{Ca}^{2+}{ }_{-}$ exchanger in ouabain-induced inotropy, cell signaling, and hypertrophy. Am. J. Physiol. Circ. Physiol. 2013, 304, H427-H435. [CrossRef] [PubMed]

542. Fedorova, O.V.; Talan, M.I.; Agalakova, N.I.; Lakatta, E.G.; Bagrov, A.Y. Endogenous Ligand of $\alpha 1$ Sodium Pump, Marinobufagenin, Is a Novel Mediator of Sodium Chloride-Dependent Hypertension. Circulation 2002, 105, 1122-1127. [CrossRef]

543. Orlov, S.N.; La, J.; Smolyaninova, L.V.; Dulin, N.O. Na ${ }^{+}, \mathrm{K}^{+}$-ATPase as a Target for Treatment of Tissue Fibrosis. Curr. Med. Chem. 2019, 26, 564-575. [CrossRef]

544. Drummond, C.A.; Hill, M.C.; Shi, H.; Fan, X.; Xie, J.X.; Haller, S.T.; Kennedy, D.J.; Liu, J.; Garrett, M.R.; Xie, Z.; et al. Na /K-ATPase signaling regulates collagen synthesis through microRNA-29b-3p in cardiac fibroblasts. Physiol. Genom. 2016, 48, 220-229. [CrossRef] [PubMed]

545. McCarty, M.F. Marinobufagenin may mediate the impact of salty diets on left ventricular hypertrophy by disrupting the protective function of coronary microvascular endothelium. Med. Hypotheses 2005, 64, 854-863. [CrossRef]

546. Heimann, J.C.; Drumond, S.; Tadeu, A.; Alves, R.; Julio, A.; Barbato, G.; Dichtchekenian, V.; Marcondes, M. Left Ventricular Hypertrophy Is More Marked in Salt-Sensitive than in Salt-Resistant Hypertensive Patients. J. Cardiovasc. Pharmacol. 1991, 17, S122-S124. [CrossRef]

547. de la Sierra, A.; Lluch, M.M.; Pare, J.C. Increased left ventricular mass in salt-sensitive hypertensive patients. J. Hum. Hypertens. 1996, 10, 795-799.

548. Schmieder, R.E.; Messerli, F.H.; Rüddel, H.; Garavaglia, G.G.; Grube, E.; Núñez, B.D.; Schulte, W. Sodium intake modulates left ventricular hypertrophy in essential hypertension. J. Hypertens. 1988, 6, S148-S150. [CrossRef]

549. Beil, A.H.; Schmieder, R.E. Salt intake as a determinant of cardiac hypertrophy. Blood Press. Suppl. 1995, 2, 30-34. [PubMed]

550. Alderman, M.H.; Cohen, H.W. Impact of dietary sodium on cardiovascular disease morbidity and mortality. Curr. Hypertens. Rep. 2002, 4, 453-457. [CrossRef]

551. Mente, A.; O’Donnell, M.; Rangarajan, S.; Dagenais, G.; Lear, S.; McQueen, M.; Diaz, R.; Avezum, A.; Lopez-Jaramillo, P.; Lanas, F.; et al. Associations of urinary sodium excretion with cardiovascular events in individuals with and without hypertension: A pooled analysis of data from four studies. Lancet 2016, 388, 465-475. [CrossRef]

552. MacGregor, G.A.; Markandu, N.D.; Singer, D.R.; Cappuccio, F.P.; Shore, A.C.; Sagnella, G.A. Moderate sodium restriction with angiotensin converting enzyme inhibitor in essential hypertension: A double blind study. BMJ 1987, 294, 531-534. [CrossRef] [PubMed]

553. Penton, D.; Czogalla, J.; Loffing, J. Dietary potassium and the renal control of salt balance and blood pressure. Pflügers Arch. Eur. J. Physiol. 2015, 467, 513-530. [CrossRef]

554. Haring, B.; Wang, W.; Lee, E.T.; Jhamnani, S.; Howard, B.V.; Devereux, R.B. Effect of dietary sodium and potassium intake on left ventricular diastolic function and mass in adults $\leq 40$ years (from the Strong Heart Study). Am. J. Cardiol. 2015, 115, 1244-1248. [CrossRef] [PubMed]

555. Mervaala, E.M.; Paakkari, I.; Laakso, J.; Nevala, R.; Teräväinen, T.M.-L.; Fyhrquist, F.; Vapaatalo, H.; Karppanen, H. Replacement of salt by a novel potassium- and magnesium-enriched salt alternative improves the cardiovascular effects of ramipril. $\mathrm{Br}$. $\mathrm{J}$. Pharmacol. 1994, 111, 1189-1197. [CrossRef]

556. Chang, H.-Y.; Hu, Y.-W.; Yue, C.-S.J.; Wen, Y.-W.; Yeh, W.-T.; Hsu, L.-S.; Tsai, S.-Y.; Pan, W.-H. Effect of potassium-enriched salt on cardiovascular mortality and medical expenses of elderly men. Am. J. Clin. Nutr. 2006, 83, 1289-1296. [CrossRef] [PubMed]

557. Jewiss, D.; Ostman, C.; Smart, N. The effect of resistance training on clinical outcomes in heart failure: A systematic review and meta-analysis. Int. J. Cardiol. 2016, 221, 674-681. [CrossRef]

558. Pearson, M.; Smart, N. Effect of exercise training on endothelial function in heart failure patients: A systematic review metaanalysis. Int. J. Cardiol. 2017, 231, 234-243. [CrossRef] [PubMed]

559. Chan, E.; Giallauria, F.; Vigorito, C.; Smart, N.A. Exercise training in heart failure patients with preserved ejection fraction: A systematic review and meta-analysis. Monaldi Arch. Chest Dis. 2016, 86, 759. [CrossRef]

560. Ferrari, R.; Bachetti, T.; Agnoletti, L.; Comini, L.; Curello, S. Endothelial function and dysfunction in heart failure. Eur. Heart J. 1998, 19, G41-G47.

561. Callaerts-Végh, Z.; Wenk, M.; Goebbels, U.; Dziekan, G.; Myers, J.; Dubach, P.; Haefeli, W.E. Influence of Intensive Physical Training on Urinary Nitrate Elimination and Plasma Endothelin-1 Levels in Patients with Congestive Heart Failure. J. Cardiopulm. Rehabil. 1998, 18, 450-457. [CrossRef] [PubMed]

562. Gielen, S.; Erbs, S.; Schuler, G.; Hambrecht, R. Exercise training and endothelial dysfunction in coronary artery disease and chronic heart failure. From molecular biology to clinical benefits. Minerva Cardioangiol. 2002, 50, 95-106.

563. Blum, N.; Blum, A. Beneficial effects of sauna bathing for heart failure patients. Exp. Clin. Cardiol. 2007, 12, 29-32.

564. Mussivand, T.; Alshaer, H.; Haddad, H. Thermal therapy: A viable adjunct in the treatment of heart failure? Congest. Heart Fail. 2008, 14, 180-186. [CrossRef] 
565. Tei, C.; Imamura, T.; Kinugawa, K.; Inoue, T.; Masuyama, T.; Inoue, H.; Noike, H.; Muramatsu, T.; Takeishi, Y.; Saku, K.; et al. Waon Therapy for Managing Chronic Heart Failure-Results from a Multicenter Prospective Randomized WAON-CHF Study. Circ. J. 2016, 80, 827-834. [CrossRef]

566. Haseba, S.; Sakakima, H.; Kubozono, T.; Nakao, S.; Ikeda, S. Combined effects of repeated sauna therapy and exercise training on cardiac function and physical activity in patients with chronic heart failure. Disabil. Rehabil. 2015, 38, 409-415. [CrossRef]

567. Sobajima, M.; Nozawa, T.; Fukui, Y.; Ihori, H.; Ohori, T.; Fujii, N.; Inoue, H. Waon Therapy Improves Quality of Life as Well as Cardiac Function and Exercise Capacity in Patients with Chronic Heart Failure. Int. Heart J. 2015, 56, 203-208. [CrossRef]

568. Brunt, V.E.; Howard, M.J.; Francisco, M.A.; Ely, B.R.; Minson, C.T. Passive heat therapy improves endothelial function, arterial stiffness and blood pressure in sedentary humans. J. Physiol. 2016, 594, 5329-5342. [CrossRef] [PubMed]

569. Laukkanen, T.; Khan, H.; Zaccardi, F.; Laukkanen, J.A. Association between Sauna Bathing and Fatal Cardiovascular and All-Cause Mortality Events. JAMA Intern. Med. 2015, 175, 542. [CrossRef]

570. Zarezadeh, M.; Faghfouri, A.H.; Radkhah, N.; Foroumandi, E.; Khorshidi, M.; Rasouli, A.; Zarei, M.; Honarvar, N.M.; Karzar, N.H.; Mamaghani, M.E. Spirulina supplementation and anthropometric indices: A systematic review and meta-analysis of controlled clinical trials. Phytother. Res. 2021, 35, 577-586. [CrossRef]

571. Papanas, N.; Ziegler, D. Efficacy of $\alpha$-lipoic acid in diabetic neuropathy. Expert Opin. Pharmacother. 2014, 15, 2721-2731. [CrossRef] [PubMed]

572. Bumrungpert, A.; Lilitchan, S.; Tuntipopipat, S.; Tirawanchai, N.; Komindr, S. Ferulic Acid Supplementation Improves Lipid Profiles, Oxidative Stress, and Inflammatory Status in Hyperlipidemic Subjects: A Randomized, Double-Blind, Placebo-Controlled Clinical Trial. Nutrients 2018, 10, 713. [CrossRef] [PubMed]

573. Zhang, X.X.; Zhao, D.S.; Wang, J. The treatment of cardiovascular diseases: A review of ferulic acid and its derivatives. Pharmazie 2021, 76, 55-60. [PubMed]

574. Prasad, A.S.; Beck, F.W.J.; Bao, B.; Fitzgerald, J.T.; Snell, D.C.; Steinberg, J.D.; Cardozo, L.J. Zinc supplementation decreases incidence of infections in the elderly: Effect of zinc on generation of cytokines and oxidative stress. Am. J. Clin. Nutr. 2007, 85, 837-844. [CrossRef] [PubMed]

575. Di Lorenzo, L.A.; Iannuzzo, G.; Parlato, A. Clinical Evidence for Q10 Coenzyme Supplementation in Heart Failure: From Energetics to Functional Improvement. J. Clin. Med. 2020, 9, 1266. [CrossRef] [PubMed]

576. Alf, D.; Schmidt, M.E.; Siebrecht, S.C. Ubiquinol supplementation enhances peak power production in trained athletes: A doubleblind, placebo controlled study. J. Int. Soc. Sports Nutr. 2013, 10, 24. [CrossRef]

577. Kato, T.; Kasai, T.; Sato, A.; Ishiwata, S.; Yatsu, S.; Matsumoto, H.; Shitara, J.; Murata, A.; Shimizu, M.; Suda, S.; et al. Effects of 3Month Astaxanthin Supplementation on Cardiac Function in Heart Failure Patients with Left Ventricular Systolic Dysfunction-A Pilot Study. Nutrients 2020, 12, 1896. [CrossRef]

578. Xia, W.; Tang, N.; Kord-Varkaneh, H.; Low, T.Y.; Tan, S.C.; Wu, X.; Zhu, Y. The effects of astaxanthin supplementation on obesity, blood pressure, CRP, glycemic biomarkers, and lipid profile: A meta-analysis of randomized controlled trials. Pharmacol. Res. 2020, 161, 105113. [CrossRef]

579. Gandolfi, J.V.; Di Bernardo, A.P.A.; Chanes, D.A.V. The Effects of Melatonin Supplementation on Sleep Quality and Assessment of the Serum Melatonin in ICU Patients: A Randomized Controlled Trial. Crit. Care Med. 2020, 48, e1286-e1293. [CrossRef]

580. Ferlazzo, N.; Andolina, G.; Cannata, A.; Costanzo, M.G.; Rizzo, V.; Currò, M.; Ientile, R.; Caccamo, D. Is Melatonin the Cornucopia of the 21st Century? Antioxidants 2020, 9, 1088. [CrossRef]

581. Kars, M.; Yang, L.; Gregor, M.F.; Mohammed, B.S.; Pietka, T.A.; Finck, B.N.; Patterson, B.W.; Horton, J.D.; Mittendorfer, B.; Hotamisligil, G.S.; et al. Tauroursodeoxycholic Acid May Improve Liver and Muscle but Not Adipose Tissue Insulin Sensitivity in Obese Men and Women. Diabetes 2010, 59, 1899-1905. [CrossRef]

582. Liang, Y.; Xu, X.; Yin, M.; Zhang, Y.; Huang, L.; Chen, R.; Ni, J. Effects of berberine on blood glucose in patients with type 2 diabetes mellitus: A systematic literature review and a meta-analysis. Endocr. J. 2019, 66, 51-63. [CrossRef] [PubMed]

583. Bernasconi, A.A.; Wiest, M.M.; Lavie, C.J.; Milani, R.V.; Laukkanen, J.A. Effect of Omega-3 Dosage on Cardiovascular Outcomes: An Updated Meta-Analysis and Meta-Regression of Interventional Trials. Mayo Clin. Proc. 2021, 96, 304-313. [CrossRef]

584. Dibaba, D.T.; Xun, P.; Song, Y.; Rosanoff, A.; Shechter, M.; He, K. The effect of magnesium supplementation on blood pressure in individuals with insulin resistance, prediabetes, or noncommunicable chronic diseases: A meta-analysis of randomized controlled trials. Am. J. Clin. Nutr. 2017, 106, 921-929. [CrossRef]

585. Shatanawi, A.; Momani, M.S.; Al-Aqtash, R.; Hamdan, M.H.; Gharaibeh, M.N. L-Citrulline Supplementation Increases Plasma Nitric Oxide Levels and Reduces Arginase Activity in Patients with Type 2 Diabetes. Front. Pharmacol. 2020, 11, 584669. [CrossRef] [PubMed]

586. Rashid, J.; Kumar, S.S.; Job, K.M.; Liu, X.; Fike, C.D.; Sherwin, C.M.T. Therapeutic Potential of Citrulline as an Arginine Supplement: A Clinical Pharmacology Review. Pediatr. Drugs 2020, 22, 279-293. [CrossRef] [PubMed]

587. Jonvik, K.L.; Nyakayiru, J.; Pinckaers, P.J.; Senden, J.M.; Van Loon, L.J.; Verdijk, L.B. Nitrate-Rich Vegetables Increase Plasma Nitrate and Nitrite Concentrations and Lower Blood Pressure in Healthy Adults. J. Nutr. 2016, 146, 986-993. [CrossRef]

588. Woessner, M.N.; Levinger, I.; Allen, J.D.; McIlvenna, L.C.; Neil, C. The Effect of Dietary Inorganic Nitrate Supplementation on Cardiac Function during Submaximal Exercise in Men with Heart Failure with Reduced Ejection Fraction (HFrEF): A Pilot Study. Nutrients 2020, 12, 2132. [CrossRef] [PubMed] 
589. Koutsikos, D.; Agroyannis, B.; Tzanatos-Exarchou, H. Biotin for diabetic peripheral neuropathy. Biomed. Pharmacother. 1990, 44, 511-514. [CrossRef]

590. McCarty, M.F. In type 1 diabetics, high-dose biotin may compensate for low hepatic insulin exposure, promoting a more normal expression of glycolytic and gluconeogenic enyzymes and thereby aiding glycemic control. Med. Hypotheses 2016, 95, 45-48. [CrossRef]

591. De Gregorio, G.C.; Marini, H.; Alibrandi, A. Genistein Supplementation and Cardiac Function in Postmenopausal Women with Metabolic Syndrome: Results from a Pilot Strain-Echo Study. Nutrients 2017, 9, 584. [CrossRef]

592. D'Anna, R.; Cannata, M.L.; Marini, H. Effects of the phytoestrogen genistein on hot flushes, endometrium, and vaginal epithelium in postmenopausal women: A 2-year randomized, double-blind, placebo-controlled study. Menopause 2009, 16, 301-306. [CrossRef]

593. Heiss, C.; Finis, D.; Kleinbongard, P.; Hoffmann, A.; Rassaf, T.; Kelm, M.; Sies, H. Sustained Increase in Flow-Mediated Dilation after Daily Intake of High-Flavanol Cocoa Drink over 1 Week. J. Cardiovasc. Pharmacol. 2007, 49, 74-80. [CrossRef]

594. Ried, K.; Fakler, P.; Stocks, N.P. Effect of cocoa on blood pressure. Cochrane Database Syst. Rev. 2017, 4, CD008893. [CrossRef]

595. Sandoval, G.C.; Santillan, R.M.; Juarez, E.; Martlnez, G.R.; Juärez, M.E.C. Effect of glycine on hemoglobin glycation in diabetic patients. In Proceedings of the Western Pharmacology Society, Maui, HI, USA, 30 January-4 February 1999; Volume 42, pp. 31-32.

596. Cruz, M.; Maldonado-Bernal, C.; Mondragon-Gonzalez, R. Glycine treatment decreases proinflammatory cytokines and increases interferon-gamma in patients with type 2 diabetes. J. Endocrinol. Investig. 2008, 31, 694-699. [CrossRef]

597. Rojas-Sobarzo, L.; Olivares, M.; Brito, A.; Suazo, M.; Araya, M.; Pizarro, F. Copper Supplementation at 8 mg Neither Affects Circulating Lipids nor Liver Function in Apparently Healthy Chilean Men. Biol. Trace Elem. Res. 2013, 156, 1-4. [CrossRef]

598. Witte, K.K.; Clark, A.L. Micronutrients and their supplementation in chronic cardiac failure. An update beyond theoretical perspectives. Heart Fail. Rev. 2006, 11, 65-74. [CrossRef]

599. Cicero, A.F.; Colletti, A. Nutraceuticals and Dietary Supplements to Improve Quality of Life and Outcomes in Heart Failure Patients. Curr. Pharm. Des. 2017, 23, 1265-1272. [CrossRef]

600. Jeejeebhoy, F.; Keith, M.; Freeman, M. Nutritional supplementation with MyoVive repletes essential cardiac myocyte nutrients and reduces left ventricular size in patients with left ventricular dysfunction. Am. Heart J. 2002, 143, 1092-1100. [CrossRef]

601. Mccarty, M.F. Fish oil and other nutritional adjuvants for treatment of congestive heart failure. Med. Hypotheses 1996, 46, 400-406. [CrossRef]

602. Pastori, D.; Pignatelli, P.; Carnevale, R.; Violi, F. Nox-2 up-regulation and platelet activation: Novel insights. Prostaglandins Other Lipid Mediat. 2015, 120, 50-55. [CrossRef] [PubMed]

603. Sun, Q.-A.; Madamanchi, N.R.; Runge, M.S. Oxidative stress, NADPH oxidases, and arteries. Hämostaseologie 2016, 36, 77-88. [CrossRef] [PubMed]

604. Quesada, I.; Lucero, A.; Amaya, C.; Meijles, D.; Cifuentes, M.; Pagano, P.; Castro, C. Selective inactivation of NADPH oxidase 2 causes regression of vascularization and the size and stability of atherosclerotic plaques. Atherosclerosis 2015, 242, 469-475. [CrossRef]

605. Azumi, H.; Inoue, N.; Ohashi, Y. Superoxide generation in directional coronary atherectomy specimens of patients with angina pectoris: Important role of NAD(P)H oxidase. Arterioscler. Thromb. Vasc. Biol. 2002, 22, 1838-1844. [CrossRef]

606. Xu, S.; Chamseddine, A.H.; Carrell, S.; Miller, F.J. Nox4 NADPH oxidase contributes to smooth muscle cell phenotypes associated with unstable atherosclerotic plaques. Redox Biol. 2014, 2, 642-650. [CrossRef] [PubMed]

607. Peng, J.-J.; Liu, B.; Xu, J.-Y.; Peng, J.; Luo, X.-J. NADPH oxidase: Its potential role in promotion of pulmonary arterial hypertension. Naunyn Schmiedeberg's Arch. Pharmacol. 2017, 390, 331-338. [CrossRef]

608. Paravicini, T.M.; Touyz, R.M. NADPH Oxidases, Reactive Oxygen Species, and Hypertension: Clinical implications and therapeutic possibilities. Diabetes Care 2008, 31, S170-S180. [CrossRef]

609. Guzik, B.; Sagan, A.; Ludew, D.; Mrowiecki, W.; Chwała, M.; Bujak-Gizycka, B.; Filip, G.; Grudzien, G.; Kapelak, B.; Żmudka, K.; et al. Mechanisms of oxidative stress in human aortic aneurysms-Association with clinical risk factors for atherosclerosis and disease severity. Int. J. Cardiol. 2013, 168, 2389-2396. [CrossRef]

610. Xiong, W.; MacTaggart, J.N.; Knispel, R.; Worth, J.M.; Zhu, Z.; Li, Y.; Sun, Y.; Baxter, B.T.; Johanning, J.M. Inhibition of reactive oxygen species attenuates aneurysm formation in a murine model. Atherosclerosis 2009, 202, 128-134. [CrossRef] [PubMed]

611. Tada, Y.; Yano, S.; Yamaguchi, T.; Okazaki, K.; Ogawa, N.; Morita, M.; Sugimoto, T. Advanced Glycation End Products-induced Vascular Calcification is Mediated by Oxidative Stress: Functional Roles of NAD(P)H-oxidase. Horm. Metab. Res. 2012, 45, 267-272. [CrossRef]

612. Yamada, S.; Taniguchi, M.; Tokumoto, M.; Toyonaga, J.; Fujisaki, K.; Suehiro, T.; Noguchi, H.; Iida, M.; Tsuruya, K.; Kitazono, $\mathrm{T}$. The antioxidant tempol ameliorates arterial medial calcification in uremic rats: Important role of oxidative stress in the pathogenesis of vascular calcification in chronic kidney disease. J. Bone Miner. Res. 2012, 27, 474-485. [CrossRef]

613. De Silva, T.M.; Miller, A.A. Cerebral Small Vessel Disease: Targeting Oxidative Stress as a Novel Therapeutic Strategy? Front. Pharmacol. 2016, 7, 61. [CrossRef]

614. Huang, A.; Young, T.L.; Dang, V.T.; Shi, Y.; McAlpine, C.S.; Werstuck, G.H. 4-phenylbutyrate and valproate treatment attenuates the progression of atherosclerosis and stabilizes existing plaques. Atherosclerosis 2017, 266, 103-112. [CrossRef]

615. Ivanova, E.A.; Orekhov, A.N. The Role of Endoplasmic Reticulum Stress and Unfolded Protein Response in Atherosclerosis. Int. J. Mol. Sci. 2016, 17, 193. [CrossRef] 
616. Tsukano, H.; Gotoh, T.; Endo, M.; Miyata, K.; Tazume, H.; Kadomatsu, T.; Yano, M.; Iwawaki, T.; Kohno, K.; Araki, K.; et al. The Endoplasmic Reticulum Stress-C/EBP Homologous Protein Pathway-Mediated Apoptosis in Macrophages Contributes to the Instability of Atherosclerotic Plaques. Arterioscler. Thromb. Vasc. Biol. 2010, 30, 1925-1932. [CrossRef]

617. Furmanik, M.; Shanahan, C.M. Endoplasmic reticulum stress in arterial smooth muscle cells: A novel regulator of vascular disease. Curr. Cardiol. Rev. 2017, 13, 94-105.

618. Jia, L.X.; Zhang, W.M.; Zhang, H.J. Mechanical stretch-induced endoplasmic reticulum stress, apoptosis and inflammation contribute to thoracic aortic aneurysm and dissection. J. Pathol. 2015, 236, 373-383. [CrossRef]

619. Wu, Y.; Adi, D.; Long, M. 4-Phenylbutyric Acid Induces Protection against Pulmonary Arterial Hypertension in Rats. PLoS ONE 2016, 11, e0157538. [CrossRef]

620. Dromparis, P.; Paulin, R.; Stenson, T.H.; Haromy, A.; Sutendra, G.; Michelakis, E.D. Attenuating Endoplasmic Reticulum Stress as a Novel Therapeutic Strategy in Pulmonary Hypertension. Circulation 2013, 127, 115-125. [CrossRef]

621. Young, C.N. Endoplasmic reticulum stress in the pathogenesis of hypertension. Exp. Physiol. 2017, 102, 869-884. [CrossRef]

622. Förstermann, U. Nitric oxide and oxidative stress in vascular disease. Pflügers Arch. Eur. J. Physiol. 2010, 459, 923-939. [CrossRef] [PubMed]

623. Li, H.; Förstermann, U. Uncoupling of endothelial NO synthase in atherosclerosis and vascular disease. Curr. Opin. Pharmacol. 2013, 13, 161-167. [CrossRef] [PubMed]

624. Gielis, J.F.; Lin, J.Y.; Wingler, K.; Van Schil, P.E.; Schmidt, H.H.; Moens, A.L. Pathogenetic role of eNOS uncoupling in cardiopulmonary disorders. Free Radic. Biol. Med. 2011, 50, 765-776. [CrossRef]

625. Bakker, J.R.; Bondonno, N.P.; Gaspari, T.A. Low dose dietary nitrate improves endothelial dysfunction and plaque stability in the ApoE(-/-) mouse fed a high fat diet. Free Radic. Biol. Med. 2016, 99, 189-198. [CrossRef]

626. Jaitovich, A.; Jourd'Heuil, D. A Brief Overview of Nitric Oxide and Reactive Oxygen Species Signaling in Hypoxia-Induced Pulmonary Hypertension. Adv. Exp. Med. Biol. 2017, 967, 71-81. [CrossRef]

627. Wang, Z.-J.; Wu, J.; Guo, W.; Zhu, Y.-Z. Atherosclerosis and the Hydrogen Sulfide Signaling Pathway-Therapeutic Approaches to Disease Prevention. Cell. Physiol. Biochem. 2017, 42, 859-875. [CrossRef] [PubMed]

628. Meng, G.; Ma, Y.; Xie, L.; Ferro, A.; Ji, Y. Emerging role of hydrogen sulfide in hypertension and related cardiovascular diseases. Br. J. Pharmacol. 2015, 172, 5501-5511. [CrossRef]

629. Yu, X.-H.; Cui, L.-B.; Wu, K.; Zheng, X.-L.; Cayabyab, F.S.; Chen, Z.-W.; Tang, C.-K. Hydrogen sulfide as a potent cardiovascular protective agent. Clin. Chim. Acta 2014, 437, 78-87. [CrossRef]

630. Mani, S.; Untereiner, A.; Wu, L.; Wang, R. Hydrogen Sulfide and the Pathogenesis of Atherosclerosis. Antioxid. Redox Signal. 2014, 20, 805-817. [CrossRef]

631. Brampton, J.; Aaronson, P.I. Role of Hydrogen Sulfide in Systemic and Pulmonary Hypertension: Cellular Mechanisms and Therapeutic Implications. Cardiovasc. Hematol. Agents Med. Chem. 2016, 14, 4-22. [CrossRef] [PubMed]

632. Yang, R.; Teng, X.; Li, H.; Xue, H.-M.; Guo, Q.; Xiao, L.; Wu, Y.-M. Hydrogen Sulfide Improves Vascular Calcification in Rats by Inhibiting Endoplasmic Reticulum Stress. Oxidative Med. Cell. Longev. 2016, 2016, 9095242. [CrossRef]

633. Emerson, M. Hydrogen Sulfide and Platelets: A Possible Role in Thrombosis. Handb. Exp. Pharmacol. 2015, $230,153-162$. [PubMed]

634. Kieboom, B.C.T.; Niemeijer, M.N.; Leening, M.J.G.; Berg, M.E.V.D.; Franco, O.H.; Deckers, J.W.; Hofman, A.; Zietse, R.; Stricker, B.H.; Hoorn, E.J. Serum Magnesium and the Risk of Death from Coronary Heart Disease and Sudden Cardiac Death. J. Am. Heart Assoc. 2016, 5, e002707. [CrossRef] [PubMed]

635. Shechter, M.; Merz, C.B.; Paul-Labrador, M.; Meisel, S.R.; Rude, R.K.; Molloy, M.D.; Dwyer, J.H.; Shah, P.K.; Kaul, S. Oral magnesium supplementation inhibits platelet-dependent thrombosis in patients with coronary artery disease. Am. J. Cardiol. 1999, 84, 152-156. [CrossRef]

636. Posadas-Sánchez, R.; Posadas-Romero, C.; Cardoso-Saldaña, G.; Vargas-Alarcón, G.; Villarreal-Molina, M.T.; Pérez-Hernández, N.; Rodríguez-Pérez, J.M.; Medina-Urrutia, A.; Jorge-Galarza, E.; Juárez-Rojas, J.G.; et al. Serum magnesium is inversely associated with coronary artery calcification in the Genetics of Atherosclerotic Disease (GEA) study. Nutr. J. 2015, 15, 1-7. [CrossRef] [PubMed]

637. Han, C.Y. Roles of Reactive Oxygen Species on Insulin Resistance in Adipose Tissue. Diabetes Metab. J. 2016, 40, 272-279. [CrossRef]

638. Den Hartigh, L.J.; Omer, M.; Goodspeed, L. Adipocyte-Specific Deficiency of NADPH Oxidase 4 Delays the Onset of Insulin Resistance and Attenuates Adipose Tissue Inflammation in Obesity. Arterioscler. Thromb. Vasc. Biol. 2017, 37, 466-475. [CrossRef]

639. Khitan, Z.; Harsh, M.; Sodhi, K.; Shapiro, J.I.; Abraham, N.G. HO-1 Upregulation Attenuates Adipocyte Dysfunction, Obesity, and Isoprostane Levels in Mice Fed High Fructose Diets. J. Nutr. Metab. 2014, 2014, 1-13. [CrossRef] [PubMed]

640. Cao, J.; Peterson, S.J.; Sodhi, K.; Vanella, L.; Barbagallo, I.; Rodella, L.F.; Schwartzman, M.L.; Abraham, N.G.; Kappas, A. Heme Oxygenase Gene Targeting to Adipocytes Attenuates Adiposity and Vascular Dysfunction in Mice Fed a High-Fat Diet. Hypertension 2012, 60, 467-475. [CrossRef]

641. Furukawa, S.; Fujita, T.; Shimabukuro, M. Increased oxidative stress in obesity and its impact on metabolic syndrome. J. Clin. Investig. 2004, 114, 1752-1761. [CrossRef]

642. Liu, J.; Dong, H.; Zhang, Y. Bilirubin Increases Insulin Sensitivity by Regulating Cholesterol Metabolism, Adipokines and PPARgamma Levels. Sci. Rep. 2015, 5, 9886. [CrossRef] 
643. Szulinska, M.; Gibas-Dorna, M.; Miller-Kasprzak, E.; Suliburska, J.; Miczke, A.; Walczak-Gałezewska, M.; Stelmach-Mardas, M.; Walkowiak, J.; Bogdanski, P. Spirulina maxima improves insulin sensitivity, lipid profile, and total antioxidant status in obese patients with well-treated hypertension: A randomized double-blind placebo-controlled study. Eur. Rev. Med. Pharmacol. Sci. 2017, 21, 2473-2481.

644. Hozayen, W.G.; Mahmoud, A.M.; Soliman, H.A.; Mostafa, S.R. Spirulina versicolor improves insulin sensitivity and attenuates hyperglycemia-mediated oxidative stress in fructose-fed rats. J. Intercult. Ethnopharmacol. 2016, 5, 57-64. [CrossRef]

645. Ichimura, M.; Kato, S.; Tsuneyama, K.; Matsutake, S.; Kamogawa, M.; Hirao, E.; Miyata, A.; Mori, S.; Yamaguchi, N.; Suruga, K.; et al. Phycocyanin prevents hypertension and low serum adiponectin level in a rat model of metabolic syndrome. Nutr. Res. 2013, 33, 397-405. [CrossRef] [PubMed]

646. Kawasaki, N.; Asada, R.; Saito, A.; Kanemoto, S.; Imaizumi, K. Obesity-induced endoplasmic reticulum stress causes chronic inflammation in adipose tissue. Sci. Rep. 2012, 2, 799. [CrossRef] [PubMed]

647. Ghosh, A.K.; Garg, S.K.; Mau, T.; O’Brien, M.; Liu, J.; Yung, R. Elevated Endoplasmic Reticulum Stress Response Contributes to Adipose Tissue Inflammation in Aging. J. Gerontol. Ser. A Boil. Sci. Med. Sci. 2014, 70, 1320-1329. [CrossRef] [PubMed]

648. Özcan, U.; Yilmaz, E.; Özcan, L.; Furuhashi, M.; Vaillancourt, E.; Smith, R.O.; Görgün, C.Z.; Hotamisligil, G.S. Chemical Chaperones Reduce ER Stress and Restore Glucose Homeostasis in a Mouse Model of Type 2 Diabetes. Science 2006, 313, 1137-1140. [CrossRef]

649. Guo, Q.; Xu, L.; Liu, J.; Li, H.; Sun, H.; Wu, S.; Zhou, B. Fibroblast growth factor 21 reverses suppression of adiponectin expression via inhibiting endoplasmic reticulum stress in adipose tissue of obese mice. Exp. Biol. Med. 2017, 242, 441-447. [CrossRef] [PubMed]

650. Jiao, P.; Ma, J.; Feng, B. FFA-induced adipocyte inflammation and insulin resistance: Involvement of ER stress and IKKbeta pathways. Obesity 2011, 19, 483-491. [CrossRef]

651. Hoffmann, L.S.; Etzrodt, J.; Willkomm, L. Stimulation of soluble guanylyl cyclase protects against obesity by recruiting brown adipose tissue. Nat. Commun. 2015, 6, 7235. [CrossRef] [PubMed]

652. Joffin, N.; Jaubert, A.-M.; Durant, S.; Bastin, J.; De Bandt, J.-P.; Cynober, L.; Moinard, C.; Forest, C.; Noirez, P. Citrulline induces fatty acid release selectively in visceral adipose tissue from old rats. Mol. Nutr. Food Res. 2014, 58, 1765-1775. [CrossRef] [PubMed]

653. Untereiner, A.; Wu, L. Hydrogen Sulfide and Glucose Homeostasis: A Tale of Sweet and the Stink. Antioxid. Redox Signal. 2018, 28, 1463-1482. [CrossRef]

654. Bełtowski, J.; Jamroz-Wiśniewska, A. Hydrogen Sulfide in the Adipose Tissue-Physiology, Pathology and a Target for Pharmacotherapy. Molecules 2016, 22, 63. [CrossRef] [PubMed]

655. Cai, J.; Shi, X.; Wang, H. Cystathionine gamma lyase-hydrogen sulfide increases peroxisome proliferator-activated receptor gamma activity by sulfhydration at $\mathrm{C} 139$ site thereby promoting glucose uptake and lipid storage in adipocytes. Biochim. Biophys. Acta 2016, 1861, 419-429. [CrossRef]

656. Murakami, S. The physiological and pathophysiological roles of taurine in adipose tissue in relation to obesity. Life Sci. 2017, 186, 80-86. [CrossRef]

657. Kandeel, F.R.; Balon, E.; Scott, S.; Nadler, J.L. Magnesium deficiency and glucose metabolism in rat adipocytes. Metabolism 1996, 45, 838-843. [CrossRef]

658. Guerrero-Romero, F.; Jaquez-Chairez, F.O.; Rodríguez-Morán, M. Magnesium in metabolic syndrome: A review based on randomized, double-blind clinical trials. Magnes. Res. 2016, 29, 146-153. [CrossRef]

659. Sarrafzadegan, N.; Khosravi-Boroujeni, H.; Lotfizadeh, M.; Pourmogaddas, A.; Salehi-Abargouei, A. Magnesium status and the metabolic syndrome: A systematic review and meta-analysis. Nutrition 2016, 32, 409-417. [CrossRef] [PubMed]

660. Li, Y.; Wang, P.; Zhuang, Y. Activation of AMPK by berberine promotes adiponectin multimerization in 3T3-L1 adipocytes. FEBS Lett. 2011, 585, 1735-1740. [CrossRef]

661. Chen, J.; Ma, X.; Yang, Y.; Dai, Z.; Wu, Z.; Wu, G. Glycine enhances expression of adiponectin and IL-10 in 3T3-L1 adipocytes without affecting adipogenesis and lipolysis. Amino Acids 2018, 50, 629-640. [CrossRef]

662. López, Y.R.; Pérez-Torres, I.; Zúñiga-Muñoz, A.; Lans, V.G.; Díaz-Díaz, E.; Castro, E.S.; Espejel, R.V. Effect of Glycine on Adipocyte Hypertrophy in a Metabolic Syndrome Rat Model. Curr. Drug Deliv. 2016, 13, 158-169. [CrossRef]

663. Blancas-Flores, G.; Alarcon-Aguilar, F.J.; Garcia-Macedo, R. Glycine suppresses TNF-alpha-induced activation of NF-kappaB in differentiated 3T3-L1 adipocytes. Eur. J. Pharmacol. 2012, 689, 270-277. [CrossRef] [PubMed]

664. BonDurant, L.D.; Ameka, M.; Naber, M.C.; Markan, K.R.; Idiga, S.O.; Acevedo, M.R.; Walsh, S.A.; Ornitz, D.M.; Potthoff, M.J. FGF21 Regulates Metabolism through Adipose-Dependent and -Independent Mechanisms. Cell Metab. 2017, 25, 935-944.e4. [CrossRef]

665. Giralt, M.; Gavaldà-Navarro, A.; Villarroya, F. Fibroblast growth factor-21, energy balance and obesity. Mol. Cell. Endocrinol. 2015, 418, 66-73. [CrossRef] [PubMed]

666. Turner-McGrievy, G.; Harris, M. Key Elements of Plant-Based Diets Associated with Reduced Risk of Metabolic Syndrome. Curr. Diabetes Rep. 2014, 14, 524. [CrossRef]

667. Roberts, C.K.; Hevener, A.L.; Barnard, R.J. Metabolic Syndrome and Insulin Resistance: Underlying Causes and Modification by Exercise Training. Compr. Physiol. 2013, 3, 1-58. [CrossRef]

668. Kong, W.; Wei, J.; Abidi, P. Berberine is a novel cholesterol-lowering drug working through a unique mechanism distinct from statins. Nat. Med. 2004, 10, 1344-1351. [CrossRef] 
669. Kong, W.-J.; Wei, J.; Zuo, Z.-Y.; Wang, Y.-M.; Song, D.-Q.; You, X.-F.; Zhao, L.-X.; Pan, H.-N.; Jiang, J.-D. Combination of simvastatin with berberine improves the lipid-lowering efficacy. Metabolism 2008, 57, 1029-1037. [CrossRef]

670. Mccarty, M.F.; O’Keefe, J.H.; DiNicolantonio, J.J. Red Yeast Rice Plus Berberine: Practical Strategy for Promoting Vascular and Metabolic Health. Altern. Ther. Health Med. 2015, 21, 40-45. 